\author{
UNIVERSIDADE DE SÃO PAULO \\ PROGRAMA DE PÓS-GRADUAÇÃO EM ENERGIA
}

EDNALDO JOSÉ SILVA DE CAMARGO

PROGRAMA LUZ PARA TODOS - DA ELETRIFICAÇÃO RURAL À UNIVERSALIZAÇÃO DO ACESSO À ENERGIA ELÉTRICA - DA NECESSIDADE DE UMA POLÍTICA DE ESTADO 


\title{
PROGRAMA LUZ PARA TODOS - DA ELETRIFICAÇÃO RURAL À UNIVERSALIZAÇÃO DO ACESSO À ENERGIA ELÉTRICA. DA NECESSIDADE DE UMA POLÍTICA DE ESTADO
}

\author{
Dissertação apresentada ao Programa de Pós- \\ Graduação em Energia da Universidade de São \\ Paulo (Escola Politécnica / Faculdade de \\ Economia e Administração / Instituto de \\ Eletrotécnica e Energia / Instituto de Física) \\ para a obtenção do título de Mestre em \\ Energia.
}

Orientador: Prof. Dr. Fernando Selles Ribeiro

São Paulo

2010 


\section{UNIVERSIDADE DE SÃO PAULO PROGRAMA DE PÓS-GRADUAÇÃO EM ENERGIA EP - FEA - IEE - IF \\ EDNALDO JOSE SILVA DE CAMARGO}

"Programa luz para todos - da eletrificação rural ù universalização do acesso à energia elétrica - da necessidade de uma política de Estado"

Dissertação defendida e aprovada em 20/04/2010 pela Comissão Julgadora:

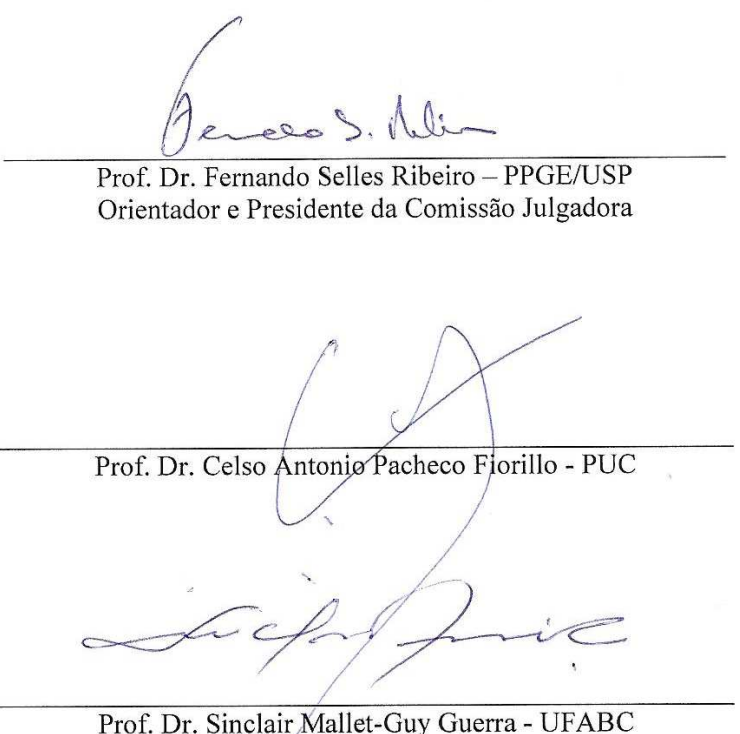

Prof. Dr. Sinclair Mallet-Guy Guerra - UFABC 
AUTORIZO A REPRODUÇÃO E DIVULGAÇÃO TOTAL OU PARCIAL DESTE TRABALHO, POR QUALQUER MEIO CONVENCIONAL OU ELETRÔNICO, PARA FINS DE ESTUDO E PESQUISA, DESDE QUE CITADA A FONTE.

Camargo, Ednaldo José Silva de

Programa Luz para Todos : da eletrificação rural à universalização do acesso à energia elétrica. da necessidade de uma política de estado. / Ednaldo José Silva de Camargo; Orientador: Fernando Selles Ribeiro - São Paulo, 2010.

$131 \mathrm{p}$.

Dissertação (Mestrado) - Programa de Pós-Graduação em Energia -IEE/EP/IF/FEA da Universidade de São Paulo

1. Eletrificação rural 2. Energia elétrica 3. Políticas sociais I. Título 
À minha esposa, Mariza, por acompanhar e confiar. Às minhas filhas Marina e Lígia, por renovarem meus dias. À minha mãe, Deborah (in memorian), e ao meu pai, José, pelo que eu sou. 
Antes de tudo agradeço aos meus companheiros de trabalho no Programa Luz para Todos:

Adriano, Canholi, Carlinhos, Cláudio, Daline, Gabriel, Mari, Perez, Ronaldo e Shinji;

Aos colegas do escritório de Furnas São Paulo - ESP-G

Aos colegas de IEE, Cláudio, Carlos e em especial ao Eduardo Daniel, que passou para o rol dos amigos, e a quem tenho muito a agradecer por ter chegado até aqui.

Aos Professores todos, em especial à Professora Patrícia Matai.

Ao amigo Lucas Buzato, que é parte desta história.

Ao meu orientador Fernando Selles Ribeiro, por não ter medo de proclamar sua paixão pela eletrificação rural. Nós sabemos como foi chegar até aqui.

Aos encontros que a vida proporciona.

Um agradecimento especial a todo povo brasileiro, que, aos poucos, vai aprendendo e ensinando a transformar este País. 
"é preciso que a pesquisa orientada por um paradigma seja um meio particularmente eficaz de induzir a mudanças nesses mesmos paradigmas que a orientam (...) sua assimilação requer a elaboração de um novo conjunto. Depois que elas se incorporam à ciência, o empreendimento científico nunca mais é o mesmo" (THOMAS S. KUHN - 1975)

Nestas vésperas de civilização emergente, o Brasil, que fracassou frente à civilização industrial, tem que ousar no pensamento e na ação. Só alcançaremos êxito - e dele dependerá até mesmo nossa soberania - se tivermos os olhos abertos para a nossa realidade, dentro da realidade de um mundo que nos é indiferente ou hostil; se tivermos o coração aceso para as dores da pobreza dos homens e mulheres de nossa terra; se fizermos nossas as suas mal-fundadas esperanças de felicidade."

(DARCY RIBEIRO - 1992) 


\section{RESUMO}

CAMARGO, Ednaldo J. S. Programa Luz para Todos: da eletrificação rural à universalização do acesso à energia elétrica. da necessidade de uma política de Estado, 2010, 131 f. Dissertação (Mestrado em Energia) - Programa de Pós-Graduação em Energia da Universidade de São Paulo, São Paulo, 2010

A criação do Programa Luz para Todos, em 11 de novembro de 2003, por meio da Lei 10.762, e sua regulamentação pelo Decreto $\mathrm{n}^{\circ} 4.873$, da mesma data, trouxe novos temas para o âmbito do estudo da eletrificação rural. O Programa Luz para Todos acumulou em sua estruturação uma somatória de conhecimentos e experiências anteriores, com um arranjo financeiro que possibilitou uma solução até então inédita para o atendimento do morador pobre das áreas rurais: a total gratuidade da ligação. Essa solução foi possível graças a um arranjo financeiro que envolveu diversas partes. $\mathrm{O}$ Governo Federal, com recursos de dois fundos setoriais: a RGR - Reserva Global de Reversão e a CDE - Conta de Desenvolvimento Energético, sendo a CDE lançada a fundo perdido, como subvenção e a RGR na forma de financiamento, os Governos Estaduais e os agentes concessionários e permissionários, sem qualquer participação financeira por parte do consumidor a ser ligado. Esse arranjo tripartite varia dependendo do impacto tarifário que a ligação ou conjunto de ligações gerar para o agente executor da obra. Assim, eventualmente o percentual de CDE pode ser superior ao da RGR ou mesmo o valor do governo do Estado pode ser igual ao da CDE. Essa estrutura de custo viabilizou em pouco mais de seis anos a ligação de mais de dois milhões e cem mil domicílios muitos dos quais poderiam ser atendidos de outra forma, pois que mais de $60 \%$ desses atendimentos foram em famílias com renda familiar inferior a um salário mínimo. O problema que se coloca é que o Programa tem prazo para acabar: 31 de dezembro de 2.010 e o quadro que se vislumbra é o retorno às normas anteriores ao Programa, que possuem viés excludente. O principal problema apontado é o retorno às normas da Resolução $n^{\circ} 456$, de 29 de novembro de 2000. Essa regulação estabelece que o atendimento da concessionária se dê até o limite da propriedade, decorrendo que, a partir desse ponto, todos os custos serão suportados pelo consumidor que solicitou o serviço. Durante a vigência do Programa Luz para Todos essas normas estiveram suspensas para as ligações efetuadas sob a égide do Programa, pois o Decreto que regulamentou a Lei que criou o Programa efetuou uma transferência de titularidade normativa, determinando que o Ministério de Minas e Energia criaria um Manual de Operacionalização com as normas para a efetivação do Programa. Desse modo houve a suspensão da aplicabilidade das normas que fossem conflitantes com o Manual de Operacionalização. Com o fim do Programa e o retorno do quadro regulatório anterior prevê-se uma situação de exclusão, pelo que são propostas alterações normativas para transformar o que é Programa de Governo em Política de Estado para, assim, garantir que as futuras gerações não sejam vítimas de um sistema elétrico baseado na exclusão dos moradores pobres das áreas rurais..

Palavras-chave: Eletrificação Rural, Universalização do Acesso à Energia Elétrica, Programa Luz para Todos. 


\begin{abstract}
CAMARGO, Ednaldo J. S. Luz para Todos : from rural electrification to universal access to electricity. the need for a state policy, 2010, 131 p. Master's Dissertation Graduate Program on energy, Universidade de São Paulo, 2010

The creation of Luz para Todos Program, at November, 11, 2003, through Law 10.762, and its regulation by Decree 4.873, at the same day, brought new themes for the study of rural electrification. The Luz para Todos Program accumulated in their structure a sum of knowledge and previous experience with a financial solution that enabled a hitherto unprecedented solution for meeting the resident poor rural areas: a totally free connection. This solution was possible through a financial arrangement involving various parties. The Federal Government, with funds from two sector funds - RGR Reserve Global Reversion and CDE - Energy Development Account, CDE released the grant and RGR in the form of funding, the state governments and agents dealers and authorized the absence of any contribution of the consumer to be connected. This tripartite arrangement varied depending on the tariff impact that the connection or set of links would generate for the executive agent of the work, so eventually the percentage of $\mathrm{CDE}$ could be higher than the RGR or the value of the state government could be equal to the CDE. This cost structure made possible in just over six years the connection of more than two million one hundred thousand homes, many of which could never be met otherwise, for more than $60 \%$ of these visits were in families with income less than minimum wage. The problem that arises is that the program has a term to end: December 31, 2010 and the picture that is emerging is the return to the pre program regulations that are exclusionary. The main problem cited is return to the norms of Resolution 456 of 29 November 2000. This regulation requires the attendance of the licensee is given to the extent of the property, with the result that, from that point, all costs are borne by the consumer who requested the service. During the term of Luz para Todos Program these rules have been suspended for calls made under the auspices of the Program. Because the Decree implementing the Law that created the program effected a transfer of ownership regulations, determining that the Ministry of Mines and Energy would an Operating Manual to the standards for the realization of the program, thus suspended the applicability of the rules that would conflict with the Operating Manual. With the end of the program and return the previous regulatory framework provides for an exclusion, so that legislative changes are proposed to transform what is government's programs in state policy and thus ensure that future generations do not suffer a electric system based on the exclusion of the poor residents of rural areas.
\end{abstract}

Keywords: Rural Electrification, Universal Access to Electricity, Luz para Todos Program. 


\section{SUMÁRIO}

1 - ANÁlise hiSTÓRICA DO PERÍODO QUE ANTECEDE O PROGRAMA LUZ PARA TODOS 005

1.1 - O Programa Luz no Campo 005

1.2 - Principais inovações 008

1.3 - A eletrificação rural no Brasil - as primeiras experiências, as companhias elétricas, os grandes programas das estatais e das cooperativas durante a Guerra Fria, a paralisação 009

1.4 - A interferência do BNDES 015

1.5 - A eletrificação rural vista como um serviço público essencial - a participação da Escola Politécnica 017

1.5.1 - A questão social 018

1.5.2 - A questão econômica 018

1.5.3 - A questão técnica 020

1.5.4 - A eletrificação rural sendo negada pelo Estado 023

1.5.5 - A eletrificação rural sendo negada pela concessionária 024

1.5.6 - A eletrificação rural sendo negada pela engenharia de distribuição___ 027

1.6 - A ruptura do dilema da eletrificação rural e o modelo BNDES/USP__ 028

1.7 - O papel das cooperativas de eletrificação rural 031

1.8 - A posição das concessionárias de distribuição do serviço público de energia elétrica

2 - DA ILEGALIDADE DA EXIGÊNCIA DE PARTICIPAÇÃO FINANCEIRA POR PARTE DO CONSUMIDOR DO SERVIÇO PÚBLICO DE ENERGIA ELÉTRICA

Nenhuma entrada de sumário foi encontrada.

3 - RESISTÊNCIAS À UNIVERSALIZAÇÃO DO ATENDIMENTO DE 2.002 044

4 - A ENERGIA ELÉTRICA COMO SERVIÇO PÚBLICO ESSENCIAL

4.1 - Energia elétrica e Direito do Consumidor 046 4.2 - Energia elétrica e Direito Ambiental 048

\section{5 - ANÁlISE DO MOMENTO QUE ANTECEDEU A LEI} UNIVERSALIZAÇÃO 049

6 - DA ELETRIFICAÇÃO RURAL DE 2000 À UNIVERSALIZAÇÃO DE 2002 055

7 - ESTABELECENDO NOVOS PARADIGMAS 058

7.1 - O pacto entre agentes econômicos, Estado e sociedade 060

7.2 A Lei 10.438, de 26 de abril de 2002 061

7.3 - A Resolução 223, de 29 de abril de 2003 063

8 - O PROGRAMA LUZ PARA TODOS 066

8.1 - A transferência da competência normativa 
10 - OS NÚMEROS DO PROGRAMA LUZ PARA TODOS NO ESTADO DE SÃO PAULO

10.1 - Alguns municípios e seus números interessantes

10.2 - Discrepância de números

10.3 - O que mostram as cidades e os números - critérios de exclusão 092

10.4 - Do crescimento vegetativo 096

11 - DE 31 DE DEZEMBRO DE 2010 A 10 DE NOVEMBRO DE 2003 098

12 - ASPECTOS QUE INDICAM UM DESEJO DE PERMANÊNCIA DAS CONDIÇÕES ESTABELECIDAS PELO PROGRAMA LUZ PARA TODOS_101

\section{3 - UNIVERSALIZAÇÃO DO ACESSO E USO DA ENERGIA ELÉTRICA_106}

13.1 - Direito ao acesso não é o mesmo que universalização do atendimento 106

3.2 - Da ilegalidade e inconstitucionalidade da participação financeira do consumidor de energia elétrica nos custos de conexão ao sistema 107

14 - PROBLEMAS, CONCLUSÕES E PROPOSTA DESTE TRABALHO 110 CONCLUSÃO 112 REFERÊNCIAS BIBLIOGRÁFICAS 114 


\section{INTRODUÇÃO}

Em uma sociedade justa, igualitária e democrática, o maior problema é como garantir efetividade aos direitos estabelecidos em Lei. Pode a Constituição determinar que a educação seja um direito de todos, mas, como tornar efetivo esse direito? E se for possível efetivar, criar salas de aula em abundância, contratar professores bem pagos e capacitados, seria justo suprimir essa efetividade já atingida?

Tema semelhante é o desta dissertação. Será tratado neste trabalho do direito de todos, em especial do morador pobre da área rural, acerca do acesso ao serviço público de distribuição de energia elétrica, sobre como está sendo possível efetivá-lo e porque não se deve abrir mão de avanços conquistados no campo dos direitos de cidadania. O objeto de estudo é o Programa Luz para Todos, programa do Governo Federal de universalização do acesso e uso da energia elétrica. O território delimitado é o Estado de São Paulo, e, embora haja menções em nível nacional, optouse em restringir o território para melhor desenvolver o tema.

A eletrificação rural no Brasil possui uma história longa de exclusão social. Durante vários anos o acesso à energia elétrica no meio rural foi resultado de políticas vinculadas a financiamentos internacionais, ou a iniciativas de governantes eventuais. Nesse longo período, estudiosos da eletrificação rural apontavam caminhos para que fosse possível atender, de forma integral, todos os moradores das áreas rurais do Brasil. A experiência demonstrou que todos os entraves existentes - custo das ligações, capacidade de pagamento dos moradores das áreas rurais etc., decorriam da inexistência de uma efetiva vontade política para se implementar as medidas necessárias, pois a eletrificação rural é uma questão política.

O marco inicial do trabalho foi o mês de dezembro de 1999, ocasião da publicação do Decreto Presidencial que criou o Programa Luz no Campo. Havia entraves de naturezas diversas a vencer, como a persistente resistência das concessionárias em atender às populações pobres do meio rural, o custo sob responsabilidade do consumidor, impagável, na maioria dos casos, para a gente pobre da roça. 
Para melhor entender o que se passou nesses últimos dez anos, em que milhões de brasileiros pobres do meio rural brasileiro saíram da escuridão, fazendo um salto fantástico de condições de vida do século XIX para o século XXI, foi necessário realizar uma análise histórica da eletrificação rural no Brasil.

Assim, este trabalho desenvolve uma análise do período no qual o investimento por parte da concessionária de energia elétrica era limitado a um valor irrisório, sendo o restante de responsabilidade do consumidor, o que dificultava e mesmo inviabilizava o pleno atendimento do serviço público de distribuição de energia elétrica no meio rural.

Apresenta estudos acerca de programas que antecederam o período da universalização do atendimento, mas que já possuíam esse conceito embutido em sua estrutura. Nesse ponto analisa-se, em particular, o papel do BNDES e da Escola Politécnica, naquele que passou a se chamar modelo BNDES-USP, aplicado no Estado de São Paulo, em meados dos anos 1990.

É desenvolvida também uma análise sobre a ilegalidade e inconstitucionalidade da exigência de participação financeira por parte do consumidor no acesso à rede de energia elétrica e de como, durante muito tempo, cobrou-se essa participação.

O estudo apresenta, ainda, a transição do conceito de eletrificação rural para o de universalização do atendimento e demonstra a caracterização do serviço de energia elétrica como serviço essencial, direito do consumidor e direito ambiental, que deve ser garantido às presentes e futuras gerações, a todos, no conceito do artigo 225, da Constituição Federal.

Foi na década de 1990, com a intervenção do BNDES, uma instituição governamental de fomento econômico e social, que se começou a quebrar alguns paradigmas. Começa a surgir a ideia de que o atendimento na área rural não deveria impor limites, mas atender a todos que solicitassem esse serviço. 
No final dessa década, foi lançado o Programa Luz no Campo, em nível nacional. Por meio desse programa começou-se a vislumbrar uma possibilidade de atendimento rural universal. Entretanto, havia alguns problemas a superar: a grande resistência das concessionárias, permissionárias e cooperativas de eletrificação rural, e o custo da participação financeira por parte do consumidor rural, pois esse Programa não era totalmente gratuito para o consumidor.

Foi somente em novembro de 2003 que houve a criação do Programa Luz para Todos. Seu maior atributo foi aproveitar o acúmulo de conhecimento existente e demonstrar vontade política para por em prática o que já se discutia entre os especialistas do tema.

A característica mais importante do Programa Luz para Todos foi estabelecer um arranjo financeiro que garante a total gratuidade para o consumidor rural, levando a energia elétrica até o interior de seu domicílio e, ao mesmo tempo, mantendo o equilíbrio econômico-financeiro do contrato de concessão. Para isso, lançou mão da utilização de recursos de dois fundos setoriais, da participação dos Estados e Municípios e da contrapartida dos agentes concessionários e permissionários.

Para a sua consecução, além do arranjo financeiro, houve uma transferência de titularidade normativa, ou seja, as normas para implementação do Programa passaram a ser responsabilidade do Ministério de Minas e Energia. Assim, durante a vigência do Programa, determinadas normas estabelecidas pela ANEEL tiveram sua eficácia suspensa. É o caso de alguns artigos da Resolução $n^{\circ} 456 / 00$, entre eles, o que determina o Ponto de Entrega.

O objetivo deste trabalho foi verificar se, com o término do Programa Luz para Todos - previsto para 31 de dezembro de 2010, haverá um retrocesso do ponto de vista do direito ao serviço público de energia.

O que se demonstra é que o Programa Luz para Todos, e suas regulamentações, estabeleceu as condições necessárias para se efetivar um direito essencial, de cidadania, a todos os moradores pobres do meio rural brasileiro. Fez isso durante sete anos, mostrou os caminhos e transformou, até o presente momento, a vida 
de mais de onze milhões de pessoas e que, diante disso, não se pode aceitar que esse direito, simplesmente, deixe de existir.

É pressuposto deste trabalho que o atendimento pode se dar tanto por extensão ou ampliação da rede elétrica, quanto por outras formas de geração de energia elétrica, como, por exemplo, o atendimento por sistemas solares fotovoltaicos. Os estudos visam garantir o atendimento de luz elétrica nas casas dos cidadãos brasileiros. Como se dará tal atendimento será uma decisão eminentemente técnica, em momento seguinte. Para isso, proporá alterações para adequar o sistema normativo do setor elétrico brasileiro aos mandamentos legais que o Programa Luz para Todos tornou efetivos.

O arcabouço metodológico estabelecido se baseou em pesquisa bibliográfica e pesquisa documental. Foi realizado levantamento de dados bibliográficos sobre o tema da eletrificação rural no Brasil antes do ano de 2000. A pesquisa documental foi utilizada para investigar e analisar os dados das fontes primárias, tais como as leis, resoluções, relatórios e outros. Os dados foram organizados segundo sua ocorrência cronológica e seus efeitos na realidade atual. A partir desse ponto, foram inferidas as conclusões deste trabalho. 


\section{1 - ANÁLISE HISTÓRICA DO PERÍODO QUE ANTECEDEU O PROGRAMA}

\section{LUZ PARA TODOS}

1.1 - O Programa Luz no Campo

No dia 3 de dezembro de 1999 o Diário Oficial da União trouxe publicado o Decreto Presidencial sem número, que instituiu o Programa Luz no Campo. Com sete artigos, esse decreto trouxe ao universo da eletrificação rural alterações significativas que merecem ser destacadas. O artigo $1^{\circ}$ instituiu o Programa Luz do Campo "com o objetivo de promover a melhoria das condições sócio-econômicas das áreas rurais do País."

Esse primeiro artigo já estabelecia um dado essencial: o de que o acesso à energia elétrica é fator de melhoria das condições socioeconômicas. Desse entendimento decorre que é necessário o acesso a esse serviço público, para que haja ganho nas condições socioeconômicas e, implicitamente, para que haja ganho de cidadania.

Já o artigo $2^{\circ}$ estabeleceu uma atuação articulada com outros programas e ações de governo, tais como Programa Nacional de Desenvolvimento Energético dos Estados e Municípios - PRODEEM, o Programa Nacional de Conservação de Energia Elétrica - PROCEL e o Programa Comunidade Solidária, deste modo estabeleceu-se uma transversalidade entre programas e ações governamentais.

$\mathrm{O}$ artigo $3^{\circ}$ tratou das fontes de recursos para a consecução dos objetivos do programa, sendo tais fontes a Reserva Global de Reversão - RGR e do Uso de Bem Publico - UBP.

$\mathrm{O}$ artigo $4^{\mathrm{o}}$ estabeleceu a possibilidade de prazos e condições diferenciadas para os estados das regiões Norte, Nordeste e Centro-Oeste, "em razão do seu baixo índice de eletrificação rural." $\mathrm{O}$ artigo $5^{\circ}$ definiu que a coordenação do Programa seria de responsabilidade do Ministério de Minas e Energia, por intermédio das Centrais Elétricas Brasileiras S.A. - Eletrobras. 
$\mathrm{O}$ artigo $6^{\circ}$, por sua vez, atribuiu ao Ministério de Minas e Energia a competência e a responsabilidade pela elaboração das normas para execução do Programa e o prazo para baixar tais normas, estipulado em trinta dias.

$\mathrm{O}$ artigo $7^{\circ}$, por fim, estabeleceu que a vigência do decreto se daria a partir da publicação do mesmo, portanto, a partir do dia 3 de dezembro de 1999.

Elencados os artigos do decreto cabe analisar os seus pontos mais significativos. $\mathrm{O}$ primeiro dado a se considerar não está expresso no texto, mas implícito. Trata-se de um programa de eletrificação rural de âmbito nacional. Ao utilizar no final, no artigo $1^{\circ}$, a expressão "áreas rurais do País", o decreto abrange a todos os moradores do meio rural do Brasil.

A eletrificação rural, até então, era primordialmente executada nas áreas de concessão ou de permissão das companhias elétricas ou cooperativas de eletrificação rural, trazendo em consequência, um caráter regional, ou ainda estadual, no caso de concessionárias estatais com abrangência na maior parte do território do estado.

O estabelecimento da fonte de recursos é outro dado de grande importância. Até então, as fontes de recursos utilizados em programas de eletrificação rural ou tinham origem em financiamentos internacionais, ou saiam dos orçamentos estaduais ou federal. A utilização de fundos setoriais originados do próprio setor elétrico transfere ao setor, ao conjunto de consumidores já conectados, a responsabilidade por viabilizar a inclusão de novos consumidores. Sendo dinheiro público, competia à União estabelecer a base legal para seu uso, e, com o passar do tempo e a evolução da base legal para permitir o bom uso dos recursos cuja fonte eram os consumidores de energia e cuja gestão competia à Eletrobras, o Ministério de Minas e Energia passou a arquitetar e impor instrumentos de caráter regulatório comandados pelo Poder Executivo, sobrestando a regulação da agência reguladora, que não é órgão de governo.

$\mathrm{Na}$ montagem desse novo arcabouço regulatório e na prática de seu exercício, que é inerente às operações do Programa Luz para Todos, está o roteiro da construção das bases que fundamentam esta dissertação. Essa arquitetura se inicia com a publicação do decreto que está sendo analisado, de dezembro de 1999. É importante a 
constatação de que ela tem vivido com continuidade nos seus dez anos de existência. Fortaleceu-se desde o início, consolidando-se com o lançamento do Programa Luz para Todos. Todavia, é uma estrutura dinâmica que se modifica premida pela práxis que tem o objetivo claro de promover a inclusão social por meio da chegada da energia elétrica a comunidades isoladas, esquecidas e, sempre, muito pobres. Ela se permite ir se aperfeiçoando, e certamente vai ser assim enquanto durar o Programa Luz para Todos.

Essa arquitetura regulatória permite, de fato, a inclusão social e a promoção da cidadania. Mas essa estrutura estará desmontada no dia em que esse programa terminar, o que é previsto para o final de 2010. Certamente que cuidados especiais estão sendo tomados para que a estrutura regulatória do setor elétrico brasileiro, regulamentada e garantida pela ANEEL, absorva itens que possibilitem a continuidade do caráter de inclusão social. O que motiva o autor é que, mesmo assim, uma parte da população alvo ficará de fora do acesso à energia elétrica. Este trabalho de pesquisa pretende analisar tais aspectos - que entende serem barreiras efetivas à inclusão social - e propor alternativas para a superação dessas barreiras.

São dez anos de movimento firme, coerente e bem orientado. Então, pode-se afirmar que os fenômenos que determinam a trajetória atual da eletrificação rural no Brasil são recentes.

Naquele último mês do ano de 1999, o Programa Luz no Campo foi lançado, na cerimônia de encerramento do XVI Congresso Latino-Americano de Eletrificação Rural, no Município de Recife-PE.

1.2 - Principais inovações

Foi nesse momento que:

1. O Governo Federal assumiu que uma quantidade significativa de cidadãos brasileiros vivia sem energia elétrica nas áreas rurais do país, e que isso dizia respeito às responsabilidades de Estado.

2. A Eletrobras recebeu atribuições de agência federal encarregada 
de gerir um programa nacional de eletrificação rural, impondo regras para a consecução dos objetivos e fiscalizando o bom uso do dinheiro público.

3. Todos os estados da Federação foram envolvidos, tanto os que demandavam eletrificação, quanto aqueles que proclamavam que determinadas regiões não precisavam de eletrificação e que tal programa não seria de interesse local.

4. Todas as empresas distribuidoras foram envolvidas.

5. Foram disponibilizados recursos setoriais, derivados do pagamento das contas de consumo de energia dos consumidores brasileiros, para financiamento do programa.

6. A eletrificação rural seria executada sem necessidade de aporte de recursos externos ou dos orçamentos federal, estadual ou municipal.

7. O baixo custo da ligação foi imposto como uma exigência efetiva.

8. A eletrificação rural foi declarada como de interesse eminentemente social, voltada para a melhoria da qualidade de vida, prioritariamente.

9. Foram feitas exigências no sentido de se dar preferência a circuitos monofásicos.

10. Passou-se a se empregar a expressão "universalização do atendimento" e alguns estados teriam como meta alcançar essa "universalização".

A maioria desses itens constituía total novidade. Alguns já eram aplicados em alguns estados, ou em algumas circunstâncias. Todavia, em âmbito nacional, esses fenômenos ainda eram todos raros e, a partir daquela data inaugural, constituem-se como linhas que conduzem o desenvolvimento da eletrificação rural no Brasil atual.

Pode-se dizer que, a partir do momento em que tais conceitos e diretivas 
tomaram lugar no processo de levar energia elétrica a todo o meio rural brasileiro, a própria expressão "eletrificação rural” passou a ter uma conotação mais histórica, como referência para as experiências que levaram às teorias e propostas de "universalização do acesso", ocupando esta segunda o lugar da primeira, ou seja, a evolução teórica e prática da eletrificação rural levou à superação de antigos paradigmas e ao estabelecimento de novos paradigmas, que antes eram propostas ou anseios dos pesquisadores, acarretando na superação do conceito de eletrificação rural, colocando em seu lugar o de universalização do acesso e uso da energia elétrica.

Há novos temas a tratar em vista dos novos paradigmas que se colocam a partir do termo "universalização" (PELEGRINI, 2003). Por tais motivos, esta pesquisa, com o objetivo de, a partir desse mesmo cenário contemporâneo, prospectar o futuro da eletrificação rural a médio e a longo prazo, amarra seu ponto de partida nesse mesmo marco da virada do século.

No entanto, o pesquisador que pretender compreender a dinâmica da eletrificação rural não pode se restringir ao exame de um quadro, como se fosse a fotografia da situação inicial. Tampouco pode imaginar que sua dinâmica é restrita à sua experiência no Brasil. (RIBEIRO, 1993)

1.3 - A eletrificação rural no Brasil - as primeiras experiências, as companhias elétricas, os grandes programas das estatais e das cooperativas durante a Guerra Fria, a paralisação

O meio rural brasileiro viu chegar a luz elétrica na década de 1920, em comunidades étnicas no interior dos estados do sul do país. A primeira cooperativa foi implantada em 1941, na localidade de Quatro Irmãos, no Rio Grande do Sul. (TENDRIH, 1990).

No Estado de São Paulo, dois poderosos grupos estrangeiros se estabeleceram já nos primórdios da indústria elétrica, assumindo o controle de duas diferentes empresas de energia elétrica (SODRÉ, 1997). Na capital e seu entorno havia a Light anglo-canadense, desde o final do século XIX, quando vendeu títulos para financiar a substituição de transporte urbano por tração animal sobre trilhos pelo 
moderno transporte elétrico também sobre trilhos. $\mathrm{Na}$ Inglaterra, esses títulos eram chamados de "bonds" e foram vendidos com a promessa de retornar altos rendimentos. Não houve esse esperado retorno e quem os comprou teve só prejuízo. Desde então, dizer que alguém comprou um bonde significa comprar algo que não dá lucro. E, desde então, o transporte que em Lisboa se chama "electrico", no Brasil se chama bonde. (RIBEIRO, 2010)

Logo depois, em Campinas instalaram-se os americanos da Electric Bond and Share, no comando da Companhia Paulista de Energia Elétrica - mais tarde CPFL, que sempre teve o melhor mercado rural de energia elétrica do Brasil. Eram duas empresas com fortes culturas próprias e com concepções de engenharia diferentes, importadas dos países de onde vieram os capitais. (BRANCO, 1975) Havia, ainda, pequenas empresas isoladas pelo interior, algumas delas com capitais familiares, distribuindo energia nas regiões onde tinham implantado pequenas usinas hidrelétricas.

O Brasil passou por um grande processo de modernização na metade do século XX, no período do pós-guerra. A economia avançou. Grandes empresas estruturantes foram criadas.

Surgiu a CHESF, em meados dos anos 1940, inaugurando as três primeiras unidades de Paulo Afonso em 1955. O espectro da Guerra Fria foi se assomando e os países subdesenvolvidos da área de influência dos Estados Unidos foram contemplados com grandes investimentos das agências multilaterais, principalmente o Banco Mundial e o Banco Interamericano de Desenvolvimento - BID, além da United States Agency for International Development - USAID. Nos anos 1.950 foram criados o Banco Nacional de Desenvolvimento Econômico, então BNDE, a PETROBRAS, a CEMIG, a CEEE, no Rio Grande do Sul, e a Eletrobras, entre outras grandes empresas. (TENDRIH, 1990)

Furnas Centrais Elétricas foi instituída em 1957, pelo presidente Juscelino Kubitschek. A antecipação das obras das linhas de transmissão em 345 kV, de Furnas a Poços de Caldas, e daí para Guarulhos e Mogi das Cruzes, livrou a capital bandeirante do maior racionamento de sua história. A represa Billings secou, virou um ribeirão no meio de um lamaçal com barcos abandonados no barro seco, as vitrines 
foram apagadas, a iluminação pública, a situação foi piorando até que, de repente, surgiu a luz de Furnas, iluminando os paulistas antes do cronograma, mas na hora certa. (RIBEIRO, 2010)

$\mathrm{Na}$ sequência, as empresas de energia dos estados foram sendo transformadas em empresas estatais, com os respectivos tesouros estaduais instituídos como os principais acionistas.

As concessionárias foram deixando de ser empresas de capital estrangeiro para se tornarem instrumentos conduzidos pelos governantes estaduais e seus grupos de interesse. (BRANCO, 1975)

Sessenta anos atrás, em uma época de petróleo barato, o estado de São Paulo tinha um governador que era emérito professor de Hidráulica. Tinha autoridade política e técnica para propor e insistir no debate da geração hídrica, a qual trazia atrelada a ideia da expansão da eletrificação rural. Contrariando opiniões importantes do meio empresarial (BRANCO, 1975), foi realizado, em 1957, o Seminário Internacional de Eletrificação Rural, patrocinado pela Organização dos Estados Americanos, e surgiu, em São Paulo, o Serviço Especial de Eletrificação Rural. (TENDRIH, 1990). Muitas das pequenas e médias empresas do interior paulista foram sendo agrupadas à CESP, então Centrais Elétricas de São Paulo, empresa montada para projetar e construir as Usinas de Urubupungá, depois denominadas Usina de Jupiá e Usina de Ilha Solteira. O velho professor Garcez era o líder desse empreendimento. O complexo de Urubupungá era apresentado como o maior gerador elétrico do mundo. $\mathrm{O}$ sistema de transmissão tinha linhas de $440 \mathrm{kV}$ em circuito duplo, com 600 quilômetros de comprimento. Era de uma sofisticação ainda desconhecida. E a CESP ficou com os sistemas de distribuição existentes nos entornos das usinas que incorporou, ficou com a concessão da distribuição ao redor de suas novas geradoras, e com as falhas de fornecimento pelo interior, regiões cujos mercados não eram de interesse dos capitalistas da Light e da CPFL. Sendo empresa estatal e era natural que o estado de São Paulo a usasse para completar a rede pelo interior. Muitas cidades que não tinham luz elétrica foram sendo eletrificadas. A última cidade que saiu do escuro foi Barra do Turvo. (RIBEIRO, 2009)

Em resumo, a distribuição de energia do estado de São Paulo ficou com 
três grandes concessionárias estatais e várias pequenas concessionárias privadas de alcance regional. Entretanto, as três estatais eram completamente diferentes em suas culturas técnicas. A Light, empresa de origem anglo-canadense de mercado fortemente concentrado na região da capital, tendo ainda os mercados industrializados da região de Sorocaba, de Santos e de parte de vale do Vale do Paraíba, onde estão as maiores cidades e suas fábricas. Tinha também a concessão de parte do Litoral Norte, com mercado fraco e sazonal. Outra empresa de origem americana em Campinas e no interior mais rico, a CPFL, com mercado de grandes fazenda e empresas rurais, e muitas fábricas. E uma terceira empresa cujo mercado era pobre e carente tanto de infraestrutura de subtransmissão, como de expansão da distribuição. Havia ainda, em São Paulo, um grande número de cooperativas de eletrificação rural. Elas tinham apoio do governo estadual por meio do Departamento de Águas e Energia Elétrica - DAEE e se consolidaram como empresas fortes, de caráter cooperativo. Tal apoio incluía orientação técnica para gestão e ampliação de seus sistemas de potência. (JUCÁ, 2007) Suas diretorias eram formadas por lideranças políticas conservadoras, fazendeiros ligados à base governista advindas, quase sempre, de uma oligarquia de antigos proprietários rurais. As relações partidárias das cooperativas com os governos municipais, estadual e federal estavam sempre permeando as atividades dessas empresas relativas a seus objetivos de distribuir energia elétrica. (PELEGRINI, 2003)

Em vários países subdesenvolvidos foram feitos investimentos do Banco Mundial, principalmente, e de outras agências multilaterais em programas nacionais de eletrificação rural. Eram investimentos dirigidos à concepção de desenvolvimento imposta pelas potências do mundo ocidental, sempre privilegiando a capacidade de geração de renda para permitir o retorno econômico. Essa mesma concepção desenvolvimentista do Banco Mundial se manifestava nas operações industriais, de infraestrutura, e de investimentos nos grandes empreendimentos agrícolas. A eletrificação rural era mais uma operação de desenvolvimento com a imposição dos mesmos objetivos, envolvendo o setor agrícola e o setor de infraestrutura de energia. Os objetivos sociais eram meramente secundários. Há muita bibliografia de consultores americanos e europeus fruto das avaliações desses programas. O tema mais comum era a pergunta se a eletrificação rural era capaz de produzir riquezas, ou se era a riqueza que produzia a eletrificação rural? Como era sempre difícil encontrar retorno econômico apreciável nos investimentos de eletrificação rural, também havia a discussão se não 
seria mais importante um país priorizar outros investimentos, como saúde, educação, ou em transporte e deixar a eletricidade para uma fase seguinte em seu desenvolvimento. Houve até uma avaliação, na América Central, sobre como a eletrificação rural se relacionava com as insurgências. Seria um inibidor de insurgências? (RIBEIRO, 1993)

Os organismos internacionais forçaram a criação de cooperativas, tal como era nos Estados Unidos. Esse modelo foi fortemente adotado em Minas Gerais, onde foi criada a Eletrificação Rural de Minas Gerais - ERMIG. Como nos Estados Unidos, a distribuição primária em Minas Gerais era monofásica com dois fios, fase e neutro aterrado. (CORREIA, 1992)

As agências internacionais aumentaram sua influência a partir de 1964. Assim foi estabelecida a estrutura cooperativista como forma de disseminar a eletrificação rural. Surgiram privilégios, foram concedidos subsídios e, em vários estados, as cooperativas implementaram programas de eletrificação rural. Entre eles, destacaram-se os estados de Pernambuco, Minas Gerais, São Paulo, Paraná, Santa Catarina e Rio Grande do Sul. Esse modelo não perdurou, sendo que, em muitos estados as cooperativas tiveram dificuldades financeiras e, uma a uma, foram sendo absorvidas pelas concessionárias, a partir do final da década de 1.960. (TENDRIH, 1.990)

Os decretos $n^{\circ} 62.655$ e 62.724, ambos do ano de 1968, com diferença de duas semanas entre si, um do dia 3 de maio outro do dia 17 do mesmo mês, tinham por objetivo regulamentar a execução de serviços de eletrificação rural e estabelecer normas para tarifação da distribuição de energia elétrica, respectivamente.

O decreto $n^{\circ} 62.655$ definia detalhadamente o que seria eletrificação rural e os conceitos e definições ali adotados foram incorporados pelo decreto seguinte. Essas definições afastavam as cooperativas de eletrificação rural de qualquer possibilidade de atendimento a núcleos urbanos e suburbanos, fazendo valer uma reserva de mercado para as concessionárias. (PELEGRINI, 2003)

No Brasil, o capital externo para programas de infraestrutura ficou farto, como ponto de apoio para o regime militar se alavancar. Com capital financiado por agências multinacionais surgiram grandes programas de eletrificação. (TENDRIH, 
1990) Em 1970, foi criado o Grupo Executivo de Eletrificação Rural - GEER, para gerir o I Programa Nacional de Eletrificação Rural - I PNER, que atendeu a 32.500 consumidores, até 1977. Sucedeu-o o II PNER, atendendo 73.000 consumidores. (RIBEIRO, 1993)

Entre 1971 e 1980, a Eletrobras atendeu a 120.000 famílias, em programa que desenvolveu em dezesseis estados, gerido pelo Departamento de Eletrificação Rural - DEER. O Banco Mundial apoiou esse programa com financiamento para obras e para pesquisa, mantendo consultor no Brasil, durante certo tempo. Surgiram os primeiros estudos de eletrificação rural simplificada, com a publicação de dez volumes intitulados "Relatórios de Eletrificação Rural - RER Eletrobras". Um dos relatórios é o primeiro manual brasileiro de Sistema Monofilar com Retorno por Terra e ficou muito conhecido. (RIBEIRO,1993). Havia o DEER movimentando recursos do Ministério de Minas e Energia e havia o GEER, gerido pelo Ministério da Agricultura, aplicando recursos do Banco Interamericano de Desenvolvimento, por meio do II PNER. Um voltado para as concessionárias, outro para as cooperativas. (CORREIA, 1992)

A eletrificação rural do Brasil tornou-se uma grande confusão institucional. Recursos internacionais abundantes davam poder ao Ministério da Agricultura e força às cooperativas. Ficou clara a existência de conflito com as concessionárias. Entre essas, destacavam-se grandes programas de âmbito estadual, em Minas Gerais, com a CEMIG e no Paraná, com a COPEL. A primeira usando circuitos primários com dois condutores e a segunda, usando sistema monofásico com retorno por terra, sistema MRT, com apenas um condutor, sendo que a corrente de retorno circula pela terra. Ambos os programas eram financiados com recursos de empréstimo para eletrificação rural que o Banco Mundial e o BID concederam à Eletrobras em 1983, os quais foram repassados às duas concessionárias estaduais. (SANTOS, 1996)

A eletrificação rural tornou-se uma grande confusão e, então, parou. Não houve mais programas nacionais ou estaduais, a Eletrobras deixou de se interessar pelo problema. (RIBEIRO, 1993) Na década de 1980, o dinheiro externo deixou de existir. Nessa década, o atendimento médio anual das demandas por energia elétrica na área rural foi de menos de 2\%. O Brasil chegou a 1990 com taxa de atendimento de apenas 27\%. (RIBEIRO; SANTOS, 1994) Dados do Governo Federal demonstram que três 
quartos dos cinco milhões de propriedades rurais brasileiros estavam no escuro. (DENACOOP, 1991)

O setor elétrico brasileiro tornou-se mais corporativo que nunca. As grandes empresas estaduais eram verticalizadas, isto é, reuniam atividades de geração, transmissão e distribuição, o que, aliás, é proibido no quadro atual. O atendimento de consumidores rurais passou a ser relegado em praticamente todas as distribuidoras do país.

\section{4 - A interferência do BNDES}

O governo militar criou um novo tributo, o FINSOCIAL. Parte dele serviria para financiar projetos de interesse social e foi determinado que o então BNDE ficasse encarregado de administrar os investimentos, podendo conceder subvenções para projetos de caráter de desenvolvimento social. Para isso, o banco ganhou uma letra a mais no nome, a letra "S", passando a ser, a partir do ano de 1982, o Banco Nacional de Desenvolvimento Econômico e Social - BNDES. (TENDRIH, 1990)

Já no governo Sarney (1986-1990), conhecido como "Nova República", o BNDES resolveu financiar um projeto inovador de eletrificação rural simplificada que utilizava o sistema MRT e outros itens, como transformador monobucha de pequeno porte, poste de madeira, condutores de aço zincado, e construção pelo sistema de mutirão, no Município gaúcho de Palmares do Sul. (RIBEIRO, 1993) Tais itens de simplificação passaram a ganhar destaque na discussão da eletrificação rural.

O Projeto Palmares do Sul foi um sucesso, na visão do BNDES (SANTOS, 1996). Tinha sido conduzido por um engenheiro agrônomo e tal fato permitiu que a concessionária local não o levasse a sério, tal como relata o engenheiro Fábio Rosa, no livro "Como mudar o mundo - empreendedores sociais e o poder de novas idéias", do jornalista David Borstein, 2005, o qual se tornou um "best seller" internacional.

Relata ainda o engenheiro que o BNDES procurou a Escola Politécnica da Universidade de São Paulo, para dar apoio técnico ao projeto e fazer um julgamento 
de valor sobre o fato de o pobre rural nunca ser incluído efetivamente no público dos programas de eletrificação rural (BORSTEIN, 2005). Paralelamente, a Escola Politécnica passou a atuar como consultora do BNDES no planejamento de um programa inovador de eletrificação de propriedades rurais de baixa renda, conduzido pelo Banco de Desenvolvimento do Rio Grande do Sul - Badesul - que repassava recursos do Finsocial e do Fundo de Amparo ao Trabalhador - FAT - diretamente aos interessados. O Badesul atuava como uma agência de desenvolvimento coordenando o programa, ao invés da concessionária. Havia uma filosofia de projeto que exigia circuitos simplificados, pelo sistema MRT. A Politécnica avaliava cada projeto, atestando se estava de acordo com os princípios filosóficos da política do BNDES. (RIBEIRO; SANTOS, 1994)

\section{5 - A participação da Escola Politécnica}

Estimulada pelo BNDES, a Escola Politécnica criou um grupo de pesquisa multidisciplinar que se intitulou "Energia e Desenvolvimento Rural" tornandose essa uma de suas linhas de pesquisa. (SANTOS, 1994)

Este trabalho formula a hipótese de que em futuro próximo, para parte do público rural que ainda não tiver sido atendido pelo serviço público de distribuição de energia elétrica a situação será muito semelhante à situação predominante no Brasil há vinte anos.

Por considerar semelhantes os cenários, isto é, que os condicionantes de vinte anos atrás estarão presentes no cenário futuro, onde ficarão escondidos na escuridão os cidadãos que moram longe da estrada, os colonos que moram em propriedades do fazendeiro, ou ainda, as futuras famílias que forem se constituindo para viver em situações semelhantes - longe da divisa da propriedade, ou em uma propriedade já atendida por eletricidade, esta pesquisa analisa alguns dos resultados então publicados pela Escola Politécnica.

A eletrificação rural foi tomada como uma questão política. Sua discussão passa por aspectos sociais, econômicos e técnicos. Nessas três instâncias destaca-se o caráter político das decisões. 
Nessas três instâncias são encontrados velhos entraves que por conservadorismo e tradição podem ter sobrevivido em uma espécie de "hibernação". Muitos elementos encontrados até a década de 1990 na eletrificação rural das concessionárias poderão despertar de uma hibernação em 2011, logo depois de terminada a vigência da regulação do Programa Luz para Todos, em consequência ao seu encerramento previsto para o final de 2010. Uma vez comprovada essa hipótese, o autor terá facilidade para afirmar que parcelas de famílias rurais acima identificadas não serão atingida pela universalização do atendimento, prevista hoje em lei.

SANTOS, (1996), com sua visão de funcionário da Diretoria de Desenvolvimento Rural do BNDES, declara que “com o apoio dado pela Escola Politécnica quanto à viabilidade dos circuitos simplificados, o BNDES encontrou o suporte técnico que necessitava para aprofundar a questão." (SANTOS, 1996 p. 26).

1.5.1 - A questão social

A eletrificação rural foi caracterizada como um processo social. $\mathrm{Na}$ visão que se tinha, nessa época de 1990:

\footnotetext{
"Quando se percebe a idéia da energia elétrica como um bem público, a eletrificação fica caracterizada como um processo social. É um serviço público, objeto de um poder concedente, objeto de uma decisão do estado em concedê-la. O estado outorga esse poder à concessionária. E é justamente o substrato político da empresa concessionária que faz ou não florescer o processo de eletrificação." (RIBEIRO, 1993 p.47)
}

Como processo social, constatou-se que "fica nítido o chamamento da eletrificação como meio de aliviar pressões sociais no campo” como afirma RIBEIRO, (1993). Ou ainda que "a eletrificação rural é um potente vetor de descompressão do campo social e aplainamento das desigualdades entre as condições de vida da cidade e do campo" (RIBEIRO, 1993 p. 50).

Um dos objetivos das equipes de investigação era encontrar meios de aprimorar a formação dos engenheiros, em particular dos engenheiros eletricistas. No entanto, a pesquisa mostrou que essas características sociais não chegavam a 
impressionar favoravelmente as equipes técnicas que operam a eletrificação rural.

As pesquisas concluíram que era um processo social cujos frutos tinham um apelo político muito forte. Um aspecto comum era que, em muitas concessionárias estatais, a ideia de eletrificação rural era associada à ideia de favorecimento de políticos de prestígio com o governador do estado. (PAZZINI, 1998)

\subsection{2 - A questão econômica}

Do ponto de vista econômico, a pesquisa da Escola Politécnica concluiu, ressaltando se tratar de investigações antigas, que oferecer energia a consumidores rurais esparsos, distantes das fontes e sem capital só era considerado possível pelas empresas, se fosse com subsídio do Estado. (PELEGRINI, 1998)

Alguns setores da economia receberam doses sólidas de subsídio, por sucessivos governos. Mesmo na área de energia, a lista histórica de subsídios pagos pela sociedade é robusta. Os custos da ligação de energia nas moradias pobres crescem ao longo do tempo, pois as obras mais baratas acabam sendo feitas primeiramente. Vão ficando justamente por fazer as mais caras. É da natureza da engenharia fazer dessa maneira.

As distribuidoras se acostumaram a não fazer tais investimentos, a não ser com alguma forma de subsídio, ou financiamento privilegiado.

\footnotetext{
"A lição mais importante é que a grande barreira a ser vencida é o custo da instalação. Um povo empobrecido não tem como pagá-lo. Porém, um governo que realmente esteja empenhado em inserir em sua política de desenvolvimento econômico os segmentos mais carentes da nação deve e pode faze-lo" (RIBEIRO, 1993 p.61)
}

A questão mais importante era e ainda é o custo, todavia, ficava claro que o fato de vencer essa barreira não significava que as obras estivessem garantidas. Outras barreiras existiam, e já se viu que a falta de interesse dos engenheiros eletricistas era e é um entrave permanente.

Ainda do ponto de vista econômico, há um preconceito que influencia 
negativamente as empresas perante a eletrificação rural: as concessionárias, normalmente, não se entusiasmam por trabalhos cujos resultados só beneficiam gente pobre, sem representatividade dentro da empresa. (SANTOS, 1994)

O BNDES constatou, há vinte anos, rejeição a ofertas de financiamento para programas de eletrificação rural. Em 1990, o banco ofereceu linhas de crédito a concessionárias públicas de São Paulo e também a cooperativas e não houve uma que aceitasse. (RIBEIRO; SANTOS, 1994)

Os citados autores ressaltam que esse oferecimento de abertura de linhas de crédito aconteceu durante uma época atípica da história do Brasil. Era o início do governo Collor (1990 - 1992) e o açodamento do neoliberalismo impunha o impedimento de concessão de créditos públicos ao mercado. O BNDES justificava a oferta por atender a outro chamado neoliberal, que era a modernização da produção. Teria convencido os teóricos da equipe de governo que uma agricultura sem energia elétrica não poderia disputar com eficácia sua inserção no mercado competitivo global. Todavia, nem a ideia de colaborar com o governo na inserção competitiva de suas áreas de concessão e permissão fazia movimentar as concessionárias e cooperativas em direção à eletrificação rural. E não era por causa dos custos, já que haveria subsídios. (RIBEIRO; SANTOS, 1994)

\subsection{3 - A questão técnica}

É oportuno examinar alguns aspectos técnicos investigados nessa pesquisa de vinte anos atrás, porque se presume que se correlacionem com questões atuais que estão envolvidas com os objetivos aqui propostos.

De acordo com RIBEIRO, (1993), as concessionárias de distribuição de energia tiraram de si uma fotografia reveladora da situação da eletrificação rural da época. Em 1989, o antigo Comitê de Distribuição - CODI - reuniu as empresas que lhe eram convenentes, as do Centro-Sul do Brasil, mais a Coelba, da Bahia, para responder a um questionário. Em 1990, o CCON, que congregava as concessionárias do NorteNordeste repetiu as mesmas perguntas às suas convenentes. Essas associações de distribuidoras em 1995 foram substituídas pela Abradee, Associação Brasileira de 
Distribuidores de Energia Elétrica, que é uma sociedade civil de direito privado que reúne e representa 48 concessionárias de distribuição de energia.

CORREIA, (1992) apresentou os resultados de respostas a 118 perguntas sobre eletrificação rural, formuladas pelas duas associações de classe, agrupando as respostas dadas, por 24 empresas, de vinte estados diferentes. O objetivo era verificar como as concessionárias do Brasil se posicionavam perante os itens de simplificação da eletrificação rural, tais como o uso do sistema MRT, poste de madeira, trabalho por mutirão, aterramento, potência nominal de transformadores, e outros. Outros pontos de interesse também foram questionados.

As mesmas perguntas eram divididas em quatro grandes tópicos:

1. Organização, planejamento.

2. Projeto, construção e gerenciamento.

3. Operação e manutenção.

4. Fornecimento de energia, avaliação, segurança e imposto ambiental.

Ficou constatado que todos os procedimentos técnicos que eram citados como itens de simplificação dos sistemas e, consequentemente, de redução dos custos de instalação da eletrificação rural, eram utilizados com sucesso por uma ou mais empresas. Logo, poderiam ser adotados, com toda a segurança e confiabilidade que se conhecia das outras experiências, pelas outras concessionárias. Mas, elas se negavam a adotar, alegando a obediência às normas peculiares de cada uma. (CORREIA, 1992).

A diversidade de procedimentos era muito grande. Certamente que isso implicava em uma constatação importante: "existe uma grande relação entre os custos modulares para fins idênticos, acarretando variação média da ordem de 1 para 4" (CORREIA, 1992 p 85)

Durante as pesquisas para esta dissertação verificou-se que essa atitude persiste na engenharia no cenário atual, com a consequência de dificultar e mesmo impedir que soluções inovadoras introduzidas por algumas empresas, mesmo que avaliadas como possuidoras de viabilidade comprovada, sejam adotadas por outras. A 
persistirem tais níveis de variação de procedimentos e custos, isso significará a existência de barreiras que tendem a dificultar o atendimento nas situações que neste trabalho serão abordadas adiante.

Outro ponto de interesse técnico foi considerado relevante. Em publicações mais recentes do mesmo grupo de pesquisa, foram relatados entraves intencionalmente construídos por engenheiros de distribuição. Segundo JUCÁ, (1998), o Governo do Estado de São Paulo estava implementando um projeto de eletrificação rural em 1.996, intitulado Programa Luz da Terra, e o processo dependia de determinados pareceres de gerentes das concessionárias públicas. Porém, tais empresas estavam prestes a sofrer processos de privatização. Havia engenheiros que boicotavam o processo imaginando que o futuro dono da empresa iria valorizar um funcionário que tivesse tido iniciativas para impedir o envolvimento da empresa com o compromisso de eletrificação rural no momento que antecedeu sua venda. (JUCÁ, 1998)

O tema da dificuldade de engenheiros eletricistas aceitarem a eletrificação rural e tomar atitude positiva perante esse trabalho não é peculiaridade do Brasil. Outros autores tratam do tema.

Gerald Foley, considerado um dos autores mais importantes e consultor do Banco Mundial, assim falava do entusiasmo que pode provocar a eletrificação rural nos eletricistas. A opinião deste autor é que essa fala valha para o tempo de hoje:

\footnotetext{
"A eletrificação rural também pode trazer problemas de motivação nas equipes das concessionárias, particularmente entre os engenheiros e técnicos de distribuição. Do ponto de vista dos engenheiros eletricistas, particularmente entre os mais jovens e entusiasmados, a eletrificação rural oferece muito pouco de interesse profissional. O projeto de sistemas de distribuição rurais de baixa tensão não é um trabalho de prestígio ou desafio técnico, como o são os trabalhos em subestações ou em redes de alta tensão. Também significa estar trabalhando no campo, ao invés de nas cidades. Para muitos jovens engenheiros, ser colocado para trabalhar na eletrificação rural, se não é exatamente desmotivador, significa estar sendo removido da cadeia de promoções.” (FOLEY, 1992 p.72)
}

Foi constatado que não havia uma política de Estado para a eletrificação rural e que a maioria das famílias ainda sem luz elétrica só teria possibilidade de ser incluída ao atendimento de eletricidade por meio de um programa que adotasse soluções 
de baixo custo, desenhado explicitamente para atender o pobre rural. (SANTOS, 1996). Não havendo tal interesse de Estado, havia o repasse das decisões para a concessionária, e, em última análise, para as equipes de engenharia dessas empresas. Hoje, há uma política de governo explicitamente planejada para a inclusão do pobre rural no público alvo do sistema de energia. Esta dissertação identifica que uma classe de cidadãos ficará fora do alvo desse atendimento social, em futuro próximo. Ficará ao desabrigo da Lei de Universalização.

Havia, pois, um problema da eletrificação rural e muitos autores estudavam esse problema. Em particular, TENDRIH, (1990), analisava o problema do ponto de vista da estrutura do modelo econômico vigente e identificava uma incompatibilidade entre o modelo de desenvolvimento brasileiro e o atendimento de pequenos produtores rurais. FOLEY, (1992), textualmente identificava um dilema na gestão das concessionárias, entre atender os consumidores urbanos, os quais eram concentrados, de maior capacidade de consumo, menor gasto com manutenção e muito mais influentes quando reclamavam a prioridade das atenções da empresa para as questões referentes a seu atendimento, e fazer eletrificação rural. E LESSA, (1988), identificava um dilema da engenharia de distribuição, entre fornecer um serviço público de excelência ou trabalhar por um serviço público extensivo a todos os interessados em eletrificação rural. (RIBEIRO; SANTOS, 1992)

A pesquisa da Politécnica formulou o julgamento de que havia uma rede de interesses que impediam o atendimento rural e o expressou na forma da existência de um grande dilema da eletrificação rural: fazer eletrificação rural, ou não fazer? (RIBEIRO, 1993).

Esse dilema se manifestava em três instâncias e em todas elas a saída encontrada era sempre a mesma: negar que fosse preciso fazer eletrificação rural, negar que houvesse um problema de eletrificação rural.

1.5.4 - A eletrificação rural sendo negada pelo Estado

Essa questão dizia respeito a uma estratégia de desenvolvimento fundamentada no modelo econômico. Por um lado, a direção de um eixo do modelo 
desenvolvimentista influenciado por organismos internacionais, sempre voltado para o crescimento e a produção de bens que tivessem garantido o retorno econômico; e, por outro lado, o fato de não ser politicamente adequado assumir que não interessava a inclusão de famílias pobres no processo social da eletrificação rural, e tampouco ser aceitável manter parte do setor agrícola sem energia e simultaneamente proclamar que se buscava a modernidade e a competitividade para esse setor. Havia um grande dilema de planejamento, pois no Estado era consensual que eletrificação rural não fomentava crescimento nem trazia retorno econômico.

O Estado fugia desse dilema pela descaracterização do processo. Omitiase, tanto em relação ao seu dever constitucional de responsável pelo serviço público essencial concedido, quanto a seu dever de promover a redução da pobreza da população do campo. Negando sua participação nesse processo por meio da própria omissão, a situação ficava como se a responsabilidade social do Estado fosse transferida juntamente com a outorga de poderes à concessionária. Assim, o dilema da eletrificação rural deixava de existir para o Estado, e o problema era transferido para a concessionária, juntamente com a possibilidade de ela exercer, de fato, uma parte do poder concedente, pois era ela que tomava as decisões. (RIBEIRO, 1997)

\subsection{5 - A eletrificação rural sendo negada pela concessionária}

Com a ausência do Estado, o poder efetivo ficava, em parte considerável, com a concessionária, dando a ela força de executora do poder concedente junto ao público da área rural. A política de Estado com relação ao atendimento desse público era aquela estipulada pelo setor de distribuição de cada empresa.

\footnotetext{
"O caráter político da energia elétrica, de ser um serviço público que a concessionária efetivamente controla, tem um significado relevante no setor de distribuição: é lá que se atende o público, é a distribuição que detém o poder de decidir que rota vai tomar a linha que fornece energia" (RIBEIRO - 1993 p.87)
}

Era difícil a conciliação da eletrificação rural com os objetivos gerais da empresa. A expansão das linhas rurais causa conflito de interesses. As linhas são mais longas, a manutenção mais difícil e cara, o que é agravado pelas distâncias maiores e pelas condições das estradas rurais, o mercado é rarefeito e pobre, sem perspectivas de 
grandes consumos e de rentabilidade que possa ser considerada adequada perante os objetivos mercantis da distribuidora.

As concessionárias negavam a existência do problema com $\mathrm{o}$ atendimento rural simplesmente relegando-o à escala de prioridades naturais do setor de distribuição. Primeiro, precisavam ser atendidos os problemas de quem já tinha energia, principalmente o consumidor urbano e industrial. Por conta dos compromissos com essa outra clientela, de maior representatividade, poder aquisitivo e poder de informação, a eletrificação rural passava a ser um problema esquecido, aguardando-se um momento oportuno para se tratar dela. Seria quando ela chegasse ao topo da escala de prioridades. A certeza de que esse momento nunca haveria de chegar é uma manifestação clara de que, conscientemente, a concessionária negava a existência de tal problema. (RIBEIRO; SANTOS, 1994)

Outra forma de negar era a própria negação da importância que a energia poderia ter para esses novos consumidores ainda por atender. RIBEIRO, 1993, relata que ouvia nas concessionárias os seguintes comentários para justificar a decisão de não atender: “...eles não têm o que fazer com a energia, não agregam valor...”; “...só querem luz para iluminar a casa...”; “...é só para luz, televisão e banho quente...”; “...não pagam o medidor...”.(RIBEIRO, 1993 pp. 82/83)

Sempre com clientes mais urgentes e mais importantes, a concessionária não atendia o público rural, mas também não podia expressar formalmente que se recusava a atender a um solicitante de sua área de concessão. Seu discurso padrão era de que "a empresa sempre fazia todos os atendimentos solicitados, na forma da lei". Em suma, "forma da lei" era uma maneira polida de dizer que o interessado tinha que pagar pela obra o valor dela menos $\mathrm{R} \$ 386,88$. Queria dizer: "pagando a empresa constrói a linha". Injusto, porque o consumidor urbano não precisa pagar a extensão da rede até sua casa , conforme se verá mais adiante. (MARQUES, 2005)

Ficou evidente que as concessionárias não se interessavam pelo tema da eletrificação rural. (RIBEIRO, 1993) Pode se argumentar que seja essa uma visão de quase duas décadas passadas, que as empresas eram outras e que a maioria dos quadros técnicos se renovou. Todavia, o que move esta pesquisa é a visão deste autor de que 
parte desse quadro ainda permanece, mesmo que de forma não consciente, mesmo que aparentemente de forma mais sofisticada. Isto é o que se pretende demonstrar, nesta dissertação: o cenário da eletrificação rural no Brasil para a fase que sucederá o final do Programa Luz para Todos será composto pelas luzes da Lei da Universalização, acompanhado de um quadro sombrio na beirada da cena, trazido, de forma talvez automática, da memória das concessionárias e de seus técnicos. A dissertação proporá novas saídas que serão fundamentadas no que disse RIBEIRO, (1993), na apresentação do problema da eletrificação do pobre rural: "a eletrificação rural é uma questão politica..." ; e, mais: “a eletrificação rural é uma questão de soluções politicas".

Necessário observar que concessionária de distribuição de energia elétrica como entendemos hoje é diferente do entendimento anterior ao processo de reestruturação do setor elétrico brasileiro. No relato das pesquisas de vinte anos atrás era a forma de então se referir à empresa estatal do governo do estado, que em suas estrutura tinha as seções de geração, transmissão e distribuição. Eram seções independentes, com trabalhos totalmente diferentes. A distribuição poderia ser dividida entre uma seção de engenharia e outra de mercado, ou mercado era uma quarta seção. Essas seções normalmente pertenciam a diretorias específicas, em arcabouço administrativo de sociedade anônima. Em uma decisão da administração, ou da diretoria, da concessionária pesavam os votos colegiados de todos os diretores, das diferentes seções. O mesmo valia para as concessionárias privadas, mas quando o interlocutor se referia a elas, dado que eram de porte muito menor e restrita a mercados regionais, então ele falava textualmente "concessionária privada". As empresas que possuíam usinas, rede de transmissão ou subtransmissão, e sistema de distribuição eram chamadas de verticalizadas.

A reforma estrutural do setor elétrico brasileiro, conforme já mencionado, impôs a desverticalização das empresas. Hoje, uma concessionária de distribuição é proibida de possuir usinas geradoras ou rede de transmissão. A proibição se dá porque há conflito de interesses. A distribuidora vende no varejo a energia que compra no atacado e repassa seu custo ao consumidor. Se o comerciante que repassa custo puder comprar de si mesmo, certamente que esse custo de geração seria muito mais alto, havendo injusta transferência de renda do consumidor para o dono da geração. Por outro lado, a rede de subtransmissão hoje é considerada como ativo da 
distribuição. Então hoje, quando um texto sobre eletrificação rural fala de concessionária, está falando da distribuidora. Se for referente ao Estado de São Paulo, estará falando de uma empresa privada, pois não há participação de capital público em qualquer das distribuidoras paulistas. A rigor, o modelo previa até que a distribuidora fosse separada da empresa comercializadora de energia. Na prática, elas têm contabilidade diferente, mas vivem juntas. Assim, a administração da concessionária de distribuição atual não tem diretorias de outras atividades que não sejam pertinentes ao varejo da venda de energia e também à comercialização no atacado. Já a engenharia de distribuição se tornou quase que apenas um serviço necessário para fazer tais vendas, com muitas de suas atividades terceirizadas. Projeto e construção da eletrificação rural são realizados por empreiteiras contratadas, assim como parte dos serviços da manutenção e da comercialização. O engenheiro que hoje atua na eletrificação rural faz o planejamento, administra o trabalho de um leque de empreiteiras, comissiona a obra, contabiliza a incorporação dos ativos e entrega o consumidor para a seção comercial, para organizar o faturamento da venda de energia.

1.5.6 - A eletrificação rural sendo negada pela engenharia de distribuição

Omisso e ausente o Estado, a decisão por fazer eletrificação rural ficava com a concessionária, mais especificamente, com o setor de distribuição da empresa, que atuava voltado para os interesses maiores do capital. A definição daquilo que se entendeu como sendo um processo social, o atendimento de uma necessidade básica do cidadão, a priorização das obras e todas as decisões pertinentes, acabavam sendo responsabilidade da engenharia de distribuição, que talvez nem se desse conta da importância disso. (RIBEIRO; SANTOS, 1994)

Ela era a operadora direta e, quase sempre, única do Poder Concedente. Era a distribuição que efetivamente atendia o público, era a distribuição que detinha o poder de decidir qual rota iria tomar a linha que fornece energia, era esse setor que definia quem iria ter luz em casa, e quem iria ficar no escuro.

Afirmou o professor que coordenava as pesquisas: 
A maioria dos engenheiros do setor de distribuição tende a compreender a eletrificação rural como um processo social importante. Justamente por ser uma atividade reconhecida como de interesse social, isto faz com que muitos engenheiros se isentem da responsabilidade por um processo que, não sendo considerado prioridade técnica, não será, dessa forma, considerada da alçada de um escritório de distribuição resolvê-lo.

$O$ engenheiro tem um traço muito peculiar de procurar delimitar sua competência. É como se o mundo além da sua mesa de trabalho não lhe dissesse respeito. (RIBEIRO - 1993 p. 89)

Assim, ficou claro aos pesquisadores que a questão social não movia os engenheiros. Eficientes tecnocratas cujas preocupações ficavam em torno do retorno econômico, era de sua sensibilidade que dependia o desencadear e a definição do alcance do processo social do atendimento das famílias que ainda viviam sem energia elétrica. O mercado rural não era prioritário e só era atendido no bojo de uma posição emanada especificamente da direção da empresa, provavelmente aproveitando um dinheiro que teria vindo de fora e havia entrado marcado para esse fim (CORREIA, 1992). A afirmação retro é tomada por este autor como sendo absolutamente atual e presume-se que vale para situações nas quais a distribuidora não receba incentivo financeiro ou punição tarifária por não atendimento e assim, considere-se desobrigada. A questão social não estará moverá os técnicos da distribuição.

Como os técnicos negavam que tinham um problema de eletrificação rural para resolver? Em primeiro lugar, negavam pelo superdimensionamento do mercado rural. O consumidor rural é pobre e de baixo poder aquisitivo. A incorporação de cargas é muito lenta. Compra-se o primeiro eletrodoméstico e apenas depois das vinte e quatro suaves prestações quitadas é que se pode comprar o segundo. Adquirida a televisão, só um ou dois anos depois é que vem a geladeira. E assim vai. O engenheiro previa consumos grandes e depois convivia com a frustração do investimento ocioso, o que acarretava péssima avaliação da eletrificação rural. Em segundo lugar, negava, alegando dificuldade de manutenção, falta de confiabilidade, ou, ainda, falta de segurança. Algumas vezes, alegando falta de conhecimentos e domínio sobre uma tecnologia ainda não absorvida pela empresa, mas que poderia permitir a viabilidade do atendimento. A pesquisa é antiga, mas este autor observou todos esses itens em que eram baseados os atos de negar a eletrificação rural nos dias atuais. Hoje há um item a mais, muito utilizado pelas concessionárias atuais para não ter que fazer eletrificação de comunidades isoladas: as dificuldades com os órgãos ambientais, para obter licenciamento. Valorizar essas dificuldades é uma forma eficiente de negar o 
atendimento e tem sido usada pela distribuição atual. (RIBEIRO, 1993)

1.6 - A ruptura do dilema da eletrificação rural e o Modelo BNDES/USP

Muitos estudiosos afirmam que as concessionárias de energia não representam meios de solucionar o problema da eletrificação rural. (RIBEIRO,1993) Alguns autores relevantes propõem a criação de uma agência central com vocação para planejar projetos de desenvolvimento de longo prazo, independente das concessionárias, como forma de definir diretrizes que sejam de interesse da sociedade para a expansão do serviço de energia, tais como (MUNASHINGHE, 1987) e (FOLEY, 1992).

RIBEIRO e SANTOS, 1994, partindo do reconhecimento de que estava posto o grande dilema institucional que impedia a expansão da eletrificação rural identificado pelos estudos acima citados, publicaram na Revista do BNDES, $\mathrm{n}^{\circ} 2$, em dezembro de 1994, o artigo intitulado "Política de eletrificação rural: superando dilemas institucionais" no qual apresentaram um modelo de eletrificação rural planejado pelo BNDES e pela Escola Politécnica. Uma das bases desse modelo era, justamente, que o planejamento das ações e a gestão do programa ficassem fora das concessionárias e que seu objetivo fosse marcadamente social, ao invés de buscar retorno econômico.

A ruptura do dilema se daria pela ação política de governo, impondo a seus organismos e às concessionárias os objetivos sociais.

$\mathrm{O}$ entendimento era de que a lei exigia que o beneficiado pagasse pelas obras. O BNDES seria a fonte de um financiamento privilegiado, que seria repassado diretamente para os atendidos por um banco estadual. O BNDES oferecia recursos para quantas ligações fossem necessárias, desde que algumas condições fossem cumpridas. Entre estas, a exigência de que todos que solicitassem seu atendimento fossem atendidos pelas obras. Outra condição era que o risco bancário fosse assumido pelo governo estadual, pois eram recursos do Fundo de Amparo ao Trabalhador e a lei exigia definição clara de quem arcaria com o risco do empréstimo.

Foi realizada uma experiência com o modelo BNDES/USP no Estado de 
São Paulo, por meio do Programa Luz da Terra. O programa era carregado de inovações e enfrentou muitas resistências dentro das concessionárias do governo paulista.

CARMO, (2005), apresenta uma lista dessas inovações. Esse autor operava o Programa Luz da Terra dentro de uma concessionária privada, e, algum tempo depois, operava também o Programa Luz no Campo. Em seu trabalho de mestrado analisa que um número significativo dessas inovações foi absorvido pelo segundo programa, operado pela Eletrobras. Concluiu também que algumas diretrizes vitais para o Programa Luz para Todos faziam parte do Programa Luz no Campo, sendo que muitas delas tiveram sua origem no Programa Luz da Terra e no modelo BNDES/USP. É importante ressalvar que os dois primeiros programas exigiam que o beneficiado pagasse pelas ligações, enquanto o Luz para Todos é totalmente de graça. (CARMO, 2005)

A inovação mais importante do Programa Luz da Terra é que todos deveriam ser atendidos, independentemente de sua renda ou de seu cadastro bancário. Isso representou uma ruptura de paradigma na distribuição rural do Brasil. $O$ instrumento legal que fundamentou essa quebra de paradigma foi o decreto estadual $n^{\circ}$ 41.187, de 25 de setembro de 1996.

O modelo BNDES/USP partia do pressuposto já apresentado neste trabalho de que o dilema da eletrificação rural se manifestava em três níveis diferentes, no Estado, na administração da concessionária e no setor de distribuição e que poderia ser rompido pela vontade política de governo. Superado o dilema no nível do Estado, primeiramente pelo reconhecimento de que havia na realidade um grande problema de eletrificação rural que o Brasil deveria resolver, o próprio Estado encontraria ferramentas para impor suas diretrizes à concessionária, e depois ao setor de distribuição de energia. Esta dissertação reconhece que o arcabouço regulatório que desde o final de 1999 vem se aperfeiçoando de forma coerente e consistente, quebrando outros paradigmas - o maior deles é que a ligação ficou gratuita a todos os solicitantes representa o rompimento do dilema da eletrificação rural. A arquitetura regulatória atual faz valer efetivamente a imposição da vontade política do Governo Federal sobre as concessionárias e sobre seus técnicos, provocando como resultado a inclusão de todos 
os solicitantes.

Hoje o dilema está superado. Essas cordas de amarração regulatória, que inicialmente foram presas no marco da inauguração do Programa Luz no Campo, mas que se juntaram a outras amarradas em outros marcos legais, vão se romper no momento em que Programa Luz para Todos deixar de existir, A fotografia desse evento já mostrará uma parte de cidadãos desamarrados da regulação de Estado e no escuro. O autor reafirma sua hipótese "de que muitos elementos encontrados em 1990 na eletrificação rural das concessionárias estarão despertando de uma hibernação em 2011”, e questiona agora: haverá um novo dilema da universalização do atendimento?

1.7 - O papel das cooperativas de eletrificação rural

As cooperativas de eletrificação rural no Brasil têm sua gênese imbricada com a necessidade de se levar energia elétrica ao meio rural ou seja, com a eletrificação rural. Seria seu papel principal, justamente, fazer eletrificação rural, por meio de uma ação coletiva e organizada. (PELEGRINI, 2001)

No entanto, paradoxal e surpreendentemente, constata-se que as cooperativas, em sua maioria, não se interessavam pelo trabalho da eletrificação rural. (PELEGRINI, 2003)

As cooperativas historicamente se configuravam como um elo de ligação entre o poder local agrário e rural e o poder estatal, notadamente político, presente na estrutura do setor elétrico desde sua formação, sendo essa presença reforçada com o fortalecimento do Estado brasileiro (PELEGRINI - 2003)

O grande poderio das cooperativas ocorreu no momento em que as concessionárias ainda estavam em sua maior parte voltadas aos grandes centros urbanos. (CORREIA, 1992) O sistema cooperativista prosperou na década de 1940, principalmente no Rio Grande do Sul, com apoio político e financeiro do Ministério da Agricultura. Após 1964, financiamentos que organismos internacionais ofereciam ao regime militar foram utilizados por esse Ministério para fortalecimento das cooperativas, o que significava o fortalecimento da classe de proprietários rurais com 
carência de infraestrutura. Esse apoio foi crescendo até a década de 70, e, conforme apresentado em capítulo anterior, o Ministério da Agricultura financiou dois grandes programas de eletrificação das cooperativas, PNER I e PNER II, com recursos do BID. Também como se comentou anteriormente, surgiram grandes conflitos entre a eletrificação rural do Ministério da Agricultura - com recursos do BID - e a do Ministério de Minas e Energia - com recursos da Eletrobras. Com a consolidação do setor elétrico brasileiro esse quadro se transformou, novos conflitos de interesse surgiram e foi a partir desse momento que se pode entender melhor o papel das cooperativas na estrutura de poder de então. (RIBEIRO - 1993)

De maneira geral a estrutura de poder nas cooperativas reproduzia e reproduz a estrutura do poder local, paroquial. Assim, não era incomum que presidentes de cooperativas se tornassem prefeitos de Municípios e vice-versa, que as demandas políticas das cooperativas e de seus representantes tivessem tratamento privilegiado pelos governos estaduais e federal. Como diz PELEGRINI (2003 p. 10): "Era comum o tema das cooperativas de eletrificação rural ser tratado como uma coisa de colegas no gabinete do Ministro de Minas e Energia Engenheiro Aureliano Chaves"

Ainda hoje essa situação persiste - mesmo que modernizada pelas exigências dos tempos que mudam - e a poucos quilômetros de São Paulo. O Prefeito de Itariri é, atualmente, o presidente da Cooperativa de Eletrificação da Região de Itariri.

Do ponto de vista da regulação, é no Decreto $n^{\circ} 41.019 / 57$ que as cooperativas de eletrificação rural surgem pela primeira vez como partícipes na expansão do sistema elétrico nacional. Sua primeira regulamentação, porém, só viria cinco anos depois, no Decreto 1.033/62, que reconheceu e levou para o âmbito da regulação esses agentes.

Essa regulação estabeleceu a possibilidade de as cooperativas optarem entre se tornarem permissionárias ou concessionárias de energia, ou, ainda "na qualidade de consumidores, (...) ceder a seus cooperados energia recebida em grosso de concessionários do serviço público federal de energia elétrica”. 
O meio rural nunca foi um mercado atraente para as concessionárias que se solidificavam no mercado, mas havia, contudo, a possibilidade de um dia vir a ser. Resulta dessa visão de possibilidade de surgir um mercado de interesse a regulamentação posterior, via Decreto ${ }^{\circ}$ 62.655/68.

Exarado por um governo que se instalara e mantinha pela força e arbítrio, este decreto, que revogou o anterior, de $\mathrm{n}^{\mathrm{o}} 1.033 / 62$, visava garantir futuros mercados para o sistema de grandes empresas públicas em ascensão. A atuação das cooperativas ficava restrita à eletrificação rural e por eletrificação rural se entendeu:

\begin{abstract}
Art $1^{\circ} \dot{E}$ considerada eletrificação rural a execução de serviços de transmissão e distribuição de energia elétrica destinada a consumidores localizados em áreas fora dos perímetros urbanos e suburbanos das sedes municipais e aglomerados populacionais com mais de 2.500 habitantes, e que se dediquem a atividades ligadas diretamente à exploração agropecuária, ou a consumidores localizados naquelas áreas, dedicando-se a quaisquer tipos de atividades porém com carga ligada de até $45 \mathrm{kVA}$
\end{abstract}

Chega a espantar o nível de detalhamento daquilo que era definido como eletrificação rural, detalhamento pouco comum na prática legislativa. Verdadeira reserva de mercado. A única margem para interpretação, se é que existisse essa margem, era de, no momento em que o aglomerado excedesse os 2.500 habitantes, ou que passasse a fazer parte dos perímetros urbanos ou suburbanos, o atendimento poderia ser reivindicado pelas concessionárias, pois que deixaria de se encaixar no detalhado conceito de eletrificação rural. $\mathrm{O}$ artigo $2^{\circ}$ do decreto determinava a necessidade de autorização do Ministro das Minas e Energia para a execução de obras de transmissão e distribuição destinada ao uso privativo de consumidores rurais, individualmente ou associados, deixando claro que tal autorização não conferiria delegação de poder Público. (JUCÁ, 2007)

PELEGRINI, (2003), aponta uma outra importante contradição. Se por um lado não interessava às concessionárias a ampliação do mercado das cooperativas, por outro, não se opunham à política estatal de incentivar sua proliferação - sobretudo em alguns estados, entre eles, São Paulo, nos anos 1960/1970, considerados como “os anos de ouro" do cooperativismo - por se tratar de políticas levadas a efeito por seus próprios controladores. 
Os anos 1980 foram de refluxo dos incentivos às cooperativas de eletrificação rural. À falta de recursos estatais e financiamentos privilegiados sucede-se um processo de decadência no cooperativismo de eletrificação rural. (SANTOS,1996)

O Estado de São Paulo, que investira de forma ostensiva na criação e incentivo às cooperativas de eletrificação rural nos anos 1960/1970, assistiu na década de 1980 a redução de 33 para 17 as cooperativas em atuação.

O DAEE desmobilizou sua equipe de eletrificação rural, restando um único funcionário, que hoje integra a Fecoeresp e a representa junto ao poder público. Ainda assim, a cada troca de governo, as cooperativas de São Paulo vão em romaria ao gabinete do governador manifestar o seu apoio e pedir a permanência do funcionário. (PELEGRINI, 2003 P.28)

Situação marcante aconteceu em Minas Gerais. Interessado em captar empréstimo estrangeiro para realizar a expansão do atendimento no estado, o Governo Estadual propôs a criação de um grande número de cooperativas, modelo que era oportuno para o convencimento do cedente, pois tinha sido esse o modelo que fora introduzido nos Estados Unidos por Roosevelt, em 1935, e perdurou até o início da década de 90. Depois de embolsados os recursos, a Cemig passou a absorver sistematicamente todas as cooperativas. (RIBEIRO,1993)

Se às concessionárias, mais fortalecidas do ponto de vista econômico, não havia interesse em atender ao morador pobre das áreas rurais, não foram as cooperativas de eletrificação rural que ficaram interessadas em suprir esse papel.

Esta situação é demonstrada por PELEGRINI, (2003), ao narrar a passividade, ou melhor, a omissão das cooperativas de eletrificação rural, quando da execução do Programa Luz da Terra, no estado de São Paulo. A partir de verbas do BNDES, repassadas pelo Banco Nossa Caixa, então empresa do Estado de São Paulo, com a participação do Governo do Estado e da Universidade de São Paulo, visava atender a $100 \%$ dos moradores da área rural.

Exceto uma cooperativa, todas as demais se omitiram em 
trabalhar para ligar novas cargas, deixando no escuro do final do século XX milhares de famílias cujo atendimento não lhes daria despesas (...) por não acharem que teriam grandes vantagens econômicas em atender o pobre rural... (PELEGRINI, 2003 p. 32)

O crescimento do campo ajudou a ampliar o mercado das cooperativas, permitindo o atendimento a outro tipo de público que não só aquele estipulado pelo Decreto 62.655/68. (JUCÁ, 2007) A ausência de fiscalização quanto a esse atendimento mais rentável criou um mercado mais atraente também para as cooperativas de eletrificação rural, que se fortaleceram economicamente, em alguns casos, ou mantiveram seu pequeno universo de cooperados, em outros.

Confortavelmente abrigadas à margem da regulação, as cooperativas de eletrificação rural seguiram sem dar o devido atendimento aos pobres do meio rural e, meramente apoiando-se nas suas relações políticas nas diversas esferas, o que garantiu a manutenção de suas estruturas paroquiais de poder. (PELEGRINI, 2003)

A reforma do estado ocorrida dos anos 90 impôs que o setor elétrico se reestruturasse pelo diapasão liberal, tendo sido contratada uma consultoria inglesa para dar o tom dessas reformas. A empresa Coopers \& Librand foi quem deu o tom, afinado com o fulgor da sinfonia neoliberal. Reconheceu a necessidade de as cooperativas continuarem atuando, mas não como cooperativas, e sim como prestadoras de serviço público em regime de permissão ou autorização. (FERNANDES JR, 1999). No conjunto de recomendações apresentadas pelo consórcio britânico nada havia que efetivamente garantisse a todos o acesso ao serviço. Por outro lado, quando do processo de privatização do serviço público de distribuição de energia elétrica, a obrigatoriedade de universalizar este acesso, quando prevista contratualmente, não vinha acompanhada de metas para que tal ocorresse, salvo um ou outro caso. (FUGIMOTO, 2005).

As cooperativas teriam que optar por um desses dois regimes, que seriam regulados pela ANEEL. Permissionários poderiam atender público indistinto e seriam muito parecidos com os concessionários. Os documentos legais deixaram de prever a existência de cooperativas de eletrificação rural e passaram a prever agentes permissionários ou autorizados. No futuro não haveria mais cooperativas de eletrificação, apenas agentes prestadores de serviço público, com atividades reguladas 
pela ANEEL e, na atividade de distribuir energia elétrica, sem necessidade de qualquer vínculo com o caráter de cooperativa. (JUCÁ, 2007)

Ocorreu uma forte reação da conservadora classe de cooperativas rurais. O meio mais eficaz para essas empresas manterem o caráter de cooperativa era evitar a regulamentação prevista em lei. Antes que fossem regulamentadas como permissionárias ou autorizadas iriam permanecer como sempre estiveram, cooperativas que cobravam joias para a ligação. Prova do poder de influência política das cooperativas de eletrificação rural foi a postergação do seu enquadramento no âmbito da regulação.

1.8 - A posição das concessionárias de distribuição do serviço público de energia elétrica

Entendiam - e talvez queiram entender ainda - as concessionárias de distribuição que a exigência de participação financeira do consumidor não só era legal como também legítima.

A questão da responsabilidade pela expansão do serviço de distribuição de energia elétrica era um ponto relevante das discussões que envolviam o setor elétrico na época que foi escolhida para ser o marco inicial desta dissertação, a virada do século $\mathrm{XX}$, e foi quando entrou em cena a expressão "universalização do atendimento", que hoje é dominante, mas, divide a cena com o "atendimento pelo Luz para Todos", como se verá adiante. (RIBEIRO, 2008)

O cidadão que quisesse ter acesso ao serviço público de energia elétrica era obrigado a participar financeiramente dos custos para sua conexão. No meio urbano, com maior capilaridade do sistema de distribuição, essa participação não chegava a ser um fator inibidor de novas ligações, realidade diversa do meio rural, no qual o custo chegava a valores proibitivos, dificultando e mesmo impedindo o acesso a um serviço, cuja extensão era obrigação legal e, em alguns casos, contratual dos agentes concessionários do serviço (SOUZA, 2004).

Este tipo de exigência passou a existir a partir do Decreto $n^{\circ} 41.019$, de 
26 de fevereiro de 1957, por meio do qual se regulamentavam os investimentos da concessionária dos serviços de distribuição de energia elétrica. O artigo 139 do Decreto estabelecia o limite do investimento da concessionária em "três vezes a receita anual estimada do novo consumo, a juízo da Fiscalização”.

Em 5 de janeiro de 1990, o DNAEE editou a Portaria $n^{\circ}$ 05, por meio da qual estabeleceu o limite de participação da concessionária nas novas ligações, não admitindo investimentos acima dos limites estabelecidos, exceto para obras de programas especiais. A mesma Portaria $n^{\circ} 05$ regulamentou o uso da Tarifa Fiscal como parâmetro para se aferir o limite de investimento da concessionária para obras de expansão do sistema elétrico, estabelecendo o limite máximo de quatro tarifas fiscais para o consumidor urbano e de seis para o consumidor rural.

Este limite permaneceu vigente até o ano de 2002, quando a promulgação da Lei ${ }^{\circ} 10.438$ revogou esta participação financeira.

1.9 - A Tarifa Fiscal - limite de investimento da concessionária

A Tarifa Fiscal, cuja origem remonta ao ano de 1962, quando foi criada pela Lei $\mathrm{n}^{\mathrm{o}} 4.156$, de 28 de novembro daquele ano, tinha por finalidade servir de parâmetro para o cálculo do antigo Imposto Único de Energia Elétrica. A forma para se obter o valor da Tarifa Fiscal estava descrita no Artigo $2^{\circ}$ da Lei e seria o resultado da divisão do total de cruzeiros obtido pela soma da energia vendida no país, pelo consumo nacional em quilowatts/hora, em valores mensais. Seria estabelecida periodicamente por órgão federal e, dizia o mesmo artigo: " $\S 2^{\circ}$ A tarifa fiscal será reajustada semestralmente, com base nos dados do último mês em relação ao qual forem disponíveis informações suficientes, decorrentes de alteração no preço da energia.".

A partir de janeiro de 1996, o valor da Tarifa Fiscal ficou estabelecido em R $\$ 64,48$, deste modo, o limite de investimento das concessionárias em novas obras para extensão do sistema elétrico ficou fixado em $\mathrm{R}$ \$ 257,92 para ligações urbanas e de $\mathrm{R} \$ 386,88$ para as ligações rurais, valores que permaneceram sem qualquer reajuste até sua extinção com a revogação da Portaria $n^{0}$ 05, ocorrida com a edição pela ANEEL da Resolução nº 223, de 29 de abril de 2003. 
Quando o cidadão que morava na cidade precisava de ligação de energia em sua casa, ele precisava apenas pagar as instalações internas, incluindo o padrão de entrada. Se o solicitante morasse em área rural, a resposta para ele era o cálculo do custo da ligação - sem qualquer preocupação de reduzir os custos da eletrificação rural - com um desconto do valor de $\mathrm{R} \$ 386,88$. É oportuno informar que o custo médio típico no início do ano de 2010 gira em torno de $\mathrm{R} \$ 7.000,00$.

PELEGRINI, (2003), afirma que as concessionárias capturaram o órgão regulador da época, transformando-o em regulador de suas próprias políticas e prioridades, o que explica, entre outras coisas, a manutenção do limite de investimento, por meio da tarifa fiscal e o congelamento desta mesma tarifa por período de sete anos.

Este quadro dificultou a expansão do atendimento do serviço de energia elétrica, sobretudo nas áreas rurais, tornando-se "uma barreira para o acesso à energia elétrica no Brasil”, como afirma (FUGIMOTO, 2005 P.54). 


\section{2 - DA ILEGALIDADE DA EXIGÊNCIA DE PARTICIPAÇÃO FINANCEIRA POR PARTE DO CONSUMIDOR DO SERVIÇO PÚBLICO DE ENERGIA ELÉTRICA}

A exigência de participação financeira por parte do consumidor para conexão ao serviço de energia elétrica já foi superada pela legislação, porém, para a finalidade deste trabalho faz-se necessária uma análise da evolução legal e regulamentar que levaram à superação de alguns mecanismos e institutos até então vigentes. Necessário também analisar a postura dos agentes concessionários e do Estado, para melhor compreender o cenário onde antes se criaram barreiras financeiras para inviabilizar o acesso à eletricidade, e prospectar eventuais entraves que possam ser colocados daqui para adiante no processo de inclusão de acesso ao serviço público de distribuição de energia elétrica às pessoas pobres do meio rural brasileiro.

SOUZA, (2004), questionou com precisão a legalidade da participação financeira do solicitante, sobretudo a partir da promulgação da Constituição Federal de 1.988 e, principalmente, com a nova configuração do setor elétrico brasileiro, fundado na concessão do serviço público de distribuição de energia elétrica, com a decorrente privatização do setor, nos anos 1990. Por meio da leitura dos artigos 21, 22 e 175 demonstrou que não há previsão para a participação financeira do consumidor no custo das obras de extensão do serviço de distribuição de energia elétrica.

$\mathrm{O}$ artigo 21 da Constituição Federal trata da competência para a exploração dos serviços e instalações de energia elétrica, bem como do aproveitamento energético dos cursos de água, atribuindo tal competência à União e aos Estados onde se situarem tais potenciais. $\mathrm{O}$ artigo 22 atribui competência exclusiva à União para legislar sobre águas e energia.

O artigo 175, assim estabelece:

Art. 175. Incumbe ao Poder Público, na forma da lei, diretamente ou sob regime de concessão ou permissão, sempre através de licitação, a prestação de serviços públicos. Parágrafo único. A lei disporá sobre:

I - o regime das empresas concessionárias e permissionárias de serviços públicos, o caráter especial de seu contrato e de sua prorrogação, bem como 
as condições de caducidade, fiscalização e rescisão da concessão ou permissão;

II - os direitos dos usuários;

III - política tarifária;

IV - a obrigação de manter serviço adequado.

Conforme se verifica do mandamento constitucional, a prestação de serviços públicos, entre os quais o de distribuição de energia elétrica se insere, incumbe ao Poder Público, o qual poderá executá-lo por meio de concessão ou permissão, estabelecendo ainda a necessidade de disposição legal acerca da política tarifária e a obrigatoriedade de manter serviço adequado.

O artigo constitucional retro foi regulamentado por meio da Lei 8.987, de 13 de fevereiro de 1995. O artigo $7^{\circ}$ desta Lei, localizado no Capítulo III, sob o título DOS DIREITOS E OBRIGAÇÕES DOS USUÁRIOS resume tais direitos e obrigações, Destacam-se os incisos I e IV:

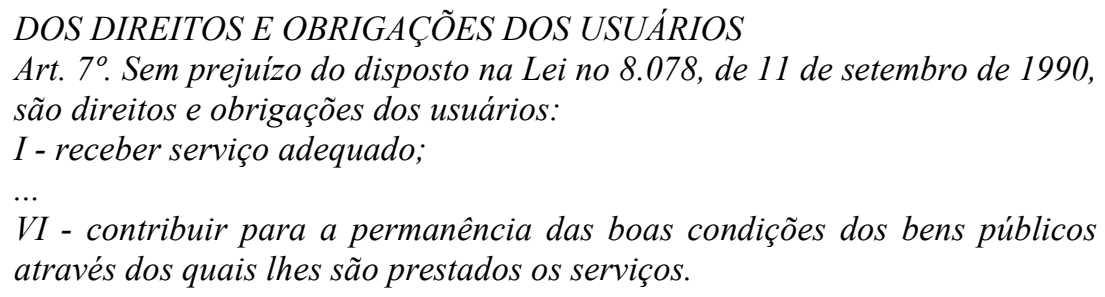

Não há nesse ou em qualquer outro artigo, qualquer previsão de participação financeira de parte do consumidor.

A política tarifária está regulamentada nos artigos $9^{\circ}$ a $13^{\circ}$, sendo de importância para este trabalho os seguintes pontos:

Art. 9o A tarifa do serviço público concedido será fixada pelo preço da proposta vencedora da licitação e preservada pelas regras de revisão previstas nesta Lei, no edital e no contrato.

$\S 2$ o Os contratos poderão prever mecanismos de revisão das tarifas, a fim de manter-se o equilibrio econômico-financeiro.

$\S 3$ o Ressalvados os impostos sobre a renda, a criação, alteração ou extinção de quaisquer tributos ou encargos legais, após a apresentação da proposta, quando comprovado seu impacto, implicará a revisão da tarifa, para mais ou para menos, conforme o caso.

$\S 40$ Em havendo alteração unilateral do contrato que afete o seu inicial equilíbrio econômico-financeiro, o poder concedente deverá restabelecê-lo, concomitantemente à alteração.

Art. 10. Sempre que forem atendidas as condições do contrato, considera-se 
mantido seu equilibrio econômico-financeiro.

Art. 13. As tarifas poderão ser diferenciadas em função das características técnicas e dos custos especificos provenientes do atendimento aos distintos segmentos de usuários.

Também nesta lei, nenhuma citação à participação financeira do consumidor para que tenha acesso ao serviço público. Apenas admite-se, no artigo 11 em seu parágrafo único, “[..] a possibilidade de outras fontes provenientes de receitas alternativas, complementares, acessórias ou de projetos associados, com ou sem exclusividade, com vistas a favorecer a modicidade das tarifas..."

É de se salientar que tal possibilidade visa a manutenção da modicidade tarifária, portanto em favor do consumidor, nada prevendo em termos de sua participação financeira.

No Capítulo VI, sob o título DO CONTRATO DE CONCESSÃO, o artigo 23, que trata das cláusulas essenciais do contrato também não estabelece ou prevê a participação financeira do consumidor, para a obtenção do serviço público, pelo contrário, o inciso $\mathrm{V}$ do artigo estabelece como uma das cláusulas essenciais do contrato de concessão aquelas relativas:

\footnotetext{
$V$ - aos direitos, garantias e obrigações do poder concedente e da concessionária, inclusive os relacionados às previsiveis necessidades de futura alteração e expansão do serviço e consequente modernização, aperfeiçoamento e ampliação dos equipamentos e das instalações;
}

Ficando claro a quem cabe a responsabilidade pela ampliação do fornecimento. Tão claro que esse inciso encontra-se separado daquele que trata dos “direitos e deveres dos usuários para obtenção e utilização do serviço”, exposto no inciso VI.

Deste modo, não há como negar a separação entre a obrigação de ampliação do serviço público e sua responsabilidade das obrigações do consumidor do serviço público de energia elétrica. 
A previsão de participação do consumidor, que ficou estabelecida depois da reestruturação do setor elétrico brasileiro é exclusivamente a existente no inciso III do artigo 14 da Lei ${ }^{\circ}$ 9.427, de 26 de dezembro de 1996, que instituiu a ANEEL, tal como segue:

\begin{abstract}
Art. 14. O regime econômico e financeiro da concessão de serviço público de energia elétrica, conforme estabelecido no respectivo contrato, compreende:

I - a contraprestação pela execução do serviço, paga pelo consumidor final com tarifas baseadas no serviço pelo preço, nos termos da Lei $n^{\circ} 8.987$, de 13 de fevereiro de 1995;

II - a responsabilidade da concessionária em realizar investimentos em obras e instalações que reverterão à União na extinção do contrato, garantida a indenização nos casos e condições previstos na Lei $n^{\circ}$ 8.987, de 13 de fevereiro de 1995, e nesta Lei, de modo a assegurar a qualidade do serviço de energia elétrica;

III - a participação do consumidor no capital da concessionária, mediante contribuição financeira para execução de obras de interesse mútuo, conforme definido em regulamento;
\end{abstract}

Pelo que se vê do texto legal a participação financeira do consumidor: (1) depende de definição em regulamento, (2) será restrita à execução de obras de interesse mútuo e (3) será convertida em participação no capital da concessionária. Desse modo, é indiscutível que a cobrança de participação financeira prévia do cidadão no custo das obras que lhe garantirão o acesso ao serviço público de distribuição de energia elétrica é totalmente descabida.

Necessário ressalvar que a Lei $\mathrm{n}^{\mathrm{o}} 10.438 / 2002$, no $\S 5$, do artigo 14 , prevê a possibilidade de participação financeira do consumidor, na forma de adiantamento a ser ressarcido, como transcrito a seguir:

\footnotetext{
§ 5o A ANEEL também estabelecerá procedimentos para que o consumidor localizado nas áreas referidas no inciso II do caput possa antecipar seu atendimento, financiando ou executando, em parte ou no todo, as obras necessárias, devendo esse valor lhe ser restituido pela concessionária ou permissionária após a carência de prazo igual ao que seria necessário para obter sua ligação sem ônus.
}

Não se trata de participação financeira, mas sim de antecipação a ser ressarcida, portanto totalmente diferente da regulação antecedente, que não previa qualquer tipo de ressarcimento. 
Em capítulo anterior, relembrou-se que RIBEIRO, (1993), tratando da relação da concessionária com o problema da eletrificação rural afirmava que a maneira de a concessionária resolver o problema da eletrificação rural era negando a sua existência. $\mathrm{O}$ autor concluiu que aquelas empresas não tinham interesse em resolver o problema do acesso do pobre rural à luz elétrica e, mais, os engenheiros de distribuição negavam que fosse correta a participação de fato de suas empresas na eletrificação rural para público-alvo pobre a partir de um viés ideológico, vigente tanto no Brasil, como em muitos outros países em desenvolvimento. Quando se exige de um solicitante uma importância que lhe é proibitiva para confirmar sua solicitação, ele naturalmente desiste de se cadastrar como tal. Logo, a distribuidora fica sem registro de possuir solicitante algum, negando que exista para si um problema de eletrificação rural. 


\section{3 - RESISTÊNCIAS À UNIVERSALIZAÇÃO DO ATENDIMENTO DE 2002}

O ano 2000 trouxe a Eletrobras ao centro do cenário da eletrificação rural. Ao apresentar o Programa Luz no Campo para o governo de São Paulo em maio de 2000, o Ministro de Minas e Energia conceituou o atendimento social que o programa propunha como uma peça necessária ao modelo liberal de reforma do Estado dos anos 1990. Segundo ele, o longo processo de retirada do Estado de atividades como infraestrutura de serviços públicos, transferindo-as à livre iniciativa competitiva, trazia muitos ganhos ao mercado e eram benéficas à sociedade porque os custos dos serviços iriam inexoravelmente baixar. Todavia, o modelo liberal reconhecia que as parcelas mais pobres da população não alcançariam benefícios e ficariam desguarnecidas da proteção que tinham do Estado. A iniciativa privada tem por objetivo capitalizar lucros e não arcaria com as antigas obrigações do Estado. Então, para manter um cenário social que permitisse ao mercado alcançar seus objetivos com tranquilidade, teria que haver compensações sociais que buscassem manter o equilíbrio da sociedade como um todo. (CARMO, 2005)

As compensações sociais eram previstas pelo modelo que o governo da época decidira impor como parte intrínseca desse modelo que previa a privatização total do setor elétrico. Bancos e grupos financeiros internacionais passaram a se posicionar para assumir o comando das empresas do setor. (CARMO, 2005)

Discutiam-se formas de se ganhar mais dinheiro. Os "banqueiros de olho azul" tentaram impor, por exemplo, que o governo vendesse todas as usinas geradoras arcaicas, porque eles traziam inovações tecnológicas maravilhosas por meio das usinas térmicas a gás natural. Quem fosse mais competente é que venceria a competição do mercado e a sociedade seria a grande vitoriosa. Esses senhores não admitiam a concorrência dessa energia velha dos elefantes brancos que diziam ser as grandes hidrelétricas do Brasil, porque o custo marginal da operação dessas usinas tocada pela água da chuva não abria espaço para que seus modelos de desregulação completa pudessem render todas suas potencialidades. A operação em cascata das usinas, instaladas nas grandes bacias brasileiras permitia um adicional de uso de energia de $25 \%$ com a operação centralizada do fluxo da água. O Brasil tinha décadas de experiência de guardar água no reservatório de Furnas e Ilha Soleira, usando-a meses 
depois para mover as turbinas de Itaipu, que funciona a fio de água. Sabia transferir energia de uma bacia para outra. Esses banqueiros não sabiam que se podia fazer isso eram de países onde não há mais água para aproveitar ou onde não se transfere energia e questionavam tudo em nome do melhor rendimento para seus capitais. (CARMO, 2005)

O Programa Luz no Campo não foi do agrado de muitos setores empresariais que poderiam aproveitar de forma muito mais rentável os fundos que eram movimentados. Houve reação negativa a partir do setor de concessionárias de distribuição. Também houve tentativa de menosprezar a atitude social que o Governo Federal, por meio do Ministério de Minas e Energia e da Eletrobras impunham de forma decidida por parte dos grandes consumidores industriais. O porta-voz dos consumidores energo-intensivo criticava na imprensa a interferência do governo no setor elétrico pela insistência com o "Programa Luz no Campo, que só existia porque era a menina dos olhos do ministro Tourinho..." (TOURINHO, 2000)

Um ponto que foi muito questionado e que também, ainda hoje é negado por representantes do empresariado do setor elétrico, é a discussão de que a energia elétrica não é considerada um serviço público essencial. Esta dissertação prevê que tal interposição excludente recrudesça a partir de 2011 e possa servir de argumento para as distribuidoras negarem a necessidade de fazer o atendimento universal em situações onde elas entendam que não estão correndo risco de punição. Então, decide-se que é oportuno fazer aqui tal discussão. Por motivos análogos, este trabalho também faz a análise da energia elétrica enquanto direito do consumidor e como ela se relaciona com o Direito Ambiental. 


\section{4 - A ENERGIA ELÉTRICA COMO SERVIÇO PÚBLICO ESSENCIAL}

O estudo que se faz a seguir decorre de trabalho anterior do autor desta dissertação, quando em Mestrado na área de Direito. As conclusões aqui apresentadas estão mais detalhadas no trabalho referido.

Não há pessoa que discorde da essencialidade da energia elétrica. Chega a ser quase intuitivo o entendimento de que ninguém pode hoje viver sem acesso à energia elétrica.

É senso comum, também, que o acesso à energia elétrica significa conforto, saúde, possibilidade de acesso à informação, dignidade etc.

SAUER; ROSA; D’ARAÚJO, (2003) afirmam:

energia elétrica pode ser encarada como fator de promoção da qualidade de vida, de produção, desenvolvimento econômico e de geração de emprego e renda. A exclusão social também se dá por falta de acesso a energia. $O$ desenvolvimento tecnológico, ao passo que traz benefícios à humanidade, aumenta a distância entre os sem e os com energia. (SAUER; ROSA; D’ARAÚJO, 2003 p. 39)

Para além da intuição ou do senso comum, porém, o sistema legal brasileiro permite verificar essa essencialidade na prestação do serviço público de distribuição de energia elétrica.

A Constituição Federal não diz expressamente que a energia elétrica seja um serviço público essencial, É justamente nesse ponto em que se fiam alguns para dizer que essencial é a energia para produção e não essencial é a energia das comunidades pobres e sem possibilidade de consumo apreciável. Mas, pela análise sistêmica e infraconstitucional poder-se-á ter esse entendimento, e por diferentes vias.

No artigo $1^{\mathrm{o}}$ do texto constitucional, que trata dos fundamentos da República do Brasil, estão estabelecidas, nos incisos II e III, respectivamente, a cidadania e a dignidade da pessoa humana.

Como se falar em cidadania e dignidade da pessoa humana se houver 
exclusão de qualquer natureza no acesso a um serviço público essencial, como é o caso da energia elétrica?

E energia elétrica é serviço essencial.

O artigo $9^{\circ}$ da Constituição Federal estabeleceu: “É assegurado o direito de greve, competindo aos trabalhadores decidir sobre a oportunidade de exercê-lo e sobre os interesses que por meio dele defender."

O parágrafo primeiro do artigo retro, assim determina: “A lei definirá os serviços ou atividades essenciais e disporá sobre o atendimento das necessidades inadiáveis da comunidade."

Deixou o constituinte de 1988 a cargo do legislador infraconstitucional a tarefa de definir quais os serviços ou atividades essenciais e necessidades inadiáveis da comunidade.

A lei $n^{\circ} 7.783$, que regulamentou o direito constitucional de greve, promulgada em 28 de junho de 1989, em seu artigo $10^{\circ}$ assim estabeleceu: "São considerados serviços ou atividades essenciais: I - tratamento e abastecimento de água; produção e distribuição de energia elétrica, gás e combustiveis."

Portanto, a partir da promulgação da lei referida, o serviço de distribuição de energia elétrica é considerado atividade essencial, assim definido pela via da infraconstitucionalidade.

A Lei $\mathrm{n}^{\circ}$ 9.074, de 7 de julho de 1995, em especial no artigo $3^{\circ}$, inciso IV, garante o atendimento das áreas rurais, ao vetar "exclusão das populações de baixa renda e das áreas de baixa densidade populacional inclusive as rurais”, do mercado a ser atendido pela concessionária ou permissionária de serviço público.

FUGIMOTO, (2005), chama a atenção para o conceito de generalidade, presente no parágrafo $1^{\circ}$ do artigo $6^{\circ}$ da Lei 8.987, de 13 de fevereiro de 1995, como uma das condições a ser atendida para que se possa considerar tal prestação como 
"serviço adequado", aponta, ainda, o dever do Estado em "garantir as condições necessárias para que o serviço de energia elétrica possa ser acessível”, em face de deter a titularidade do Poder Concedente. (FUGIMOTO, 2005)

4.1 - Energia elétrica e direito do consumidor

Conforme já citado anteriormente, é o artigo 175, da Constituição Federal que prevê o sistema de concessão ou permissão de serviços públicos, dentre os quais, o serviço de público de distribuição de energia elétrica.

O parágrafo único do artigo referido estabelece que:

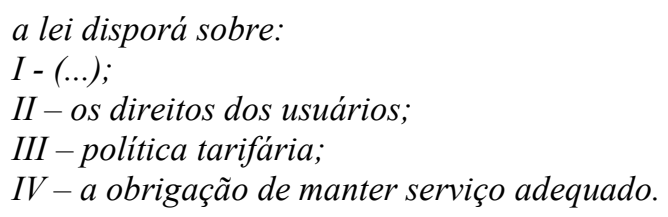

A Lei $n^{\circ} 8.987$ de 13 de fevereiro de 1995 incorporou as determinações constitucionais, ao regulamentar o dispositivo constitucional. Os artigos $6^{\circ}$ e $7^{\circ}$ tratam do Serviço Adequado e dos Direitos e Obrigações do Usuário.

O parágrafo $1^{\circ}$ do artigo $6^{\circ}$ conceitua Serviço Adequado, como segue: "Serviço adequado é o que satisfaz as condições de regularidade, continuidade, eficiência, segurança, atualidade, generalidade, cortesia na sua prestação e modicidade das tarifas."

$\mathrm{O}$ artigo $7^{\circ}$, antes mesmo de tratar do seu tema específico, alerta para a aplicabilidade do Código de Defesa do Consumidor, nas relações entre usuários e fornecedores do serviço público de energia elétrica, nos termos seguintes: "Sem prejuízo do disposto na Lei $n^{\circ} 8.078$, de 11 de setembro de 1990, são direitos e obrigações dos usuários.”

Resulta inequívoca a inclusão na categoria de consumidores os usuários dos serviços de distribuição de energia elétrica, eis que a relação que se estabelece é nitidamente de consumo, tanto na conceituação de consumidor quando na de 
fornecedor, nos termos dos artigos $2^{\circ}$ e $3^{\circ}$ da Lei $n^{\circ} 8.078 / 90$, conforme segue:

Art. $2^{\circ}$ Consumidor é toda pessoa física ou jurídica que adquire ou utiliza produto ou serviço como destinatário final.

Parágrafo único. Equipara-se a consumidor a coletividade de pessoas, ainda que indetermináveis, que haja intervindo nas relações de consumo.

Art. $3^{\circ}$ Fornecedor é toda pessoa física ou jurídica, pública ou privada, nacional ou estrangeira, bem como os entes despersonalizados, que desenvolvem atividade de produção, montagem, criação, construção, transformação, importação, exportação, distribuição ou comercialização de produtos ou prestação de serviços.

$\S 1^{\circ}$ Produto é qualquer bem, móvel ou imóvel, material ou imaterial.

$\S 2^{\circ}$ Serviço é qualquer atividade fornecida no mercado de consumo, mediante remuneração, inclusive as de natureza bancária, financeira, de crédito e securitária, salvo as decorrentes das relações de caráter trabalhista.

Mais ainda, a Lei $\mathrm{n}^{\circ} 8.078 / 90$, em seu artigo 22 garante ao consumidor de serviços públicos o direito a receber serviços adequados, eficientes, seguros e contínuos, quando se tratarem de serviços essenciais, como se vê:

Art. 22. Os órgãos públicos, por si ou suas empresas, concessionárias, permissionárias ou sob qualquer outra forma de empreendimento, são obrigados a fornecer serviços adequados, eficientes, seguros e, quanto aos essenciais, contínuos.

Parágrafo único. Nos casos de descumprimento, total ou parcial, das obrigações referidas neste artigo, serão as pessoas jurídicas compelidas a cumpri-las e a reparar os danos causados, na forma prevista neste código.

NUNES, (2004), afirma que:

como a figura do consumidor, em larga medida, equipara-se à do cidadão, todos os princípios e normas constitucionais de salvaguarda dos direitos do cidadão são também, simultaneamente, extensivos ao consumidor pessoa física. Dessarte, por exemplo, os princípios fundamentais instituídos no art. $5^{\circ}$ da Constituição Federal são, no que forem compativeis com a figura do consumidor na relação de consumo, aplicáveis como comando normativo constitucional. (NUNES, 2.004 p. 25)

Além de sua natureza consumerista, na relação entre usuárioconsumidor/fornecedor, a energia se configura como bem ambiental.

\section{2 - Energia elétrica e Direito Ambiental}

A energia, inclusive a elétrica, pode ser gerada a partir de fontes diversas. De acordo com suas características, essas fontes são classificadas como primárias ou 
secundárias, renováveis ou não renováveis (FIORILLO, 2007).

Qualquer que seja sua fonte, a energia é resultado da apropriação e transformação de fontes presentes na natureza, sendo, deste modo, um dos elementos que compõe o meio ambiente natural.

Juridicamente, o conceito de meio ambiente é: “...o conjunto de condições, leis, influências e interações de ordem física, química e biológica, que permite, abriga e rege a vida em todas as suas formas.", conforme estabelecido no artigo $3^{\circ}$, da Lei $n^{\circ} 6.938 / 81$, recepcionada pela Constituição Federal. Da leitura da Constituição Federal e da legislação infraconstitucional pode-se subdividir os aspectos do meio ambiente em:
a) meio ambiente natural;
b) meio ambiente artificial;
c) meio ambiente cultural;
d) meio ambiente do trabalho.

Essa subdivisão abrange desde os elementos presentes na natureza de forma independente da presença humana até o ambiente de desenvolvimento de atividade laboral ou da produção arquitetônica, características da ação humana.

Diante disso, sabe-se que tanto bens corpóreos quanto incorpóreos compõem o meio ambiente, portanto, não há porque se excluir a energia da categoria de bem ambiental, porquanto ao resultar da ação sobre elementos ambientais, caracterizase ela própria como bem ambiental. Sendo bem ambiental, a energia é tutelada juridicamente, conforme estabelecido pela Constituição Federal. Desde o Decreto 23.501/33, a utilização das fontes hídricas de geração de energia encontra-se sob tutela do Estado brasileiro.

FIORILLO, (2007), ao tratar do tema da tutela da energia, afirma que:

a energia é um bem ambiental tutelado na forma do que estabelece a Constituição da República e balizada através de normas infraconstitucionais (...), conforme suas diferentes formas visando o aproveitamento das 
chamadas "fontes de energia".

A Carta Magna, no art. 20, estabeleceu que, além dos recursos ambientais gerenciados pela União (vide incisos I a XI), também merecem sua tutela jurídica (art. 20, VIII) os chamados potenciais de energia hidráulica.

Analisando-se o Direito Ambiental e Direito do Consumidor, à luz dos direitos estabelecidos no Título II, Capitulo I, nos Direitos e Garantias Individuais e Coletivas, bem como os Direitos do Consumidor, no art. 5, XXXII e no art. 225 verifica-se a existência de identidade entre ambos.

Tratam-se de direitos de terceira geração, relacionados aos interesses e conflitos de massa exigindo, do ponto de vista material e instrumental, solução jurídica compatível com a sua natureza, por outro lado, são direitos de incidência transversa aos demais ramos do Direito e de assento constitucional expresso.

A titularidade indeterminada de tais direitos apresenta-se como o ponto de maior relevância no que tange à identidade existente entre Direito Ambiental e Direito do Consumidor. Tanto a titularidade do Direito Ambiental quanto do Direito do Consumidor encontram-se na coletividade de pessoas indetermináveis, estão dispersas pela sociedade de maneira difusa.

O interesse albergado em tais bens e direitos não é nem público nem privado, é meta-individual, cabendo à Administração Pública, tão somente, o dever de fiscalizar e administrar. Sendo bem ambiental, tutelado pelo Direito Ambiental, sua natureza difusa está presente no princípio do acesso de todos, presentes e futuras gerações, conforme o caput do artigo 225 da Constituição Federal, pois é bem de "de uso comum do povo" cabendo a todos o “...dever de defendê-lo e preservá-lo para as presentes e futuras gerações."

Em resumo, significa dizer: acesso garantido pelo Direito Ambiental e qualidade da prestação do serviço garantida pelo Direito do Consumidor. 


\section{5 - ANÁlise DO MOMENTO QUE ANTECEDEU A LEI DA UNIVERSALIZAÇÃO}

Neste ponto do trabalho algumas constatações devem ser registradas, pois se referem àquelas que definem a situação em que se encontrava o processo histórico da eletrificação rural no momento em que começou a amadurecer sua mais importante ruptura.

A primeira constatação que se apresenta é a total ilegalidade e inconstitucionalidade da exigência de participação financeira por parte do consumidor do serviço público de distribuição de energia elétrica, além do regular pagamento da tarifa. Toda e qualquer despesa ou custo necessário à ampliação da rede, à implementação de novas ligações, tanto na área rural quanto na área urbana, é de responsabilidade do Poder Concedente, ou do Agente Concessionário, não sendo devida qualquer participação por parte do consumidor, admitindo-se somente a antecipação dos custos, com ressarcimento posterior.

A segunda constatação é de que não basta a existência de condições financeiras e normativas para se garantir o atendimento do consumidor pobre do meio rural, pois há uma ideologia no setor da distribuição de energia elétrica refratária a esse tipo de atendimento. Dessa ideologia compartilham tanto as grandes concessionárias quanto as pequenas cooperativas tornadas permissionárias do serviço público de distribuição de energia elétrica.

A terceira constatação é de que se chegou ao final do Século XX, com o setor elétrico já possuindo as condições regulatórias necessárias à concretização do mais amplo acesso ao serviço público de distribuição de energia elétrica. Sem discutir o significado do termo, o marco legal do Programa Luz no Campo já oficializava a expressão universalização do atendimento. Antigos e históricos entraves foram sendo gradativamente superados. Novas interpretações para paradigmas existentes levaram à superação desses mesmos paradigmas, abrindo a possibilidade de um processo de efetiva universalização do acesso e uso do serviço público de distribuição de energia elétrica. O Programa Luz no Campo previa-o para alguns estados, inicialmente. Todavia, não estava em pauta ainda a questão da gratuidade das ligações. Para tanto, 
faltava a efetiva vontade política.

Como quarta constatação pode ser apontada a possibilidade de uma fonte de recursos endógena, ou seja, o próprio setor elétrico. O universo existente de consumidores do sistema pode sustentar o processo de universalização nas camadas mais pobres da população rural brasileira do serviço público de distribuição de energia elétrica, com participação do Poder Público para garantir a modicidade tarifária e o equilíbrio econômico-financeiro. Essa fonte de obtenção de recursos afasta a necessidade de busca de créditos externos ou de comprometimento exclusivo dos orçamentos públicos, em todas as suas esferas.

Uma quinta constatação, e das mais importantes, é que o Estado brasileiro reconheceu a necessidade de atendimento em nível universal de todos e de cada um dos brasileiros.

A sexta constatação diz respeito à caracterização do serviço público de distribuição de energia elétrica como um serviço essencial, reconhecido como tal pela legislação infraconstitucional, como direito do consumidor e como direito ambiental que, portanto, deve ser garantido a todos, às atuais e futuras gerações. 


\section{6 - DA ELETRIFICAÇÃO RURAL DE 2000 À UNIVERSALIZAÇÃO DE 2002}

Anteriormente foi registrado que a literatura sobre eletrificação rural era influenciada pelos avaliadores e consultores do Banco Mundial além de carregar o vício desenvolvimentista das agências multilaterais da Guerra Fria, sempre com o objetivo de controlar as políticas internas dos países do eixo ocidental. Os aspectos sociais eram meramente secundários, considerados subprodutos que deviam ser registrados, mas o que interessava eram os resultados econômicos.

Terminado o ciclo de abundância de financiamento externo para o Terceiro Mundo e com a mudança da situação política global, os programas de eletrificação rural baseados em políticas de ampliação dos sistemas elétricos de potência deixaram de existir e a literatura percebeu essas mudanças. Surgiu nesse mesmo tempo de mudanças globais o "boom" dos sistemas fotovoltaicos. Houve financiamentos, principalmente nos países de Terceiro Mundo, de grandes programas com geração fotovoltaica. A literatura trouxe um viés de modernidade tecnológica com forte apelo ecológico, procurando abrir novos mercados para equipamentos derivados da física do estado sólido, cujos produtores globais eram empresas dos países mais ricos. O tema de que a energia renovável evita a poluição do ambiente tornou-se ideológico, a ponto de muitos autores ignorarem que o Brasil move suas tomadas com água dos rios, também renovável. Autores, inclusive brasileiros, falavam que a energia solar fotovoltaica deveria ser preferida para a eletrificação rural como a melhor forma de preservação do meio ambiente. Havia um falso conflito no trato do tema da comparação econômica entre o atendimento por rede ou por fotovoltaicos, a partir de que distância o sistema fotovoltaico seria mais viável que o atendimento por rede. Essa dúvida de fato existe, mas não é o valor dessa distância que vai resolver o problema da eletrificação rural no Brasil ainda que muitos estudos tenham se restringido ao estudo da dúvida sobre a distância. (RIBEIRO, 2010)

A importância do atendimento social surgiu com força na literatura depois que os mesmos organismos internacionais passaram a valorizar esses aspectos. Os pesquisadores Fernando Selles Ribeiro e Luiz Henrique Pazzini contam que, surpresos com uma abordagem fortemente social em uma palestra de um consultor do BID na Conferencia Latinoamericana de Electrificación Rural de 2001, em San Jose, na 
Costa Rica, abordaram o expositor para manifestar essa surpresa de ver a valorização da cidadania como objetivo desse tipo de investimento. A resposta era que o BID tinha uma nova orientação de começar a apoiar-se nesses aspectos para abrir novos mercados para os fornecedores, pois havia identificado um nicho relativo aos itens de pequenos sistemas fotovoltaicos domiciliares e minirredes em regiões carentes de todos os serviços públicos e, consequentemente, de cidadania. Nesse sentido, valorizar a energia como fonte de cidadania poderia sensibilizar os planejadores de políticas de desenvolvimento social.. (RIBEIRO, 2009)

BARROS, (1999), identifica que o termo "universalização do atendimento" surgiu com as discussões havidas durante a fase de formação da Comunidade Européia. As diferentes economias resolveram que iriam fundir-se a partir de parâmetros comuns a todas. Ao explicitar o trato que elas davam ao atendimento dos serviços públicos, ficou claro que todas atendiam, porém, com procedimentos distintos. $\mathrm{Na}$ França, o serviço público era estatal, baseado no governo federal. Na Alemanha, estatal, baseado em governos regionais. Na Inglaterra, totalmente privado, $\mathrm{Na}$ Itália, misto. Então, a fusão partiria do princípio formalizado do atendimento universal a todos os cidadãos do respectivo país. A autora ainda revela que o serviço que mais demandava essas discussões era o da telefonia, que na época vivenciava a revolução da chegada dos celulares. Também, diz ela, foram os celulares que trouxeram este termo ao Brasil no final do século passado, na mesma onda neoliberal que criou o Mercado Comum Europeu. (BARROS, 1999)

O modelo BNDES/USP propôs o atendimento a 100\% dos pobres rurais no Estado de São Paulo, em 1996. Já foi relatada a forte resistência por parte dos técnicos de distribuição das concessionárias que o achavam ilegítimo, porque atendia a interesse externo à empresa e inoportuno por provocar prejuízo nos seus projetos. Todavia, a universalização do atendimento chegou aos debates do setor elétrico e isso aconteceu por meio dos técnicos da área de concessões da ANEEL.

PAZZINI, (2001), registrou que, mesmo oficializado esse termo, ainda não estava definido o significado real desse conceito. RIBEIRO, (2003), identifica que essa mesma época marca a tendência de substituição do jargão "eletrificação rural” pelo 
novo "universalização do atendimento".

\section{7 - ESTABELECENDO NOVOS PARADIGMAS}

Do ponto de vista legal e constitucional, já havia o entendimento e os pressupostos para se viabilizar o amplo acesso ao serviço público de distribuição de energia elétrica no meio rural brasileiro, em especial para eliminar os níveis de exclusão nos estratos de mais baixa renda do campo brasileiro. Mudanças teriam que acontecer para que se verificasse na prática o que já se sabia possível e já fora preparado no campo legal, mas que ainda precisava de uma ponte para se transferir e se sustentar no campo da regulação econômica de energia elétrica.

Os meios acadêmicos passaram a discutir a universalização do atendimento. Em evento realizado na Unicamp no, quase sempre, qual esse tema estava em discussão, a ANEEL apresentou um esboço de proposta. Também, em Audiência Pública promovida pela própria Agência para tratar da regulamentação das cooperativas, o conceito de universalização do atendimento permeava as discussões. Para registrar, o Governo Estadual do Rio Grande do Sul mandou a essa audiência sua Secretária de Energia Dilma Roussef, tal fato representa o apoio que o Governo Estadual dava ao conjunto de cooperativas de eletrificação rural. (RIBEIRO, 2008)

No mês de junho de 2002, no Hotel Blue Tree Park, em Brasília, sob o patrocínio do Ministério de Minas e Energia, do Banco Mundial e do Programa das Nações Unidas para o Desenvolvimento (PNUD), aconteceu o workshop Estratégias para Eletrificação Rural no Brasil - Workshop para discussão de opções.

Reunindo nomes ligados aos órgãos oficiais do setor elétrico, da área da agricultura, defesa etc., bem como representantes de organizações não governamentais, federações e confederações de classe, representantes de concessionárias de energia elétrica e do meio acadêmico com atuação na área, o evento discutiu a eletrificação rural sob os mais diversos aspectos. (ESMAP, 2002)

No convite à participação no evento, os organizadores indicavam que o mesmo fazia parte de 
um estudo em desenvolvimento pelo Programa de Assistência ao Gerenciamento do Setor Elétrico (ESMAP), que visa identificar opções estratégicas para o suprimento de energia elétrica das áreas rurais do Brasil, através de tecnologias que utilizam fontes renováveis de energia, onde forem economicamente viáveis. (ESMAP,2002)

Como objetivos do evento elencavam quatro itens:

1. Ativar o diálogo entre os atores chave;

2. Obter maiores informações sobre problemas práticos relacionados à eletrificação rural no Brasil;

3. Apresentar um relatório preliminar sobre a estratégia de eletrificação rural adotada até então;

4. Discutir diferentes estratégias de eletrificação rural com base em opções viáveis. (ESMAP, 2002)

Ainda de acordo com o documento encaminhado aos convidados, o projeto "Brasil: Estratégia de Eletrificação Rural" tinha por objetivo: "formular uma ampla estratégia de eletrificação rural em nível nacional, buscando uma definição do papel do governo e do setor privado, bem como de outros agentes locais e nacionais, neste processo." (ESMAP, 2002)

Indicava, também, a existência de cerca de 14 milhões de pessoas, divididas em 60 mil comunidades sem acesso à eletricidade, sendo este número correspondente a $32 \%$ da população rural brasileira. (ESMAP, 2002)

O temário preliminarmente apresentado aos participantes propunha a discussão de temas como "qualidade da luz", acerca da melhoria resultante da substituição da fonte de luz de velas, querosene ou pilhas pela luz elétrica; "educação e informação", a respeito da possibilidade de melhoria na educação em casa e na escola, pela chegada da energia elétrica; "efeitos na saúde" tratando tanto da possibilidade de centros de saúde e hospitais na área rural até a melhoria da qualidade da água; "atividades comunitárias", tratando de atividades culturais, políticas e sociais; "aspectos de gênero", indicando a transformação na vida de mulheres e crianças, "benefícios para os grupos de baixa renda"; "tecnologias de energias renováveis"; "incentivo à intervenção governamental", entre outros. (ESMAP, 2002)

É interessante apontar que esses textos ainda falam de eletrificação rural 
e não falam de universalização do atendimento. Certamente preparados com antecedência, esses documentos não registraram a ruptura capital da eletrificação rural, acontecida um mês antes.

7.1 - O pacto entre agentes econômicos, Estado e sociedade

SANTOS, (2004), analisa a desarrumação que o racionamento de 2001 impôs à sociedade brasileira, em particular, aos agentes do setor elétrico. As empresas que tinham contratos baseados em lei que lhes garantia o equilíbrio-econômico financeiro, em abril e maio de 2001 passaram a recomendar aos seus clientes que eles deviam reduzir o consumo de seu único produto e ainda multar quem continuasse a comprar além do limitado. O governo solicitou à fornecedora que vendesse menos energia e ao consumidor que comprasse menos, provocando consensualmente o desequilíbrio financeiro, sobrestando o contrato de concessão.

Um ano depois, superado o episódio do racionamento de energia elétrica com um histórico de ampla compreensão e solidariedade de todos os segmentos sociais, era o momento de recompor o equilíbrio econômico-financeiro das distribuidoras. Discutiam-se, no Congresso Nacional, formas de oferecer vantagens compensatórias, entre as quais, empréstimos privilegiados com recursos do BNDES. Tais vantagens interessavam muito aos agentes econômicos, mas, estavam além do ponto de compensação. Estava quase pronto um grande acordo do setor elétrico na forma de um projeto de lei, faltava ajustar essa compensação em excesso. O relator do projeto de lei era um deputado do partido mais conservador, professor de engenharia de distribuição e ex-diretor de duas concessionárias estatais. Recebeu uma sugestão de oferecer a universalização do atendimento como contrapartida das distribuidoras e mandou sua assessoria imediatamente redigir a proposição, a qual foi aceita pelos agentes econômicos sem muita discussão, pois esses ainda percebiam que lhes era interessante a compensação. O Projeto foi aprovado com ampla maioria e foi sancionado pelo Presidente da República dias depois. (SANTOS, 2004)

A Lei $n^{\circ} 10.438$, de 26 de abril de 2002, tem nos seus artigos $n^{\circ} 13, n^{\circ} 14$, $\mathrm{n}^{\mathrm{o}} 15$ e $\mathrm{n}^{\mathrm{o}} 18$ marcos revolucionários. Para o setor elétrico e para este trabalho, é conhecida como Lei da Universalização do Atendimento. 
7.2 A Lei $n^{\circ} 10.438$, de 26 de abril de 2002

A Lei $\mathrm{n}^{\mathrm{o}} 10.438$ de 26 de abril de 2002, representa o momento de quebra de paradigma mais significativo, na medida em que prepara o ambiente regulatório para que seja implantado um programa que de fato poderia atender a toda a população rural brasileira. É esse diploma legal que vai determinar a gratuidade do atendimento, naquele momento ainda sob a égide da Resolução $n^{\circ} 456 / 00$, com todas as suas limitações. Seus pontos essenciais estão nos artigos 13, 14, 15 e 18. É no artigo 14 que está estabelecida a gratuidade do atendimento, especificamente nos incisos I e II, como segue:

Art. 14. No estabelecimento das metas de universalização do uso da energia
elétrica, a ANEEL fixará, para cada concessionária e permissionária de
serviço público de distribuição de energia elétrica:
"I - áreas, progressivamente crescentes, em torno das redes de distribuição,
no interior das quais a ligação ou aumento de carga de consumidores deverá
ser atendida sem ônus de qualquer espécie para o solicitante;
II - áreas, progressivamente decrescentes, no interior das quais a ligação de
novos consumidores poderá ser diferida pela concessionária ou
permissionária para horizontes temporais pré-estabelecidos pela ANEEL,
quando os solicitantes do serviço serão então atendidos sem ônus de
qualquer espécie.

Já o artigo 15 trazia a possibilidade de outorgar permissões de serviço público de energia elétrica, em área nas quais o agente concessionário ou permissionário não tivesse cláusula de exclusividade em seu contrato. Trata-se de verdadeira possibilidade de intervenção, para se atingir a universalização do atendimento:

Art. 15. Visando a universalização do serviço público de energia elétrica, a ANEEL poderá promover licitações para outorga de permissões de serviço público de energia elétrica, em áreas já concedidas cujos contratos não contenham cláusula de exclusividade

O artigo 18 é de importância crucial, pois prorroga o prazo da RGR, Reserva Geral de Reversão, até o ano de 2010. Criada pelo Decreto no 41.019, de 26 de fevereiro de 1957, a RGR tem por objetivo a compensação por ativos não depreciados, no caso de término ou revogação da concessão. Em fevereiro de 1999, a ANEEL revisou a cobrança do RGR determinando que todas as distribuidoras e determinadas geradoras que operam sob regime de serviço público fizessem contribuições mensais ao Fundo RGR a uma taxa anual equivalente a 2,5\% dos ativos imobilizados da empresa 
em serviço, até um teto de $3 \%$ do total das receitas operacionais em cada ano. A prorrogação do prazo para a extinção da RGR foi de fundamental importância para a viabilização do Programa Luz para Todos.

$\mathrm{O}$ artigo 13 é o que criou a $\mathrm{CDE}$ - Conta de Desenvolvimento Energético:

\begin{abstract}
Art. 13. Fica criada a Conta de Desenvolvimento Energético - CDE, visando o desenvolvimento energético dos Estados e a competitividade da energia produzida a partir de fontes eólica, pequenas centrais hidrelétricas, biomassa, gás natural e carvão mineral nacional, nas áreas atendidas pelos sistemas interligados e promover a universalização do serviço de energia elétrica em todo o território nacional, devendo seus recursos, observadas as vinculações e limites a seguir prescritos, se destinarem às seguintes utilizações
\end{abstract}

Criada para estabelecer competitividade às fontes de energia não convencionais, tais como pequenas centrais hidrelétricas, eólicas etc., pouco mais de um ano depois, tornou-se fundamental fonte de recursos para custear a universalização, integrando a planilha de custos como subvenção, a fundo perdido, sendo o mecanismo que propicia a manutenção da modicidade tarifária e do equilíbrio econômicofinanceiro.

O texto legal remeteu à ANEEL a obrigação de regulamentar a Lei da Universalização no prazo de um ano.

Ainda no decorrer do ano de 2002, o Conselho Nacional de Política Energética, órgão que assessora diretamente a Presidência da República, criou uma comissão para estudar as consequências desse novo paradigma, preparando a regulamentação da Lei ${ }^{\circ}$ 10. 438. Assim, foi instalado o GT7 - Grupo de Trabalho $n^{\circ} 7$ - Universalização do Serviço de Energia.

Esse Grupo de Trabalho reuniu diversos segmentos da sociedade para discussões acerca da aplicação da Lei da Universalização do Atendimento. Ficou muito clara a pretensão das empresas concessionárias que tentavam adiar o máximo possível as metas de universalização do atendimento, sugerindo o horizonte do ano de 2025. (RIBEIRO, 2008) 
Alguns membros do GT $\mathrm{n}^{\circ} 7$ assumiam posições de resistência, além das distribuidoras. Eram propostos critérios de atendimento, como distância da rede, densidade, entre outros. Cobrava-se do Governo uma definição imediata do mercado que deveria ser atendido, quem cobrava sabia que esse mercado era impossível de ser quantificado. Os representantes das universidades presentes conseguiram impor e sustentar que o mercado era "todo mundo", de modo que não havia porque definir qualquer outro critério. A distância da rede também foi chamada para dar parâmetros ao atendimento por sistemas fotovoltaicos. O professor Roberto Zilles, do IEE-USP, teve a sabedoria de acabar com esse conflito acerca da distância que torna o fotovoltaico viável ao propor que o atendimento com sistemas solares fotovoltaicos deveria começar pelos lugares muito mais distantes da rede, e não próximos a ela onde não haveria dúvida alguma sobre que opção seria mais viável. Uma extensa discussão se deu sobre as fontes de financiamentos e os prazos para a conclusão do processo. (RIBEIRO, 2010)

O GT $n^{\circ} 7$ participou intensamente da disputa pela utilização da CDE, entre vários grupos de interesse, tais como os empresários da geração eólica e, principalmente de carvão mineral. O GT n.7 deixou de ser convocado no final do ano de 2002. A regulamentação da Lei $n^{0} 10.438$ deixou de ser aberta e ficou por conta do novo Governo. Em abril de 2003, a ANEEL promoveu uma Audiência Pública para discutir uma proposta de resolução de regulamentação. Dias depois, publicou a Resolução $\mathrm{n}^{\mathrm{o}} \mathrm{n}^{\mathrm{o}}$ $223 / 03$.

7.3 - A Resolução n 223 , de 29 de abril de 2003

Em 29 de abril de 2003 foi publicada pela ANEEL a Resolução n 223, que estabelecia "as condições gerais para elaboração dos Planos de Universalização de Energia Elétrica visando ao atendimento de novas unidades consumidoras com carga instalada de até $50 \mathrm{~kW}$. Por meio desta resolução a ANEEL estabeleceu as condições gerais para a elaboração dos Planos de Universalização das concessionárias e permissionárias.

Os artigos $3^{\circ}$ e $4^{\circ}$ estabelecem a gratuidade do atendimento limitado a carga instalada menor ou igual a $50 \mathrm{~kW}$. A resolução, no artigo $6^{\circ}$, determina prazos 
para que as concessionárias e permissionárias apresentem seus Planos de Universalização. Estabelece, ainda, no $\S 2^{\circ}$, em caso de não apresentação de Plano de Universalização, o início imediato do atendimento gratuito, o que somente ocorreria, no caso de apresentação do referido Plano, a partir do ano de 2.004. No artigo $14^{\circ}$ estão previstas as penalidades para o caso de não atendimento das metas acumuladas. As penalidades se dão por meio da aplicação de redutores aos índices de reajustes quando da revisão tarifária.

É na publicação da Resolução n ${ }^{\circ} 223$ que se dá efetivamente a revogação da Portaria $\mathrm{n}^{\mathrm{o}} 5$ do DNAEE e se instaura a gratuidade do atendimento, que será aperfeiçoada sete meses depois, por meio da Lei ${ }^{\circ} 10.762$, de 11 de novembro de 2003, que criou o Programa Luz para Todos.

O Programa Luz no Campo, em 1999, e o advento da Lei $n^{\circ} 10.438$, em 2002, trouxeram a necessidade de novas discussões acerca do acesso à energia elétrica pelo morador pobre das áreas rurais.

Do acúmulo de conhecimento que vem desde os primórdios das discussões sobre eletrificação rural até aquele ano de 2002, acrescidos de uma visão política não tradicional do novo Governo na gestão da República ou, como preconizara RIBEIRO, dez anos antes, em 1993 “...a grande barreira a ser vencida é o custo da instalação. Um povo empobrecido não tem como pagá-lo. Porém, um governo que realmente esteja empenhado em inserir em sua política de desenvolvimento econômico os segmentos mais carentes da nação deve, e pode fazê-lo”(RIBEIRO, 1993, p. 61), formaram-se as condições para se chegar a um programa de inclusão energética que trazia em si os pressupostos exaustivamente discutidos e reivindicados pelos estudiosos e defensores do acesso incondicional de todos os moradores pobres do meio rural brasileiro. 


\section{8 - O PROGRAMA LUZ PARA TODOS}

Em 11 de novembro de 2003 foi publicada a Lei $n^{\circ} 10.762$, juntamente com o Decreto $\mathrm{n}^{\mathrm{o}} 4.873$, que a regulamentava. A Presidência da República promoveu uma solenidade no Palácio do Planalto com a presença da maioria dos Governadores de Estado, autoridades do Poder Legislativo, Ministros de Estado, agentes econômicos do setor elétrico e muitos convidados para lançar o Programa Luz para Todos.

O Programa Nacional de Universalização do Acesso e Uso da Energia Elétrica ou, simplesmente, Programa Luz para Todos traz em sua estrutura uma somatória de conhecimentos e propostas estudadas e discutidas ao longo dos vários anos da eletrificação rural no Brasil.

Em particular, foram expostos aos técnicos que preparavam as regras do Programa Luz para Todos dentro do Ministério de Minas e Energia os resultados de alguns trabalhos de pesquisas que servem de base para este trabalho. PELEGRINI (2003), em sua tese de doutorado intitulada “A regulação das cooperativas de eletrificação rural", identifica o que chamou de uma sombra no arcabouço regulatório, impedindo que a regulação do setor elétrico alcance os cidadãos sem energia, carentes dos efeitos da Lei da Universalização, que viviam dentro das áreas já delimitadas das cooperativas. Essa Lei supra citada obriga "concessionárias e permissionárias" a atender gratuitamente dentro de metas temporais específicas. As cooperativas, como ainda não haviam sido regularizadas como permissionárias, não eram alcançadas por essa obrigação pela qual o legislador pretendeu que todos os cidadãos fossem incluídos no atendimento. Outra falha regulatória foi identificada pela dissertação de mestrado de FERNANDER Jr, (1999), que diz respeito ao conceito de atendimento de propriedade, hoje regulada pela Resolução ANEEL nº 456 de 2000. Nas propriedades agrícolas e de produção de leite, a energia chega à casa do fazendeiro e vai até o centro de produção, o curral. Dali partem linhas sem qualquer cuidado técnico ou de segurança que vão até as casas mais próximas dos colonos que trabalham no leite e moram dentro da propriedade, como é o costume nacional nessa atividade econômica. Não pagando pela energia, os colonos não podem de nada reclamar, ou seja, não estão abrigados pelo sistema regulatório. $\mathrm{O}$ autor verificou péssima regulação nessas casas, chegando medir 70 volts quando a família deveria receber 127 volts, como qualquer outra família cuja 
instalação esteja sob a regulação da ANEEL. Também, identificou um problema social: essas famílias se cansam de ter geladeiras, televisores e outros eletrodomésticos danificados. Sem alternativas para evitar esses prejuízos, sentem-se forçadas a sair da área rural para viver na cidade, onde é possível ver televisão, mas não se tem o emprego garantido. Fazendo extrapolação, esse trabalho identifica que havia alguns milhões de cidadãos brasileiros convivendo com energia emprestada, de baixa qualidade e sem ter a quem recorrer. Comentando que o setor elétrico prefere conviver com o costume de iluminar a Casa Grande e deixar a Senzala no escuro, o autor propôs que a solução deveria contemplar outro Ponto de Entrega dentro da propriedade rural. (FERNANDES $\mathrm{Jr}, 1999)$ :

...as casas de colonos ou estão isoladas umas das outras e distantes do ponto
de entrega ou estão agrupadas e distantes do medidor de energia. Muitas
vezes estão mais próximas da rede de distribuição da concessionária do que
do ponto de entrega. Portanto, um novo ponto de entrega parece ser uma
alternativa bastante interessante. ... Mesmo que isso represente custo mais
elevado, estaria sendo garantido um bom padrão de fornecimento de
energia, com manutenção da concessionária. (FERNANDES Jr.1999 P.141)

Outro trabalho apresentado ao Ministério foi a dissertação de Osvaldo Tadami Arimura, intitulada "A escola pública sem energia elétrica em São Paulo", defendida em 1999, que demonstra a necessidade de uma priorização específica para a eletrificação das escolas rurais. (RIBEIRO, 2009)

Saber incorporar e implementar essas características, além de todas as demais inovações necessárias, em um único programa de governo e ter vontade política de fazê-lo foram os grandes avanços trazidos pelo Programa Luz para Todos, avanços que tornam impensável e cruel a sua descontinuidade.

As características básicas do Programa Luz para Todos podem ser verificadas a partir da leitura da legislação pertinente, em especial do Manual de Operacionalização, em suas várias versões.

Para o objetivo deste trabalho optou-se pela versão mais recente do Manual, a Revisão $n^{0}$ 6, de 22 de fevereiro de 2009, anexa à Portaria $n^{0} 85$, do Ministério de Minas e Energia, embora o estudo comparado das alterações ocorridas desde a primeira versão até a Revisão de $n^{0} 6$ possa oferecer um bom tema de estudo. 
É justamente no conteúdo de cada uma dessas alterações, em sequência temporal, que estão os itens de aprimoramento do modelo brasileiro de eletrificação rural, culminando com a consolidação do Programa Luz para Todos, na sua forma atual, conforme está na revisão $n^{\circ} 6$, acrescida do Manual de Projetos Especiais, em fevereiro de 2009.

A ser ressaltado no Manual de Projetos Especiais, destinado ao atendimento de situações que exigem projetos especiais, pois "as localidades a serem atendidas encontram-se distantes das redes de distribuição de energia elétrica, de dificil acesso e especialmente para o transporte de materiais e equipamentos e normalmente com baixa densidade populacional”, demandando utilização de fontes “de geração de energia descentralizada, pequenos trechos de redes de distribuição em tensões primária elou secundária - mini-rede”, que o atendimento deverá garantir, conforme o item 5.1.5 do Manual, "a potência mínima capaz de atender às necessidades básicas dos domicílios (iluminação, comunicação e refrigeração).

Isto garante o mínimo de conforto a ser garantido em atendimentos não convencionais.

A primeira característica a ser notada está no primeiro parágrafo da introdução do Manual de Operacionalização do Programa Luz para Todos, que reproduz diretrizes do Decreto $\mathrm{n}^{\circ} 4.873$, de 11 de novembro de 2003, como segue:

O Decreto no 4.873, de 11 de novembro de 2003, alterado pelo Decreto no 6.442, de 25/04/2008, instituiu oPrograma Luz para Todos, destinado a propiciar, até o ano de 2010, o atendimento em energia elétrica à parcela da população do meio rural brasileiro que ainda não tem acesso a esse serviço público.

De acordo com art. 30 do Decreto, o Programa será coordenado pelo Ministério de Minas e Energia - MME e operacionalizado com a participação das Centrais Elétricas Brasileiras S.A. - ELETROBRÁS e das empresas que compõem o Sistema ELETROBRÁS.

Ainda nos termos do art. 7o do Decreto, deverá o Ministério de Minas e Energia editar esse "Manual de Operacionalização do Programa e demais normas pertinentes à sua execução." 
Verifica-se então que o Programa Luz para Todos é um programa voltado para a "parcela da população do meio rural brasileiro que ainda não tem acesso a esse serviço público." Mais ainda, verifica-se que a operacionalização do Programa se dá com a participação da Eletrobras e a coordenação está a cargo do Ministério de Minas e Energia a quem incumbe, ainda, elaborar e editar o Manual de Operacionalização, bem como demais as normas pertinentes, para nortear a execução do Programa.

No item 2 do Manual fica estabelecido o atendimento exclusivo a domicílios e estabelecimentos localizados no meio rural.

No item 4.1 define-se que o Programa

\begin{abstract}
objetiva garantir o acesso ao serviço público de energia elétrica à parcela da população do meio rural brasileiro que ainda não possui acesso a esse serviço público; melhorar a prestação de serviços à população beneficiada, intensificar o ritmo de atendimento e mitigar o potencial impacto tarifário, por meio da alocação de recursos subvencionados e pelo complemento de recursos financiados.
\end{abstract}

No mesmo item está declarado que o Programa Luz para Todos atuará de forma integrada aos diversos programas sociais e de desenvolvimento rural tanto do Governo Federal quanto dos Governos Estaduais: "para assegurar que o esforço de eletrificação do campo resulte em incremento da produção agrícola, proporcionando o crescimento da demanda por energia elétrica, o aumento de renda e a inclusão social da população beneficiada."

Nos termos do item 4.2 do Manual, os agentes executores do Programa são "as concessionárias e permissionárias de distribuição de energia elétrica e as cooperativas de eletrificação rural autorizadas pela Agência Nacional de Energia Elétrica - ANEEL" e, em casos excepcionais, as empresas do sistema Eletrobras, responsáveis pela operacionalização do Programa, poderão exercer as funções de agente executor.

No segundo parágrafo do mesmo item fica estabelecido que, para a otimização dos recursos, será priorizado "o atendimento com tecnologia de rede de 
baixo custo e, de forma complementar, com sistemas de geração descentralizada com rede isolada e sistemas individuais."

Necessário ressaltar que o Programa Luz para Todos, por meio do Manual de Operacionalização, ao incluir entre os Agentes Executores as cooperativas de eletrificação rural, resolve uma limitação anterior, atribuindo responsabilidades e atribuições, ao mesmo tempo em que garante o acesso às fontes financeiras do programa.

O terceiro parágrafo explicita que:

o Programa destinará recursos a projetos que visem ao atendimento de futuros consumidores situados no meio rural, e privilegiará o caráter social do investimento. A distribuição dos recursos setoriais (Conta de Desenvolvimento Energético - CDE e Reserva Global de Reversão - RGR) baseia-se principalmente na necessidade de mitigar os impactos tarifários das diversas áreas de concessão, nas carências regionais e na contrapartida financeira oferecida pelos Estados e Agentes Executores.

A meta do Programa está expressa no item 4.3, como sendo de 2 milhões de novos atendimentos, até o ano de 2008, com prorrogação até 2010 para o atendimento de novas demandas.

O item 4.5 trata da tipificação das fontes dos recursos, estabelecendo que parte destes virá de dois fundos setoriais - CDE e RGR, sendo um deles na forma de subvenção econômica (a fundo perdido) e outro como financiamento.

Além dos fundos setoriais prevê a participação de Estados e Municípios (na forma de subvenção econômica) e da contrapartida de parte do agente executor. $\mathrm{Na}$ solenidade de lançamento, cada Governador, inclusive o de São Paulo, assinou um Termo de Adesão, comprometendo-se com a parceria e com o fornecimento de recursos como contrapartida, no valor, mínimo, de $10 \%$ dos custos totais, no caso do Estado de São Paulo.

Necessário destacar que em nenhum momento se cogitou da participação do solicitante, do cidadão a ser atendido com qualquer parcela que seja. 
Essa é uma das características mais marcantes e de maior importância do Programa Luz para Todos: a gratuidade do acesso ao serviço público de distribuição de energia elétrica.

O item 5 do Manual trata da estrutura organizacional do Programa Luz para Todos, organizado do seguinte modo:

$\rightarrow$ Comissão Nacional de Universalização, coordenado pelo Ministério de Minas e Energia, que tem por atribuição o estabelecimento de "políticas e diretrizes para o uso da energia elétrica como vetor de desenvolvimento integrado no meio rural”.

$\rightarrow \quad$ Ministério de Minas e Energia, cujas atribuições, entre outras, são coordenar oPrograma Luz para Todos e estabelecer as políticas para as ações do Programa.

$\rightarrow \quad$ Comitê Gestor Nacional-CGN; Coordenadores Regionais, representados pela ELETRONORTE, CHESF. ELETROSUL e FURNAS, que tem entre suas atribuições a missão de "atuar no sentido de prover estrutura física e logística aos CGEs nas respectivas regiões elétricas", inclusive contratando e capacitando os Agentes Luz para Todos.

$\rightarrow \quad$ Comitês Gestores Estaduais - CGEs, com um total previsto de nove membros titulares, incluindo o Coordenador, que tem como atribuições "avaliar as demandas da sociedade e definir as obras de eletrificação rural a serem priorizadas segundo os critérios estabelecidos neste Manual", elaboração e encaminhamento de relatórios à Coordenação Regional, atuar como facilitador para o atendimento das metas por parte dos agentes executores, acompanhamento da execução física e financeira das obras nos Estados e a identificação e articulação de "ações de desenvolvimento rural integrado que possibilitem o uso social e produtivo da energia elétrica".

$\rightarrow$ ELETROBRÁS, responsável pela análise dos planos de obras, assinatura de contrato e liberação de recursos e fiscalização de sua correta aplicação.

$\rightarrow \quad$ Agentes Executores, responsáveis pela execução das obras - concessionárias, permissionárias e autorizadas. 
$\rightarrow \quad$ Agentes Luz para Todos, que atuam diretamente no campo, em contato direto com a população alvo do Programa, subordinados ao Coordenador do Comitê Gestor Estadual.

O Manual apresenta ainda os critérios para a definição de prioridades das obras, os critérios técnicos de atendimento, as condições para liberação de recursos, as condições financeiras dos contratos, condições de financiamento da RGR, entre outras definições e critérios.

Da análise destes aspectos e critérios encontrados no Manual de Operacionalização do Programa Luz para Todos, as características do Programa podem ser sintetizadas do seguinte modo:

1. É um programa subvencionado - para a concessionária, em parte, para o consumidor, integralmente - dirigido à parcela de moradores da área rural sem atendimento pelo serviço de distribuição de energia elétrica.

2. Os atendimentos são efetuados sem necessidade de contrapartida financeira por parte do atendido.

3. Possui uma estrutura descentralizada, envolvendo atores diversos, com atribuições específicas, que representam setores do poder público da sociedade civil e da iniciativa privada.

4. Procura integração com outros programas locais e regionais, para desenvolvimento de ações visando à utilização da energia como vetor de desenvolvimento.

5. Os critérios, tanto técnicos quanto para a priorização de obras, estão definidos e elencados de forma clara. 
6. Do ponto de vista regulatório, está no âmbito do setor elétrico, a partir da definição do Ministério de Minas e Energia como coordenador e responsável pelas normas gerais e específicas.

7. Tem previsão de atendimento estabelecido pelo Censo do IBGE2000 e prazo definido para atingir a meta.

Necessário, neste ponto, abrir um espaço para falar do Agente Luz para Todos, pela importância de sua atuação em campo, imprescindível para o sucesso do Programa.

A fim de melhor se inserir nas comunidades rurais o Programa Luz para Todos trouxe à cena um ator essencial: o Agente Luz para Todos, cuja atuação está regulada pelo Manual de Operacionalização, no item 5.8.1.

Nos termos do Manual, as atribuições do Agente Luz para Todos são:

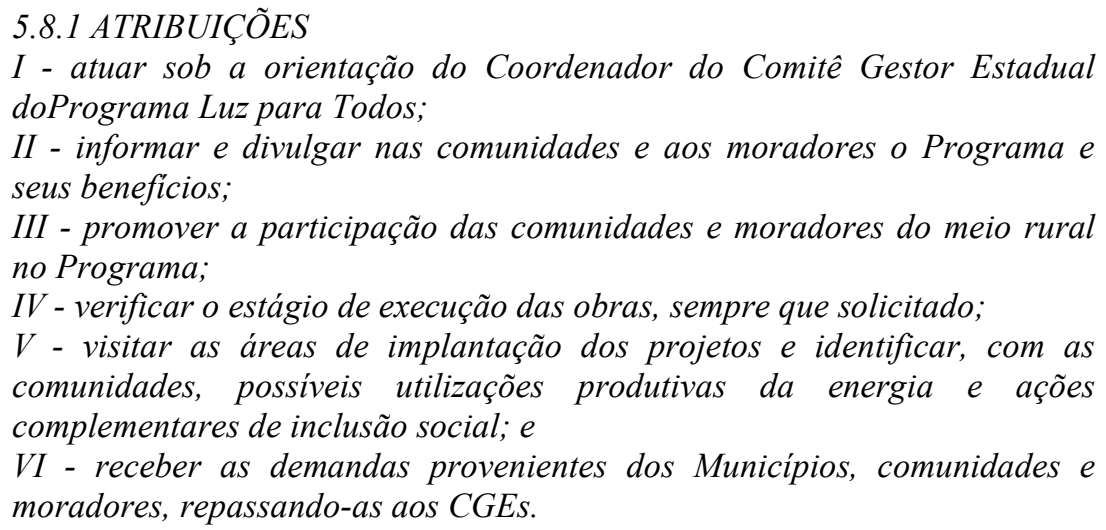

É previsto que os agentes estabeleçam relações com órgãos públicos locais tais como Prefeituras, Casas de Agricultura entre outros, além de relações com outros órgãos do Governo Federal, tais como Ministérios, bem como com agentes e executores de outros programas governamentais.

Outra relação que se estabelece é com colegiados locais resultantes da própria organização das comunidades ou da aplicação de programas diversos, exemplos de tais colegiados são os CONSAD - Consórcios de Segurança Alimentar e 
Desenvolvimento Local, CONSEA - Conselho Nacional de Segurança Alimentar e Nutricional - CONDRAF - Conselho Nacional de Desenvolvimento Rural Sustentável e mais recentemente, os Territórios da Cidadania, entre outros.

A principal relação, contudo, se dá com as comunidades para as quais o Agente dirige seu trabalho. Nessas comunidades, o Agente desenvolve atuação diversificada, ora como facilitador nas relações entre as comunidades e os agentes executores, agentes gestores de programas diversos, ora atuando como uma liderança ativa, que identifica e, se necessário, participa da construção de outras lideranças, para que as atividades tenham continuidade, ou seja, tornem-se sustentáveis.

$\mathrm{Na}$ verdade todas estas relações se misturam e confundem permanentemente e delas decorrem outras relações não claramente estabelecidas, todas elas decorrentes da prática dentro das normas estabelecidas pelo Manual de Operacionalização.

$\mathrm{Na}$ relação com outros Ministérios e Programas, bem como com prefeituras e órgãos locais, o que se estabelece é uma relação de natureza política, não no sentido partidário, mas na acepção de administração de conflitos e da busca comum de soluções, no sentido de buscar a integração dos recursos para otimizar sua aplicação e melhor atender às comunidades.

$\mathrm{Na}$ relação com as comunidades é que se dá o momento mais rico da atuação do Agente. A diversidade de possibilidades e necessidades colocada obriga a um nível de envolvimento que, via de regra, ultrapassa a mera atividade profissional e entra para o campo da ação direta sobre a realidade objetiva.

Em comunidades com maior complexidade de organização, o papel do agente é mais o de interlocutor privilegiado com os demais órgãos federais, com a empresa executora, o poder instituído, bem como, em certos casos, seu papel é de interpretar e equalizar os anseios de grupos organizados ou de lideranças em conflito em uma mesma comunidade.

Nas comunidades com menor grau de organização o Agente acaba 
desempenhando o papel de viabilizar demandas de diversas naturezas, buscando identificar possíveis líderes e incentivando a organização dessas comunidades.

Em qualquer dos casos, o Agente se envolve com os órgãos colegiados locais, participa das discussões, encaminha propostas, integra esses mesmos colegiados, participando de suas discussões e buscando identificar as suas características e necessidades, para fazer a integração com o Programa Luz para Todos.

Assim, a atuação do Agente se expande em ação e significado, abrangendo, no mínimo:

- Levantamento das reais demandas das comunidades atendidas.

- Identificação de lideranças.

- Incentivo às ações organizativas.

- Encaminhamento de demandas interministeriais e das diversas esferas de governo.

- Participação nos foros locais e regionais de desenvolvimento territorial e de redução da pobreza e geração de renda.

- Proposição e encaminhamento de ações integradas em conjunto com as comunidades.

Essas ações somente são possíveis por que, de forma diversa à visão dos agentes executores, que está centrada no aspecto técnico em conjunção com o financeiro, o Agente Luz para Todos possui uma dupla visão no processo da eletrificação rural enxergando-a como uma questão política e uma demanda social.

Quando se fala em questão política, entre outros fatores, temos que considerar que o Programa Luz para Todos, possui uma característica que é comum aos programas de eletrificação rural, ou seja, o resultado obtido vai além da inclusão energética.

Em sua atuação o Agente acaba revelando discrepâncias sociais, tais como as relativas a conflitos fundiários, restrições ambientais, aspectos organizacionais e aspectos culturais entre outros. Ao mesmo tempo, possibilitando a aplicação de outros 
programas de inclusão, aumento e/ou geração de renda, podendo levar a transformações qualitativas da comunidade atendida.

Por outro lado, a decisão de se investir dinheiro do público a fundo perdido ou não, atender a toda a população excluída ou parte dela, investir apenas o suficiente para acender a luz e ver TV ou para incentivar a produção agrícola etc. são aspectos que vão determinar qual o projeto político e qual a política de governo estão em andamento. Serve também para avaliar o nível de dominação do Estado aos interesses empresariais do setor, identificando qual política é constitucional e qual fere preceito fundamental.

Em função destas características, nestes cerca de sete anos de Programa Luz para Todos, graças à atuação dos Agentes Luz para Todos pode-se verificar:

- Levantamento de uma demanda imprevista pelo CENSO IBGE/2000.

- Aprimoramento dos programas locais de atendimento às comunidades rurais.

- Aumento das interfaces entre programas federais e estaduais.

- Aumento da interface entre órgãos federais e estaduais.

- Transformações nos critérios de atendimento do Programa Luz para Todos.

- Maior eficácia do atendimento às comunidades rurais.

A atuação dos Agentes do Programa Luz para Todos está em plena consonância com o que estabelece o Manual de Operacionalização que rege o Programa.

No item 4.1, que trata dos objetivos do Programa está assim estabelecido:

Manual de Operacionalização doPrograma Luz para Todos

\subsection{Objetivos}

...oPrograma Luz para Todos se integra aos diversos programas sociais e de desenvolvimento rural implementados pelo Governo Federal e pelos Estados, para assegurar que o esforço de eletrificação do campo resulte em incremento da produção agrícola, proporcionando o crescimento da 
demanda por energia elétrica, o aumento de renda e a inclusão social da população beneficiada.

O Manual apresenta ainda os critérios para a definição de prioridades das obras, os critérios técnicos de atendimento, as condições para liberação de recursos, as condições financeiras dos contratos, condições de financiamento da RGR, entre outras definições e critérios.

Buscando uma frase que resuma tais características, pode-se dizer que o Programa Luz para Todos é: um programa de eletrificação rural, dirigido à parcela residente no meio rural brasileiro, sem atendimento do serviço público de energia elétrica, com meta temporal e de quantidade de atendimento, coordenado pelo Ministério de Minas e Energia e executado pelas empresas de distribuição do setor elétrico, parcialmente subvencionado, que não exige nenhuma contrapartida financeira de parte do solicitante atendido.

Necessário esclarecer que algumas de suas características não são invenções do Programa Luz para Todos, decorrem de um acúmulo de experiências que levaram à possibilidade de se chegar a tal estrutura, com uma "pedra de toque" fundamental que é não haver necessidade de qualquer contrapartida de parte do cidadão pobre, residente na área rural, excluído do serviço público de distribuição de energia elétrica.

A grande inovação é ter tido a efetiva vontade política de lançar mão do conhecimento e das experiências acumuladas para levar energia a todos os moradores da área rural, em especialados mais pobres, sem distinção nem contrapartida.

8.1 - A transferência da competência normativa

O primeiro aspecto que chama a atenção na estrutura do Programa Luz para Todos é que o Decreto $\mathrm{n}^{\circ} 4.873$, que o institui, estabelece uma transferência da competência normativa da Agência Nacional de Energia Elétrica - ANEEL para o Ministério de Minas e Energia. 
Instituída pelo artigo $1^{\circ}$ da Lei $\mathrm{n}^{\circ} 9.427$, de 26 de dezembro de 1996, a Agência tem suas atribuições principais estabelecidas no artigo $2^{\circ}$ :

Art. $1^{\circ}$ É instituída a Agência Nacional de Energia Elétrica - ANEEL, autarquia sob regime especial, vinculada ao Ministério de Minas e Energia, com sede e foro no Distrito Federal e prazo de duração indeterminado.

Art. $2^{\circ}$ A Agência Nacional de Energia Elétrica - ANEEL tem por finalidade regular e fiscalizar a produção, transmissão, distribuição e comercialização de energia elétrica, em conformidade com as políticas e diretrizes do governo federal.

Ao estabelecer no artigo $7^{\circ}$ que o "Ministério de Minas e Energia deverá, no prazo de trinta dias, editar o manual de operacionalização do Programa e demais normas pertinentes à sua execução" o Decreto $\mathrm{n}^{\circ} 4873 / 03$ suspende a aplicabilidade das normas existentes para que passem a valer aquelas editadas pelo Ministério de Minas e Energia, bem como transfere da ANEEL para o MME a competência para estabelecer as normas relativas às ligações resultantes do Programa Luz para Todos.

Nesse sentido, na hipótese de haver comandos contraditórios entre as normas da Agência e o que for normatizado pelo Ministério de Minas e Energia em relação a ligações decorrentes do Programa Luz para Todos, deverão prevalecer as editadas pelo MME, em detrimento do escopo regulatório da ANEEL.

Esta característica foi de suma importância para o amplo atendimento efetuado pelo Programa, pois, a legislação que instituiu o Programa Luz para Todos suspendeu alguns dos critérios e normas em vigência, em especial aqueles estabelecidos na Resolução $\mathrm{n}^{\circ} 456 / 00$, tratada adiante, que seriam impeditivos ao amplo acesso ao serviço público de distribuição de energia elétrica, conforme veremos. 


\section{9 - A RESOLUÇÃO N 456 DE 29 DE NOVEMBRO DE 2000}

Com o objetivo de "rever, atualizar e consolidar as disposições referentes às Condições Gerais de Fornecimento de Energia Elétrica, visando aprimorar o relacionamento entre os agentes responsáveis pela prestação do serviço de energia elétrica e os consumidores" em 29 de novembro de 2000, a ANEEL fez publicar a Resolução $n^{\circ} 456$.

Para sua elaboração, duas audiências públicas foram realizadas, uma em 10 de fevereiro de 1999 (Audiência Pública ANEEL nº 007/98 - Condições de Fornecimento para Iluminação Pública) e outra em 5 de novembro do mesmo ano (Audiência Pública ANEEL no 007/99).

Com 125 artigos, a Resolução trata desde definições de carga instalada, consumidor e concessionária até especificidades da iluminação pública, na busca por abranger todo o espectro das Condições Gerais de Fornecimento de Energia Elétrica.

No âmbito deste trabalho alguns artigos dessa Resolução configuram-se como foco do interesse. São eles os artigos $2^{\circ}, 3^{\circ}$ e $9^{\circ}$.

O artigo $2^{\circ}$, que trata das "definições", em especial seu inciso XXVI, que define Ponto de Entrega como o "ponto de conexão do sistema elétrico da concessionária com as instalações elétricas da unidade consumidora, caracterizandose como o limite da responsabilidade do fornecimento."

O artigo $3^{\circ}$ que trata do "pedido de fornecimento" estabelece que:

\footnotetext{
"Efetivado o pedido de fornecimento à concessionária, esta cientificará ao interessado quanto à:"

I - obrigatoriedade de:

(...)

b) instalação pelo interessado, quando exigido pela concessionária, em locais apropriados de livre e fácil acesso, de caixas, quadros, painéis ou cubículos destinados à instalação de medidores, transformadores de medição e outros aparelhos da concessionária, necessários à medição de consumos de energia elétrica e demandas de potência, quando houver, e à proteção
} 


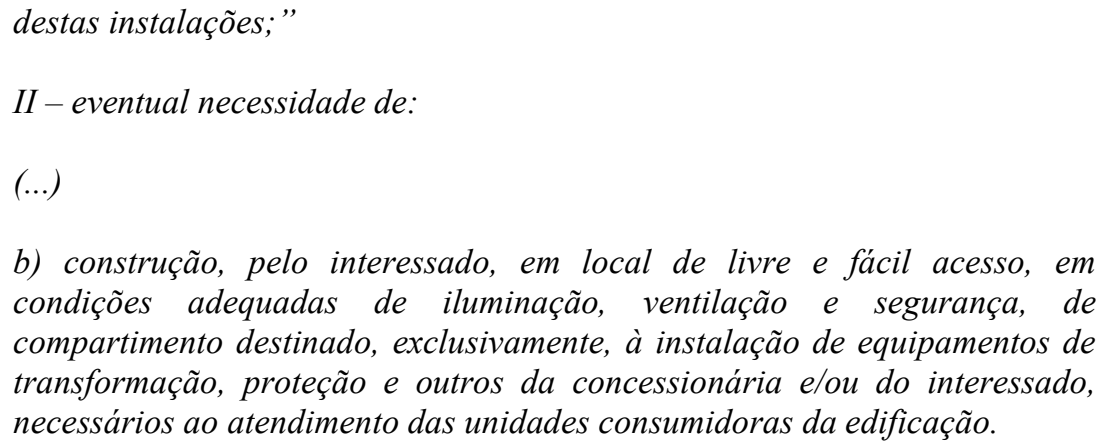

$\mathrm{O}$ artigo $9^{\circ}$, que trata do Ponto de Entrega, estabelece que o "ponto de entrega de energia elétrica deverá situar-se no limite da via pública com o imóvel em que se localizar a unidade consumidora(...)”

Pelo entendimento atual das concessionárias quanto à norma da Resolução $n^{\circ} 456 / 00$, todas as despesas decorrentes da conexão do consumidor, a partir do Ponto de Entrega são de responsabilidade do próprio consumidor.

No caso de moradias em área rural, essa responsabilidade pode chegar a valores muito elevados, ainda que a distância entre o Ponto de Entrega e o domicílio do consumidor seja de poucos metros. O custo, apenas do poste-padrão, gira em torno de, no mínimo, R\$ 450,00, ou seja, um valor próximo a um salário mínimo ou cerca de U\$ 250,00 .

De maneira geral, os autores e pesquisadores da eletrificação rural no Brasil aceitam a informação do Censo-IBGE 2000, que indica a renda familiar de cerca de $90 \%$ do universo de excluídos do acesso ao serviço público de distribuição de energia elétrica no meio rural na faixa de até três salários mínimos.

A renda familiar majoritária do perfil dos brasileiros atendidos pelo Programa Luz para Todos situa-se nessa faixa de renda. Conforme pesquisa quantitativa domiciliar de avaliação de satisfação e de impacto do Programa Luz para Todos, publicada pelo Ministério de Minas e Energia, em 7 de outubro de 2009, 60,4\% das famílias beneficiadas pelo Programa possuem renda familiar de até um salário mínimo - R \$465,00, em janeiro de 2010. 
A partir desses dados pode-se asseverar que a responsabilidade pelo custo do poste-padrão já seria elevada para essa população; acresça-se a esse o custo da fiação, conexões, disjuntores, quadro interno, escavação, colocação, mão de obra de eletricista etc. e ter-se-á um valor proibitivo para o trabalhador rural, que vive da agricultura familiar, conforme o próprio Ministério constatou.

O Manual de Operacionalização do Programa Luz para Todos estabeleceu outros critérios e obrigações, suspendendo a aplicabilidade da Resolução $n^{0}$ 456/00, de modo a viabilizar o atendimento mais abrangente possível. CAMARGO; RIBEIRO, (2009), ressaltam no Manual de Operacionalização, entre outros avanços, a inclusão do termo "ramal de conexão", inexistente na Resolução no 456/00. Esse termo, segundo os autores, decorre da obrigação de a concessionária levar a ligação até o interior do domicílio do consumidor e não somente até o limite da propriedade. Isto se confirma pela leitura da versão mais recente do Manual (versão 6.0).

Não é somente esse termo que se configura como uma inovação a favor do morador pobre da área rural e que decorre da obrigação de levar a ligação até o interior de sua residência. No item 7 - Critérios Técnicos de Atendimento, do Manual de Operacionalização do Programa Luz para Todos, Revisão 6, anexo à Portaria n ${ }^{0} 85$, de 22 de fevereiro de 2009 ao demonstrar as definições adotadas para fim dos critérios técnicos elenca, entre outros, os seguintes termos:

III - Ramal de Entrada: Condutores e seus acessórios compreendidos entre o ponto de entrega e o medidor;

IV - Ramal de Conexão: Condutores e seus acessórios compreendidos entre o medidor e a unidade consumidora;

$V$ - Circuito Interno Principal: Condutores e seus acessórios instalados dentro da unidade consumidora para alimentação das cargas (lâmpadas, tomadas etc). Estes condutores são partes integrantes do Kit de Instalação Interna;

VI - Circuito Interno Secundário: Condutores e seus acessórios instalados dentro da unidade consumidora para a ligação das cargas (lâmpadas, tomadas etc) ao circuito interno principal. Estes condutores são partes integrantes do Kit de Instalação Interna;

É de salientar que o Manual de Operacionalização, embora obrigue a concessionária ou permissionária a efetuar a ligação até o interior da residência, mantém 
o limite da sua responsabilidade pelo fornecimento no Ponto de Entrega, definido como: "Ponto de conexão do sistema elétrico da concessionária com as instalações elétricas da unidade consumidora", ou seja, nos mesmos moldes da Resolução nº 456/00.

O item 7.1.2 do Manual determina que:

As instalações do "Programa Luz para Todos" deverão atender aos
seguintes critérios:
(...)
IX - o padrão de entrada deverá incluir: ramal de ligação, poste auxiliar,
ramal de entrada caixa de medição, medidor, disjuntor de entrada,
aterramento, ramal de conexão, disjuntor do quadro de distribuição interna
do
domicílio etc. O disjuntor do quadro de distribuição interna deverá ser
instalado pelo Agente Executor, independentemente da obrigatoriedade de
instalação do kit interno no domicílio;

$X$ - em todas as residências com ligações monofásicas ou em residências em assentamentos rurais, comunidades remanescentes de quilombos ou territórios indígenas com ligações bifásicas, o Agente Executor deverá providenciar um kit de instalação interna que consiste no fornecimento e instalação de um ponto de luz por cômodo até o limite de três pontos de luz, duas tomadas, condutores, lâmpadas e demais materiais necessários.

O custo referente à instalação do kit poderá constar do orçamento do Programa de Obras a ser apresentado à ELETROBRÁS. O Agente Executor deverá apresentar a relação do(s) beneficiado(s) com esta instalação;

Observação: Os agentes executores, cujo padrão de engenharia prevê somente circuitos bifásicos para ligação dos domicílios, deverão instalar o kit mencionado acima.

Essa é uma diferença essencial e diz respeito, também, ao Ponto de Entrega. Nos termos da Resolução no 456/00 o Ponto de Entrega está localizado "no limite da via pública com o imóvel em que se localizar a unidade consumidora”. Em função disto, nos casos de propriedades em que o pai houvesse desmembrado suas terras para a construção de uma casa para o filho, este filho não teria direito a uma ligação. Do mesmo modo, no caso de uma fazenda, cuja casa sede já tivesse energia elétrica, as casas de colonos não teriam direito a uma ligação individual, ou como registrou FERNANDES JÚNIOR, (1999): “a casa grande é atendida e a senzala continua na escuridão" Esta é outra diferença significativa trazida pelo Programa Luz para Todos, ao invés de uma ligação por propriedade, a frase síntese seria: para cada domicílio um medidor. 
Um radialista perguntou ao Coordenador Estadual do Comitê Gestor de São Paulo se era verdade que o Programa estava usando dinheiro público para instalar, de graça, postes e cabos elétricos dentro de propriedade de fazendeiro rico. Era uma denúncia recebida contra o Programa. Respondeu o Coordenador: “- Sim. Em terra de fazendeiro rico mora gente pobre que tem direito à luz elétrica”. 


\section{0 - OS NÚMEROS DO PROGRAMA LUZ PARA TODOS NO ESTADO DE SÃO PAULO}

A meta inicialmente contratada para o Programa Luz para Todos, no Estado de São Paulo, era de, aproximadamente, 33.000 ligações. A realidade da eletrificação rural, contudo, fez com que esse número fosse superado em mais de $200 \%$. Serão discutidos alguns fatores que ajudam a entender essa situação, bem como servem para alertar que o projeto de governo que visa universalizar o atendimento de energia elétrica nas áreas rurais deve ser elevado ao nível de política de Estado, pois, como programa de governo, sempre manterá um "estoque de excluídos” a reclamar um novo programa e outro, e mais outro, indefinidamente.

O gestor e o governante ficarão sempre com um dilema político: assumir a existência desse estoque de excluídos e pensar em continuar o Programa - com o ônus de não ter conseguido concluir a tarefa a que se propôs e precisar se expor a uma prorrogação de prazo - ou assumir a conclusão do programa - com o ônus agora de deixar de atender e ter o caráter de atendimento universal frustrado. Ambas as possibilidades podem gerar custos políticos significativos.

A meta inicial do Programa Luz para Todos era atender dois milhões de novos consumidores até o final de 2008. Essa meta foi atingida no mês de maio de 2009. Começou em ritmo naturalmente muito mais lento do que o planejado. O Programa só deslanchou em 2006.

Os distribuidores ofereceram resistências silenciosas, já que haviam manifestado publicamente a aceitação, por ocasião da discussão do Projeto que resultou na Lei $n^{\circ} 10.438 / 02$.

Uma das tentativas de inviabilizar o Programa foi a proposição de projetos de preço muito alto (BETIOL, 2005)

O Programa demorou para alcançar credibilidade. As operações em São Paulo eram observadas por todas as concessionárias. No final do primeiro semestre de 2004, a CPFL resolveu aderir ao Programa e iniciou suas obras em junho, com um 
contrato de 4.000 ligações para a CPFL-Paulista e um de 1.500 para a CPFLPiratininga, ambos com duração de um ano.

Foi a chave que fez com que outras empresas aderissem. A ELEKTRO só conseguiu iniciar em novembro de 2004, exatamente um ano após o lançamento do Programa.

Mesmo assim, era previsível que não se conseguiria atender a todas as demandas, embora superasse metas em muitos Estados, como em São Paulo. Havia um ordenamento de governo que o Programa deveria ser concluído no prazo determinado e não cabia a seus operadores tomar outras iniciativas. A redação do decreto que autorizou a prorrogação do Programa não estabeleceu em que Estados isso se daria, atribuindo ao Ministério de Minas e Energia definir em quais Estados e para quais concessionárias se autorizaria prorrogar o Programa.

A literatura especializada em eletrificação rural, em todo o mundo, sempre aponta que é muito difícil a previsão do mercado por atender. O modelo BNDES/USP previa o apoio da extensão rural e de universidades para identificar quem precisava de atendimento. O Programa Luz da Terra teve, em sua primeira fase, resultado de apenas $2 \%$ das ligações previstas (PAZZINI, 1998) e se propôs a criação de comitês locais, chamados Serviço Municipal de Eletrificação Rural - SMER (PELEGRINI, 1998). Então, o programa deslanchou, mas ficou avaliado que foi justo nos Municípios que as audiências públicas dos SMERs eram mais concorridas, e o comitê local mais atuante, que os resultados numéricos eram mais significativos (PAZZINI, 2001). Foi, inclusive, avaliado que dentro das mesmas concessionárias ocorriam resultados bem diferentes entre uma agência regional e outra (KURAHASSI, 2001), sempre correlacionados com os níveis de atuação dos agentes que conduziam os SMERs, que eram fomentados, montados e acompanhados pela equipe de pesquisadores da USP, depois de um trabalho de consultores especializados. É oportuno lembrar que foi a importância da atuação desses pesquisadores que iam a campo, com recursos de um projeto de pesquisa que previa essa atividade, que deu origem à ideia de introduzir os Agentes Luz para Todos. (CARMO, 2005).

CARMO, (2005), relata uma experiência realizada como operador de três 
diferentes programas de eletrificação rural em uma das concessionárias que anteriormente eram privadas no Estado de São Paulo, a Companhia Santa Cruz, que atua em uma região de minifúndios e assentamentos que se misturam com latifúndios de cana de açúcar. Sucessivamente, as previsões eram superadas. Então, apoiou-se nos modelos teóricos que previam contato com as comunidades, com as lideranças, com os vereadores, com os prefeitos, padres e outros. A partir dos SMERs, organizaram-se assembléias, chamou-se a imprensa, vieram os prefeitos. Na sequência de sucessivas tranches, que perpassaram pelos diferentes programas, a demanda remanescente sempre surpreendia com um valor igual ou maior que a encontrada no planejamento da fase anterior. (CARMO, 2005).

Os outros teóricos ensinaram e CARMO, (2005), vivenciou na prática, que é temerário prever os números da eletrificação rural. Vários técnicos que passaram por essa experiência apontam um número que sempre aparece: um projeto previsto para atender cem, acaba por atender cento e cinquenta consumidores. (RIBEIRO, 2009). Os modelos utilizados pelos planejadores do Programa Luz para Todos não mostravam consistência em alguns pontos quando aplicados em São Paulo. A Secretaria de Energia do Estado de São Paulo auxiliou os planejadores a ajustar o modelo e chegou-se à conclusão de que haveria uma demanda de 60.000 ligações no Estado. As previsões da Secretaria faziam-na sugerir o número de 90.000, mas, ficaria oficialmente valendo o outro número. No entanto, dificuldades que surgiram nas fases de pré-discussão dos contratos acabaram por definir que a meta de São Paulo, pragmaticamente, seria o número supra mencionado de 33.000 a meta paulista, e isto ficou oficial, valendo em todas as instâncias (BETIOL, 2005) inclusive nesta dissertação.

Segundo (BETIOL, 2005):

...como há uma forte correlação entre o atendimento ao mercado rural e o surgimento de novas demandas, haverá certamente, que se presumir a manutenção do déficit a ser atendido no decorrer dos próximos anos. Isto quer dizer que, se alguém imaginar que construir 60 mil novas ligações poderá levar São Paulo à universalização, pode estar muito enganado. (BETIOL, 2005 p. 107)

No início de 2010 já se pode fazer uma projeção de que o Programa Luz para Todos vai acabar por atender entre 90.000 e 92.000 em São Paulo, quase o triplo 
da meta inicial.

Até o mês de maio de 2009, este era o quadro de atendimentos do estado de São Paulo:

\section{EVOLUÇÃO DAS LIGAÇÕES NO ESTADO DE SÃO PAULO}

$\begin{array}{llllll}2004 & 2005 & 2006 & 2007 & 2008 & 2009\end{array}$

\begin{tabular}{lllllll}
\hline 2.779 & 16.465 & 21.276 & 15.400 & 9.689 & 8.822 & 75.447
\end{tabular}

Fonte: Autor

10.1 - Alguns Municípios e seus números interessantes

A prática do Programa Luz para Todos demonstrou resultados consistentes com o histórico da eletrificação rural, no que tange às dificuldades de projetar o mercado. No Brasil, dos 2.000.000 iniciais já foram identificados cerca de 1.000.000 a mais. Em São Paulo, dos 60.000 que alguns vislumbravam, chegar-se-á a 90.000; em relação ao número oficial, isto é, a meta de 33.000 estabelecida em 2004, como já mencionado, por questões de facilidade administrativa, representa quase o triplo. Apenas em regiões onde a monocultura avassaladora da cana-de-açúcar avançou nos últimos anos houve queda de demanda prevista.

Há Municípios com resultados muito interessantes pelas surpresas constatadas. A primeira observação diz respeito ao Município de São José dos Campos, no Vale do Paraíba, revelando que a pobreza está ao lado dos bons índices de progresso econômico, que o atraso escuro ficar escondido junto do brilho desigual da agitada atividade econômica de base industrial. O sítio desse Município na Internet o apresenta da seguinte forma:

Com população de 632.491 habitantes(1), $21^{\circ}$ maior PIB do Brasil e $8^{\circ}$ do Estado de São Paulo em 2007(2), PIB per capita de R\$30,2 mil, São José dos Campos, a apenas $100 \mathrm{~km}$ da capital, é um dos centros industriais e de serviços mais importantes do Estado de São Paulo e do Brasil.

Terceira maior cidade exportadora do país, com US\$ 4,859 bilhões em 2009(3), ocupa a $9^{a}$ posição entre as melhores cidades do Estado de São Paulo e a $27^{a}$ entre os melhores Municipios do Brasil para se trabalhar, em pesquisa realizada pela Revista Você S/A em 2009 
$\begin{array}{lcccc}\text { Fonte: } & \text { estimativa } & \text { SEADE } & - & 2009 \\ \text { (2) Fonte: } & \text { Fundação } & \text { Seade/IBGE } & - & 2009 \\ \text { (3) Fonte: MDIC 2009” } & & & \end{array}$

Com todos esses números grandiosos, Município onde se desenvolve alta tecnologia, sede da Embraer, contando com a General Motors e a Petrobrás, entre outras grandes empresas, com características de alta urbanização e centro universitário dos mais conceituados, o Município de São José dos Campos teve, até maio de 2009, 1.836 ligações pelo Programa Luz para Todos. Nota-se, portanto, um imenso cinturão de pobreza rural no entorno da grande capital tecnológica do maior Estado da federação. Para registro, na fase inicial das operações, o Coordenador Estadual do Programa Luz para Todos foi chamado por lideranças comunitárias que diziam que lá havia uma demanda de 80 ligações; a concessionária, também de início, encontrou demanda de 200.

O Município de Mirante do Paranapanema, com perfil socioeconômico bem diferente e cognominado a capital da reforma agrária por abrigar cerca de 38 assentamentos da reforma agrária em seu território, teve até a mesma data aproximadamente 585 ligações, o que representa cerca de $3,5 \%$ da população total do Município.

Tomando como parâmetro o percentual da população atendida, há o exemplo de Sete Barras e Barra do Turvo, ambos Municípios extremamente pobres do Vale do Ribeira. O primeiro, com cerca de 13.000 habitantes, teve em torno de $6 \%$ de sua população atendida pelo Programa Luz para Todos. Já no Município de Barra do Turvo, que conta com aproximadamente 8.600 habitantes, com cerca de $60 \%$ vivendo na área rural, ao final do Programa terão sido ligados cerca de 1.300 domicílios, o que representa pouco mais de $15 \%$ da população total do Município e $25 \%$ da população que vive na área rural. Barra do Turvo foi a última das cidades do estado de São Paulo a receber a chegada da eletricidade em seu núcleo urbano.

Ubatuba, no Litoral Norte, teve $4 \%$ da população de 90.000 habitantes atendidos. Suas autoridades tinham pleno conhecimento de que muitas comunidades nas praias remotas e dentro da Mata Atlântica reclamavam por luz elétrica. Algumas comunidades, entendidas tradicionalmente como comunidades caiçaras, eram 
conhecidas apenas de pescadores e viajantes aventureiros, até a abertura da BR 101, a Rodovia Rio-Santos, em seu trecho entre Paraty-RJ e Ubatuba-SP, por volta de 1975. Só há pouco se declararam como remanescentes de quilombolas. Um fato que atesta o muito recente e repentino aparecimento da ideia de haver outros quilombos no Brasil além do Quilombo dos Palmares, em Alagoas - foi vivenciado pela equipe do Programa Luz para Todos. O Coordenador Estadual foi chamado para discutir no local a ligação da luz em alguns quilombos, que desconhecia existir, em abril de 2004. Alguns dias depois, recebeu um telefonema da Secretaria Especial de Políticas de Promoção da Igualdade Racial - SEPPIR, que tem status de ministério e foi criada nos mesmos dias de novembro do ano anterior que deram origem ao Programa Luz para Todos. Nessa ocasião foi questionado se já tinha conhecimento de que em São Paulo havia quilombos e respondeu que tinha visitado quatro, em Ubatuba. A funcionária da SEPPIR revelou que tinha em mãos uma lista dos doze quilombos conhecidos no estado de São Paulo e que não havia qualquer registro da existência de quilombo em Ubatuba. Então, o Programa Luz para Todos foi a alguns quilombos antes mesmo da SEPPIR, o que reforça a percepção de sua vocação de ferramenta de desenvolvimento social. Hoje a SEPPIR aponta a existência de mais de 35 comunidades quilombolas no estado de São Paulo. (RIBEIRO; YOSHINO; RIBEIRO, 2009)

Os quilombos de Ubatuba receberam a chegada da rede elétrica depois de vinte e cinco anos de luta. A equipe do Programa Luz para Todos abriu o processo de viabilização da extensão da rede elétrica aos quilombos do Cambury, no extremo Norte do Município e dentro do Parque Estadual da Serra do Mar, Núcleo Picinguaba, e Caçandoca, no extremo Sul do Município, na Semana Santa de 2004. O licenciamento ambiental foi aprovado no Natal de 2006. A obra da Caçandoca ficou pronta dois meses depois, mas a do Cambury, por atraso na autorização do órgão que administra a rodovia federal, só terminou bem depois, no Natal do ano seguinte, 2007. (RIBEIRO; YOSHINO; RIBEIRO, 2009)

Guaratinguetá, no Vale do Paraíba, com 120.000 habitantes, também teve o Programa Luz para Todos atingindo 4\% de sua população. Ao contrário do ocorrido em Ubatuba, as autoridades locais não faziam a menor ideia de que poderia existir tanta gente sem uma fonte regular de energia elétrica. Tampouco as associações, sindicatos e a própria imprensa. $\mathrm{O}$ atual prefeito de Guaratinguetá é engenheiro eletricista e fez parte 
do conjunto de pesquisadores da Politécnica. Uma conclusão de seu trabalho foi tomada como base para os estudos relatados nesta dissertação, e foi também levada aos planejadores do Programa Luz para Todos para consideração. É a constatação de que o setor elétrico liga luz na casa grande e deixa a senzala no escuro. (FERNANDES Jr., 1999). Afinal, nem o prefeito-pesquisador imaginava que seu Município era tão carente do atendimento do Programa Luz para Todos.

Um ponto que incomoda a alguns estudiosos da eletrificação rural é o fato de que o Município de Guaratinguetá vem apresentando resultados tão expressivos de ligações pelo Programa Luz para Todos e os Municípios de seu entorno, com áreas rurais de mesmo perfil socioeconômico, não apresentam demandas. Não é impossível que tais demandas ainda venham a acontecer, talvez depois de encerrado o programa atual.

10.2 - Discrepância de números

São muitas e diferentes as causas do aumento inesperado da demanda, em relação à inicialmente planejada. Alguns casos pontuais são relatados a seguir.

O agente Luz para Todos, Shinji Yoshino, que atua na região do Vale do Paraíba, Vale Histórico e Litoral Norte do Estado, relata fenômeno ocorrido na comunidade remanescente de quilombolas, Quilombo da Fazenda Picinguaba, localizada no Município de Ubatuba, no Km 12 da Rodovia Rio-Santos - BR 101, em plena Mata Atlântica, dentro do citado Parque Estadual da Serra do Mar, Núcleo Picinguaba. Essa comunidade recebeu ligações de energia elétrica no ano de 2007, quando foram atendidas 34 residências. Em virtude da chegada da energia elétrica, diversos quilombolas que de lá haviam saído para viver fora começaram a retornar. No início do ano de 2009, o número de residências ligadas havia saltado de 34 para 51, sendo que a direção do Parque responsável por aquela área de preservação, ainda estava avaliando outras 17 solicitações de outras famílias que pretendiam voltar ao seu local de origem.

No Vale do Ribeira, Município de Sete Barras, relata o Agente Luz para Todos Cláudio Roberto, que, a empresa agrícola de produção e exportação Bananas 
Magário, em uma de suas propriedades, a Fazenda Praia Alta, localizada no Bairro Votupoca, contava com trinta empregados que prestam serviço no cultivo da banana, com dezoito famílias residindo em dezoito casas de colonos. Com uma produção semanal de 2.500 caixas de banana nanica e 500 caixas de banana prata, entre as dezoito famílias, algumas tinham um atendimento precário de energia elétrica, emprestando energia de um mesmo medidor - que servia ao galpão - para três ou quatro casas mais próximas. As casas restantes não possuíam sequer esse arremedo de atendimento. No ano de 2.007, as dezoito casas foram efetivamente atendidas, recebendo cada uma seu medidor, beneficiando diretamente cerca de 80 pessoas que lá residem.

Durante vários anos, essas casas permaneceram na escuridão, havendo luz na casa-sede da fazenda e energia nos galpões. Somente com a chegada do Programa Luz para Todos essas casas de colonos puderam ser ligadas. Necessário esclarecer que, nos termos da Resolução $n^{0}$ 456/00, essa propriedade era considerada atendida pelo serviço de energia elétrica, ainda que cerca de 80 cidadãos brasileiros estivessem excluídos desse serviço.

Ainda no Vale do Ribeira, no ano de 2008, um fato totalmente atípico e imprevisto ocorreu. Naquela região, considerada uma das mais pobres do estado de São Paulo, diversas comunidades vivem, há décadas, em certos casos, séculos, em áreas que vieram a ser declaradas, por meio de leis estaduais como sendo de preservação permanente, até mesmo Parques Estaduais. Dos exemplos mais conhecidos menciona-se a Reserva de Juréia-Itatins e o Parque de Jacupiranga. Por estarem localizados em tais regiões, essas comunidades estavam impedidas de receberem a energia elétrica, na verdade a legislação determinava a saída da população dessas áreas.

Por meio da Lei Estadual $\mathrm{n}^{\circ}$ 12.810, de 20 de fevereiro de 2008, a configuração daquela área de preservação foi alterada, deixando de existir o Parque de Jacupiranga para dar lugar ao Mosaico de Jacupiranga.

Aquele que era considerado o maior parque de preservação do estado de São Paulo, criado no ano de 1.969, envolvendo parte de seis Municípios - Eldorado Paulista, Iporanga, Barra do Turvo, Cajati, Jacupiranga e Cananéia - teve sua área aumentada para 243.885,15 hectares, dividido em três parques estaduais, cinco Reservas 
de Desenvolvimento Sustentável (RDS), quatro Áreas de Proteção Ambiental (APA), duas Reservas Extrativistas (RESEX) e duas Reservas Particulares do Patrimônio Nacional (RPPN).

Fruto imediato dessa alteração, no âmbito do Programa Luz para Todos foi o surgimento de cerca de 1.200 novas demandas. Famílias que antes estavam impedidas de ser atendidas porque residiam em área de parque estadual, agora, em virtude da nova configuração do território, passaram a ter o direito de receber a energia elétrica e outros serviços públicos. (CAMARGO; RIBEIRO;GUERRA, 2009)

10.3 - O que mostram as cidades e os números - critérios de exclusão

Qualquer programa de atendimento em eletrificação que estabeleça um limite de qualquer natureza para a inclusão de novos consumidores, traz em si um critério de exclusão.

Todo e qualquer programa de eletrificação rural está sujeito a limites para sua implantação. Há as restrições de natureza legal, tais como limitações ambientais, fundiárias etc., que impedem o pleno atendimento do universo excluído. Há outros, porém, que são intrínsecos a cada programa proposto.

Ao se pensar em programas que tenham como fundamento a aplicação de verbas orçamentárias de qualquer nível de governo, ter-se-á que o critério de exclusão está indicado pela verba destinada ao programa.

Programas que se fundamentam no acesso ao crédito bancário ou de qualquer natureza para o morador da área rural, a fim de viabilizar o custeio das obras de eletrificação, terão como critério de exclusão a capacidade de endividamento dos moradores a atender.

No caso do Programa Luz para Todos, são três os principais critérios de exclusão. O primeiro deles é o custo unitário da obra, estabelecido por meio do limite do impacto tarifário resultante. De forma prática, estabeleceu-se que a obra com custo unitário de valor igual ou superior a três vezes o valor médio das obras contratadas não 
precisará ser atendida no prazo do Programa Luz para Todos, podendo ter seu atendimento diferido sem qualquer punição à concessionária ou permissionária. Este critério afeta diretamente aqueles moradores em locais mais distantes da rede da distribuidora ou de mais difícil acesso.

Outro critério de exclusão é de natureza contratual, ou seja, uma vez encerrado o contrato entre o agente executor e a Eletrobras os novos solicitantes não terão acesso ao Programa e retornarão às condições existentes anteriormente a 11 de novembro de 2003. Submetidos ao que estabelece a Resolução no 456/00 da ANEEL, deverão arcar com as despesas decorrentes da ligação do limite de sua propriedade até o seu domicílio, o que, conforme já demonstrado neste trabalho, configura-se como critério de exclusão para mais de $60 \%$ do perfil de consumidores atendidos pelo Programa Luz para Todos.

Por fim, este Programa apresenta um critério que se pode chamar de temporal. O Programa tem data certa para ser finalizado, 31de dezembro de $/ 2010$. Atingida esta data, o serviço público de distribuição de energia elétrica, no que diz respeito aos atendimentos às áreas rurais, retorna à condição anterior a 11 de novembro de 2003, ou seja, o atendimento fica limitado às propriedades rurais e não às moradias, o atendimento se dará até o limite da propriedade e não até o interior da moradia e os custos a partir do limite da propriedade voltam a ser de responsabilidade do solicitante. É o critério que este autor chama de critério do retrocesso histórico.

Nestes três critérios de exclusão estão incluídos, outros tais como dificuldade ou inexistência de acesso etc. Em vista da existência destes critérios de exclusão, e tendo ainda por base os casos de Municípios narrados anteriormente e a discrepância entre os números previstos e os resultados obtidos, pode-se afirmar que resultará, do final do Programa Luz para Todos, um contingente desconhecido que formará um estoque de excluídos de cujas proporções somente poderão ser conhecidas quando e se um novo programa for estabelecido.

Resulta dessa afirmação, fruto da constatação de que o universo a ser atendido é desconhecido e não passível de ser mensurado, que, como afirmado anteriormente: estabelecer meta de atendimento final para a eletrificação rural é o 
mesmo que estabelecer que nem todos serão atendidos, pois esse universo de excluídos vive em permanente expansão.

São diversos os fenômenos, além desses, que podem ser citados para entender ou explicar a discrepância entre os números de ligações previstos e as ligações de fato efetuadas.

Um importante fator a ser considerado é o número de assentamentos de trabalhadores rurais implantados no Estado. Embora com atuações diferenciadas, em São Paulo há dois órgãos responsáveis pela implantação e acompanhamento de assentamentos, o Instituto Nacional de Colonização e Reforma Agrária - INCRA federal, vinculado ao Ministério do Desenvolvimento Agrário e o Instituto de Terras do Estado de São Paulo - ITESP - estadual, vinculado à Secretaria da Justiça e Defesa da Cidadania do Estado de São Paulo. Durante os anos do Programa Luz para Todos houve um incremento no número de assentamentos a reclamar os serviços públicos essenciais. Essa demanda por energia elétrica oriunda de novos assentamentos rurais não estava prevista nos números das metas iniciais do Programa.

A própria existência doPrograma Luz para Todos ajudou o INCRA a incrementar os investimentos nos assentamentos. De acordo com informação no sítio do INCRA, em nível nacional, 130 mil famílias assentadas da reforma agrária foram atendidas peloPrograma Luz para Todos, com isso o INCRA economizou R\$ 160 milhões, podendo investir esse valor economizado em outras obras de infraestrutura como estradas e abastecimento de água para as famílias assentadas.

Em São Paulo, em outubro de 2007, a técnica do INCRA, Claudine Gomes, encaminhou mensagem eletrônica a este pesquisador, nos seguintes termos:

\footnotetext{
Venho informar sobre a quantidade de poços que o INCRA perfurou antes e depois doPrograma para Todos. Até início de 2003 existiam 67 poços perfurados nos assentamentos gerenciados pelo INCRA.

No periodo de 2003 até out/2007 perfuramos 105 poços profundos, considero que o não direcionamento das verbas do INCRA para implantação de energia nos projetos de assentamento, conseguiu resgatar uma demanda enorme de infraestrutura básica que é a água nos assentamentos.
} 
Ainda existe uma demanda de 92 poços para perfuração nos assentamentos, mas a expectativa do órgão é conseguir perfurar mais 50 poços em 2008.

Grande parte dos recursos destinados a obras de infra estrutura no INCRA até 2003 eram gastos com eletrificação rural, hoje a realidade e as expectativas são outras.

Enfim, para tentar entender a discrepância entre os números estabelecidos como metas iniciais do Programa Luz para Todos e os números alcançados, ou a alcançar, até dezembro de 2010, há que considerar alguns aspectos, como segue:

1. O Censo-IBGE 2000, que serviu de base para o estabelecimento das metas do Programa Luz para Todos, não considerou como "sem atendimento de energia elétrica" os moradores da área rural que tivessem sua energia obtida a partir de geradores a diesel ou gasolina.

2. O Censo-IBGE 2000 também não considerou "sem atendimento de energia elétrica" quem possuía "luz emprestada".

3. O aumento da demanda em virtude de novos assentamentos, assim como o incremento para esses novos assentamentos, inclusive em função do próprioPrograma Luz para Todos. Esses novos assentamentos não existiam quando da pesquisa do CENSO-2000, bem como quando do estabelecimento das metas.

4. Propriedades já ligadas mas na qual havia moradores não atendidos - a casa grande iluminada e a senzala na escuridão.

5. O movimento de retorno ao meio rural verificado em diversos locais, em função da chegada da energia elétrica e com ela possibilidades de conforto e melhoria nas condições de vida e mesmo de produção.

6. Por fim, há que se considerar que é característico da eletrificação rural o aumento da demanda a partir do atendimento da demanda existente. 
10.4 - Do crescimento vegetativo

A diferença entre o número de ligações previsto e o efetivamente atendido, bem como das novas demandas que surgirão não pode ser simplesmente atribuído ao crescimento vegetativo.

O mundo ideal de um programa como o Luz para Todos, que busca a "universalização" do acesso, seria aquele em que, por meio do Programa, se atenderia a toda a demanda existente, efetivamente universalizando o serviço público de distribuição de energia elétrica e, a partir daí, tudo seria "crescimento vegetativo".

Não é assim que acontece. Crescimento vegetativo ou natural, do ponto de vista das Ciências Demográficas, é o percentual do aumento populacional decorrente da diferença entre nascimentos e falecimentos em uma determinada região, comunidade ou mesmo país. Do ponto de vista das concessionárias de distribuição de energia elétrica o crescimento vegetativo está relacionado com o crescimento do número de consumidores, sem qualquer interferência externa ao meio atendido.

Por esse critério, crescimento vegetativo é o aumento do mercado consumidor em determinada área, sem que haja qualquer fator externo, seja de que natureza for, a influenciar tal crescimento.

Não é crescimento vegetativo o retorno de pessoas ao meio rural incentivadas por políticas de valorização da atividade agrária, o estabelecimento de assentamentos de reforma agrária ou a chegada de novos moradores pela existência de algum atrativo social ou econômico antes inexistente.

Desse modo, a lógica do crescimento da demanda por energia elétrica no meio rural não está relacionada simplesmente ao crescimento vegetativo e sim à dinâmica da sociedade que pode ser ditada, inclusive, por políticas de desenvolvimento local, regional etc., por avanços nas conquistas fundiárias de movimentos organizados etc. Enfim, por fenômenos não previsíveis, como é o crescimento vegetativo.

O crescimento da demanda por eletrificação diante da existência de um 
programa de atendimento não é linear, está sujeito a variáveis imprevisíveis. (CAMARGO; RIBEIRO; GUERRA, 2009)

Em vista dos números da agricultura familiar dos últimos anos, dos resultados econômicos da agroindústria, deve se pensar se a demanda por energia elétrica não vai novamente surpreender aos que esperam pelo mero crescimento vegetativo. Com certeza, a expectativa de haver luz no meio rural, ela em si, já é um pólo de atração de novo mercado para a eletrificação rural (STRAZZI, 2009). 


\section{1 - DE 31 DE DEZEMBRO DE 2010 A 10 DE NOVEMBRO DE 2003}

MARQUES, (2005), tratando da situação de moradores da área rural que não poderiam ser atendidos pelo Programa Luz para Todos, por uma questão específica e relativa ao seu campo de estudo, pergunta: "o que vai acontecer se não acontecer nada?"

Pergunta semelhante é o que se tenta responder neste trabalho: o que irá acontecer a partir do dia 31 de dezembro de 2010, quando oficialmente se encerra o Programa Luz para Todos e volta a viger, juntamente com a Lei da Universalização, os dispositivos da Resolução $n^{\circ}$ 456/00 da ANEEL que não favorecem a inclusão de todos os que vierem a necessitar da ligação de energia?

Ao término do Programa Luz para Todos, com o atendimento das metas estabelecidas pela Resolução Normativa n ${ }^{0}$ 365, de 19 de maio de 2009, se considerará que o serviço público de distribuição de energia elétrica estará universalizado no país. Uma parcela da sociedade brasileira, majoritariamente composta por pobres residentes em área rural, de difícil acesso, com baixíssima renda, não concordará com essa afirmação.

O final do Programa Luz para Todos e da aplicação das normas hoje em vigência a partir do Manual de Operacionalização, trará de volta as condições estabelecidas pela Resolução n ${ }^{\circ}$ 456/00.

No ano de 2009, a ANEEL colocou em revisão essa Resolução, entretanto não houve qualquer alteração em relação à definição de Ponto de Entrega ou da responsabilidade da concessionária ou permissionária em levar o atendimento para além limite da propriedade.

Isso significa, na prática, que, a partir de $1^{\circ}$ de janeiro de 2011 os novos assentados da reforma agrária, os filhos de trabalhadores rurais que construírem suas casas para iniciar sua vida, enfim, que todos aqueles que demandarem por energia elétrica no meio rural terão que arcar com despesas fora do alcance de suas rendas familiares. 
Uma amostra de como será a rotina dos demandantes por energia elétrica no país universalizado e sob a regência da Resolução 456/00 foi apresentada pelo Gerente de Infraestrutura e Meio Ambiente do ITESP - Instituto de Terras do Estado, senhor Laércio Lico Júnior, por meio de correspondência eletrônica enviada a este pesquisador, no dia 28 de outubro de 2009, após haver relatado o problema em reunião ocorrida anteriormente.

No âmbito do Programa Luz para Todos, os equipamentos comunitários, como poço de abastecimento de água, desde que não particulares, são ligados nas mesmas condições que as residências, sem qualquer custo para o solicitante.

A área de concessão da concessionária Caiuá, pertencente ao Grupo Rede, já foi considerada universalizada, pois atingiu a meta estabelecida. Apesar disso, surgem novas demandas, no caso narrado pelo Gerente do ITESP, três poços comunitários, perfurados em três diferentes assentamentos - Assentamento Maturi, Município de Caiuá, Assentamento São José da Lagoa, no Município de Piquerobi e Assentamento Chico Castro Alves, no Município de Martinópolis, todos na região do Pontal do Paranapanema.

Solicitada a ligação à concessionária local, essa recusou-se a efetuar a ligação, nos termos da Resolução $\mathrm{n}^{\circ}$ 456/00, por se tratar de segunda ligação em propriedade já atendida. Questionada no sentido de se tratar de equipamento comunitário, teve a resposta de que a Resolução não previa essa segunda ligação, sem custo, ainda que até a divisa da propriedade.

Outra terrível circunstância presenciada por este pesquisador ocorreu durante uma reunião em uma concessionária que, ao referir-se a ligação em uma comunidade de difícil acesso ouviu do representante da mesma que, no caso daquela comunidade iria "empurrar com a barriga" e jogar para após o término do Programa. Afinal, sob a égide da Resolução $n^{0}$ 456/00, não teria que atender, uma vez que a comunidade não teria como arcar com as despesas decorrentes.

Foi dito anteriormente neste trabalho que o direito à energia elétrica, aí 
incluído o acesso e o uso, se configura como direito essencial, relacionado com o Direito de Consumidor e, ao mesmo tempo, Direito Ambiental. Enquanto Direito Ambiental tutelado pela Constituição Federal, o direito ao acesso ao serviço público de distribuição de energia elétrica deve ser garantido para as presentes e as futuras gerações.

Retornar às regras excludentes da Resolução $n^{0} 456 / 00$ significa abandonar as presentes e futuras gerações, negando-lhes o direito que hoje existe, admitindo-se um retrocesso normativo que beneficia a distribuidora, mas, exclui do atendimento os casos apontados. 


\section{2 - ASPECTOS QUE INDICAM UM DESEJO DE PERMANÊNCIA DAS CONDIÇÕES ESTABELECIDAS PELO PROGRAMA LUZ PARA TODOS}

As condições que propiciaram a proposição, criação e execução de um programa de eletrificação rural, nos moldes do Programa Luz para Todos, são resultado de um pacto da sociedade brasileira para "construir uma sociedade livre, justa e solidária; garantir o desenvolvimento nacional; erradicar a pobreza e a marginalização e reduzir as desigualdades sociais e regionais; promover o bem de todos, sem preconceitos de origem, raça, sexo, cor, idade e quaisquer outras formas de discriminação."

Esse pacto foi consagrado no dia 5 de outubro de 1988 e estabelecido na condição de fundamentos da República Federativa do Brasil, no artigo terceiro da Constituição Federal.

Consequências desse pacto são: a criação de um sistema de seguridade social, o estabelecimento de políticas de afirmação - como o reconhecimento dos direitos das comunidades remanescentes de quilombo - entre outros.

Como construir uma sociedade livre, justa e solidária, garantir o desenvolvimento nacional, erradicar a pobreza e a marginalização e reduzir as desigualdades sociais e regionais, promover o bem de todos, sem preconceitos de origem, raça, sexo, cor, idade e quaisquer outras formas de discriminação se não forem dadas a todos os mesmos direitos e condições? Pior ainda, como garantir os fundamentos da República caso seja retirado dos brasileiros pobres do meio rural de nosso país um direito já concedido a outros. O que acontecerá se as futuras gerações forem alijadas de direitos que significaram transformações das condições de vida de mais de 11.500 .000 brasileiros?

O país deseja a permanência dessas condições de amplo acesso ao serviço público de distribuição de energia elétrica. Isso pode ser verificado por vários sinais. 
O primeiro sinal desta vontade de permanência dos critérios do Programa Luz para Todos pode ser encontrada no próprio Manual de Operacionalização, no item 5.7.1, inciso XIX, da sua versão mais recente, Revisão 6, consta:

\begin{abstract}
O Agente Executor que, na revisão da Resolução 175, não tiver apresentado previsão de novas metas para os anos de 2009 e 2010, considerando a possibilidade de novas demandas decorrentes do crescimento vegetativo no meio rural, poderá, até o encerramento doPrograma Luz para Todos, complementarmente aos procedimentos estabelecidos pela Resolução 456 ANEEL, instalar o ramal de conexão, padrão de entrada e kit de instalação interna, desde que atendidas às condições abaixo:

a) Celebração de Termo de Compromisso especifico entre os Agentes Executores e o Ministério de Minas e Energia, com a interveniência da ELETROBRÁS, no qual estarão definidas as expectativas das metas deste tipo de atendimento, com base no seu crescimento vegetativo no meio rural;

b) Para o atendimento aos consumidores definidos no Termo de Compromisso referido no item " a", a ELETROBRÁS celebrará contrato de subvenção, com os Agentes Executores, seguindo seus procedimentos normais de análise e contratação do Programa LPT, exceto a forma de liberação de recurso que se dará na modalidade de reembolso, observando ainda as seguintes condições:

b.1) Cobertura exclusiva dos custos diretos de implantação do padrão de entrada sem o medidor, do kit de instalação interna e do ramal de conexão, o qual deverá possuir distância máxima de $250 \mathrm{~m}$ até o domicílio a ser atendido;
\end{abstract}

Essa possibilidade de manter critérios de ligação similares aoPrograma Luz para Todos, mesmo para aqueles agentes concessionários ou permissionários que já tivessem suas áreas consideradas universalizadas demonstra o desejo do Estado brasileiro em estender ao máximo os efeitos desse programa.

No dia 20 de janeiro de 2010, o Presidente da República sancionou, com vetos, a Lei da Tarifa Social de Energia Elétrica. A Lei estabelece critérios e percentuais de desconto para consumidores de baixa renda.

A Lei em questão estava em discussão desde o ano de 1.999, a partir do Projeto de Lei $\mathrm{n}^{\mathrm{0}} 1.921 / 1999$. Essa Lei procura garantir uma parte significativa do que seria o conceito de serviço adequado, o direito ao uso contínuo. Ou seja, a continuidade do serviço, pelo estabelecimento de faixas de desconto relacionados a faixas de renda, participação em programas sociais de complementação de renda etc.

A parte da Lei que tratava do amplo acesso ao serviço público de 
distribuição de energia elétrica, consubstanciados nos artigos 13 e 14 do Projeto de Lei citado, traria a possibilidade de atendimento, ao consumidor baixa renda e outros albergados pela Lei, como segue:

Art. 13. Os custos de instalação dos padrões de entrada de novos consumidores beneficiados pela Tarifa Social correrão por conta das concessionárias e permissionárias de distribuição de energia elétrica.

Art. 14. As concessionárias e permissionárias de distribuição de energia elétrica deverão responsabilizar-se pelos custos de aquisição e instalação dos equipamentos, associados ao processo de medição e faturamento da energia vendida aos consumidores que, atendidos em baixa tensão, exerçam atividades de irrigação e de aquicultura, desde que estejam enquadrados na classificação de agricultura familiar, nos termos da Lei no 11.326, de 24 de julho de 2006.

Em parecer apresentado por comissão especial da Câmara Federal destinada a analisar o Projeto de Lei $\mathrm{n}^{\circ} 1.921$ de 1999 os artigos 13 e 14 foram suprimidos, em virtude de argumentos apresentados pela ANEEL, como consta do referido parecer, exarado aos 13 de outubro de 2009:

Concordamos, também, com a supressão do art. 13 do Substitutivo aprovado inicialmente na Câmara dos Deputados, dado que a ANEEL argumentou que os custos da instalação de medidores por conta das concessionárias de distribuição de energia elétrica levaria a uma quebra do equilíbrio econômico-financeiro dos contratos, demandando significativa elevação de tarifas.

Pelas mesmas razões do item anterior, também concordamos com a supressão do art. 14 da proposição aprovada inicialmente na Câmara dos Deputados.

Faltou ao legislador a sensibilidade para entender que a exclusão desses dois artigos mantém uma situação inaceitável de exclusão e, principalmente, faltou considerar que não se estava propondo uma alteração a todos os consumidores brasileiros e sim àqueles classificados na condição de baixa renda, nos termos da Lei proposta.

Não é mensurável, a priori, o impacto tarifário da manutenção de tais artigos, pois ainda não se têm os números de exclusão após o final do Programa Luz para Todos. Ainda assim, a questão não deve ser a de se manter a exclusão para garantir o equilíbrio econômico-financeiro e sim buscar formas de se garantir o equilíbrio econômico-financeiro viabilizando o atendimento dos cidadãos mais pobres do país. Foi 
esta vontade política que levou a uma engenharia financeira que possibilitou o atendimento pelo Programa Luz para Todos, na qual fundos setoriais, subvencionados e financiados, recursos estaduais e contrapartida das concessionárias foram mesclados em percentuais que garantissem a modicidade tarifária e o equilíbrio econômico-financeiro.

A própria Lei $n^{0} 12.212 / 2010$, no artigo 11, que altera a Lei $n^{0} 9.991$, de 24 de julho de 2000, ao alterar o inciso V daquela Lei, indica uma das fontes de recursos para aplicação em baixa renda, ou seja, no mínimo $60 \%$ dos recursos de programas de eficiência energética.

Deste modo, permanece ainda sem garantia de atendimento do serviço público de energia elétrica o morador pobre do meio rural brasileiro, apesar da vontade demonstrada em incluí-lo, quando da discussão da Lei no 12.212, de 20 de janeiro de 2010 .

Se há desejo de permanecer o atendimento amplo de cada um e de todos os moradores das áreas rurais brasileiras, por que esse atendimento não permanecerá em vigência?

Esta é uma pergunta inquietante. Se toda a sociedade brasileira concorda com o direito de cada família brasileira, sem distinção de qualquer espécie, receber o serviço de energia elétrica, se o Estado brasileiro entende que esse é um direito que se deve manter, se os princípios constitucionais e infraconstitucionais garantem esse direito, por que ele não se efetiva?

Mais ainda, se houve, por cerca de sete anos, uma experiência bem sucedida de atendimento amplo a todos os moradores do meio rural brasileiro, por que a partir de 1 de janeiro de 2011 voltar-se-á às condições do passado, que são excludentes?

Esta dissertação assume a tradição universitária de formular recomendações, quando julga de interesse da sociedade, e entende que deve fazer o registro daquilo que entende ser uma contribuição que emana do trabalho de pesquisa, realizado na forma de uma proposta acadêmica. 
A proposta que se coloca diante das questões discutidas é a transformação do Programa Luz para Todos, um programa de governo, em uma política de estado, estabelecida na estrutura regulatória do sistema elétrico brasileiro. Para tanto faz-se necessária a revisão da regulação atual, de maneira a adequá-la à legislação e à Constituição Federal, tornando-a fator de inclusão social e não o contrário. 


\section{3 - UNIVERSALIZAÇÃO DO ACESSO E USO DA ENERGIA ELÉTRICA}

FUGIMOTO, (2005), ao propor uma conceituação do que seja "universalizar" afirma que "corresponde ao ato de generalizar o serviço de energia elétrica, independentemente da classe de consumidor" (FUGIMOTO, 2005 p.07)

O autor vincula o conceito de universalização do de "serviço adequado" estabelecido como obrigação de concessionários e permissionários de serviço público no artigo 175, inciso IV, da Constituição Federal.

No entendimento deste pesquisador, sendo o serviço de distribuição de energia elétrica um serviço público, de natureza essencial, o seu acesso deve ser garantido a todos os brasileiros sem qualquer espécie de distinção ou barreira.

Assim, universalização é a garantia de atendimento nas mesmas condições de tempo e exigências formais para qualquer solicitante, em qualquer classe ou localização geográfica, sendo admitidos, tão somente, prazos diferenciados para casos diferenciados, como aqueles que dependam de licenciamento ambiental ou outras autorizações especiais, com prazos próprios.

13.1 - Direito ao acesso não é o mesmo que universalização do atendimento

É possível se garantir a universalização do serviço sem se garantir o direito de acesso ao serviço público de distribuição de energia elétrica.

Embora aparentemente contraditória, a frase acima é de fácil compreensão.

A universalização do acesso, nos termos das resoluções $n^{0} 223 / 03$ e $n^{0}$ 456/00, com sua definição de Ponto de Entrega que leva à leitura equivocada de que o limite da responsabilidade da concessionária pelo fornecimento é o mesmo que o limite da responsabilidade da concessionária pela ampliação de sua rede de clientes, limita em muito a possibilidade de o pobre da área rural vir a ser atendido.. 
A leitura que se faz da Resolução $n^{\circ} 456 / 00$ é equivocada e tendenciosa. Toda a legislação que fundamenta o setor elétrico brasileiro, conforme já comprovado em diversos pontos deste trabalho, abomina a participação financeira do consumidor/solicitante do serviço público de energia elétrica. A única responsabilidade financeira do consumidor é o pagamento da tarifa, único valor que pode ser dele cobrado pela concessionária ou permissionária do serviço público de distribuição de energia elétrica.

Esta leitura equivocada e tendenciosa põe na larga faixa da exclusão do acesso um contingente de brasileiros do meio rural que sequer serão quantificados. Assim, garantir critérios de universalização que promovam qualquer nível de exclusão é confirmar o paradoxo de que universalizar o acesso e garantir o direito ao acesso do serviço público de distribuição de energia elétrica são coisas totalmente diferentes entre si.

O Poder Concedente não pode ignorar essa situação paradoxal, seria permitir que as concessionárias possam voltar a falar "ligamos todos na forma da lei" para escamotear a exclusão real.

13.2 - Da ilegalidade e inconstitucionalidade da participação financeira do consumidor de energia elétrica nos custos de conexão ao sistema

Ainda que a Resolução no 456/00, na letra "e" do inciso II, do artigo $3^{\circ}$ estabeleça que a concessionária deve informar acerca da eventual necessidade de "participação financeira do interessado, na forma da legislação e regulamentos aplicáveis”, nossa legislação não admite tal participação financeira, nas ligações domiciliares até $50 \mathrm{KV}$. Como já exaustivamente exposto neste trabalho, sendo este inciso total e completamente ilegal além de inconstitucional, pois que a única obrigação do consumidor de energia elétrica é o pagamento da tarifa devida.

Apenas para reafirmar, pois já se tratou deste tema anteriormente, resume-se aqui o principal fundamento constitucional que impede a cobrança de participação financeira do consumidor do serviço público de distribuição de energia elétrica. 
O artigo 175 da Constituição Federal, que trata do regime de concessão e permissão dos serviços públicos, entre os quais o de distribuição de energia elétrica, estabelece que tais serviços são de responsabilidade do Poder Público, que poderá fazêlo diretamente ou por meio do regime de concessão ou permissão e destina a regulamentação por Lei infraconstitucional o estabelecimento da política tarifária.

A Lei, no caso, foi a de $\mathrm{n}^{\circ} 8.987$, de 13 de fevereiro de 1995 . O inciso I do artigo estabelece o recebimento do serviço adequado pelo usuário, sem prejuízo da aplicação da Lei n ${ }^{\circ}$ 8.078/90 - Código de Defesa do Consumidor.

Nos artigos $9^{\circ}$ a $13^{\circ}$ a Lei em comento regulamenta a política tarifária. Em nenhum ponto dessa Lei se estabelece ou se autoriza que seja cobrada qualquer participação financeira do consumidor do serviço público de distribuição de energia elétrica, para ser conectado ao sistema elétrico.

O parágrafo único do artigo 11 admite a possibilidade de fontes ou receitas alternativas com o fito de favorecer a modicidade tarifária.

No artigo 23, que trata das cláusulas essenciais do contrato de concessão está estabelecido no inciso $\mathrm{V}$, como cláusulas essenciais aquelas que digam respeito:"aos direitos, garantias e obrigações do poder concedente e da concessionária, inclusive os relacionados às previsiveis necessidades de futura alteração e expansão do serviço e consequente modernização, aperfeiçoamento e ampliação dos equipamentos e das instalações; "

Em outro ponto da lei encontra-se o inciso VI, que trata dos direitos e deveres do usuário para obtenção e utilização do serviço.

“A Lei não possui palavras inúteis”, assevera o brocardo jurídico tão caro aos juristas. Além de não abrigar palavras inúteis, a Lei se organiza de modo a se entender as intenções do legislador, muitas vezes não expressas em texto escrito.

Tal é o caso. Se o legislador separou os direitos e deveres do usuário para 
obtenção e utilização do serviço dos direitos, garantias e obrigações do Poder Concedente e da Concessionária, inclusive os relacionados às necessidades de expansão do serviço, modernização, aperfeiçoamento e ampliação dos equipamentos e das instalações, sua intenção cristalina é de afastar do usuário qualquer responsabilidade que seja do Poder Concedente e do Agente Concessionário ou Permissionário.

Após a reestruturação do setor elétrico brasileiro, com sua transferência em grande parte a investidores privados, as únicas previsões de participação financeira de parte do usuário são na forma de investimento, como participação no capital da empresa, ou como adiantamento da universalização, garantido o ressarcimento. Tendo em vista que o Programa Luz para Todos antecipou as metas de universalização, nem mesmo essa antecipação será devida, posto que não haverá mais o que antecipar.

A Resolução $n^{0}$ 223/2003 é bem mais expressa quanto à proibição de participação financeira por parte do usuário do serviço público de distribuição de energia elétrica.

Seus artigos $3^{\circ}$ e $4^{\circ}$ afirmam a gratuidade do acesso, conforme se vê:

Art. $3^{\circ}$ A partir da data de publicação desta Resolução, a concessionária deverá atender, sem qualquer ônus para o solicitante, ao pedido de nova ligação para unidade consumidora cuja carga instalada seja menor ou igual a $50 \mathrm{~kW}$, com enquadramento no Grupo B, que possa ser efetivada mediante extensão de rede em tensão inferior a 2,3 $\mathrm{kV}$, inclusive instalação ou substituição de transformador, ainda que seja necessário realizar reforço ou melhoramento na rede em tensão igual ou inferior a $138 \mathrm{kV}$.

Art. $4^{\circ}$ A partir de 10 de janeiro de 2004, a concessionária também deverá atender, sem qualquer onus para o solicitante, ao pedido de nova ligação para unidade consumidora cuja carga instalada seja menor ou igual a 50 $\mathrm{kW}$, com enquadramento no Grupo B, que possa ser efetivada em tensão inferior a 2,3 kV, ainda que seja necessária extensão de rede em tensão igual ou inferior a $138 \mathrm{kV}$, observado o respectivo Plano de Universalização de Energia Elétrica. 


\section{4 - PROBLEMAS, CONCLUSÕES E PROPOSTA DESTE TRABALHO}

Chegando ao final deste trabalho algumas conclusões se colocam necessárias e, em seguida a essas conclusões, propostas acadêmicas são apresentadas como uma forma de evitar os problemas que se evidenciam como possíveis.

A conclusão básica é de que por meio dos critérios utilizados pelo Programa Luz para Todos pode-se garantir o acesso ao serviço público de distribuição de energia elétrica a todos e a cada brasileiro que vive no meio rural, independentemente de sua condição social ou localização geográfica.

Essa possibilidade de atendimento amplo e universal atende aos preceitos de cidadania e dignidade da pessoa humana, do artigo $1^{\circ}$ e aqueles elencados no artigo $3^{\circ}$ da Constituição Federal, bem como ao conceito de serviço adequado reclamado pelo artigo 175 da mesma Carta Cidadã e confirmado pela legislação infraconstitucional.

Decorrente dessa primeira conclusão é a de que é possível garantir esse atendimento a futuras gerações e a todos os que hoje ainda se encontram excluídos do sistema elétrico brasileiro, por que esse é um desejo da sociedade brasileira transformado em mandamento legal.

Outra conclusão é que ao deixar de vigerem as normas relativas ao Programa Luz para Todos e retornando os moradores das áreas rurais ao programa de universalização dentro da submissão aos ditames da Resolução 456/00, será criado um imenso "estoque de excluídos" para futuros "programas de eletrificação rural", a depender do maior ou menor alcance social dos eventuais governantes.

Por fim, a proposta que se apresenta é a alteração da Resolução $n^{\circ}$ 456/00, separando o limite da responsabilidade pelo fornecimento da energia elétrica, limitada ao Ponto de Entrega, da responsabilidade pela conexão de novos usuários à rede, que é obrigação da concessionária ou permissionária e do Poder Concedente.

Prega-se aqui que se deve garantir a ligação gratuita, no mínimo, até o quadro de distribuição interna do domicílio do solicitante. 
Nos termos da legislação vigente, se tal atendimento levar a significativa alteração do equilíbrio econômico-financeiro ou em elevação imprevista e excessiva da tarifa, que seja o Poder Concedente chamado a cumprir com sua obrigação do inciso $\mathrm{V}$ do artigo 23 da Lei $n^{0} 8.987$ de 13 de fevereiro de 1995 para, juntamente com a concessionária ou permissionária, responsabilizar-se por esses custos, e não exigir do usuário a ser ligado qualquer participação financeira na obra de ligação.

De que modo essas medidas serão implementadas, qual arranjo financeiro será proposto, se serão criados fundos específicos ou se serão estabelecidas metas anuais de atendimento com compensações de ordem tributária ou outras formas de participação estatal, são discussões a serem levadas em conjunto com a sociedade com urgência. O que não se pode admitir é que a sociedade e o Estado brasileiro, após inovarem mundialmente no modo de levar o serviço público de distribuição de energia elétrica a todos os que dele necessitam, após verificarem a funcionalidade desse modo funciona, simplesmente abram mão de todo esse avanço social e admitam uma volta a um passado de exclusão e escuridão dos brasileiros mais pobres das áreas rurais do país. 


\section{CONCLUSÃO}

O que restou comprovado ao final desta caminhada pelos vários momentos da eletrificação rural no Brasil e pela estrutura normativa da distribuição de energia elétrica é que não se precisa voltar às situações excludentes que reinaram até pouco tempo.

Ficou comprovado que a exigência de qualquer valor do consumidor, que não seja decorrente do seu consumo de energia elétrica, é vedada pela legislação que fundamenta o setor elétrico brasileiro, a começar pela Constituição Federal.

Quando se faz referência à expressão "legislação" está se remetendo à Constituição e leis infraconstitucionais, não em regulamentos e instruções normativas. Os preceitos constitucionais e infraconstitucionais são imperativos, portanto cogentes, ou seja, não estão sujeitos sequer a acordos de vontades ou à vontade individual. Quando há contradição entre a regra menor e a regra maior, é a regra menor que perde eficácia.

Muito tempo passou para se chegar a um desenho financeiro que viabilizasse o efetivo cumprimento da legislação, mas, os pobres do meio rural brasileiro não dispõem de advogados e capital para fazer valer seus direitos. Foi preciso um ato de vontade política para que a luz chegasse a determinados locais excluídos durante décadas das prioridades das empresas de distribuição.

Os números de atendimentos no Estado mais rico da Federação são de estarrecer. Atender a $15 \%$ da população total de uma cidade, porcentagem que jamais teriam acesso ao serviço de energia elétrica, deve ser um estímulo à manutenção dos mecanismos que possibilitaram essa inclusão.

Em 31 de dezembro de 2010 o Programa Luz para Todos chega ao seu termo. Nesta data, deverão ter sido ligados cerca de 3.000.000 de domicílios, beneficiando diretamente cerca de 15 milhões de brasileiros, $60 \%$ dos quais com renda inferior a um salário mínimo. Após essa data, quantos deixarão de ser atendidos? 
Para a proposta deste trabalho, pouco importa a resposta dada à questão retro, pois, tratando-se de muitos, em igual número à quantidade atendida, se justifica a transformação do Programa de Governo em Política de Estado; se forem poucos, número irrisório de pessoas, não se justificará deixar tão pouca gente na escuridão. Ainda assim, será uma maldade histórica.

Como conclusão deste trabalho, fica a reflexão de que o consumidor pobre da área rural não pode ficar excluído do serviço público de distribuição de energia elétrica. Deve, ao contrário, ser atendido com a mesma presteza com que se atende ao consumidor urbano, e deve ser atendido sem custo, sem que dele se exija qualquer participação financeira. Por que o sistema normativo nacional assim determina.

Os estudos e conclusões deste trabalho se aplicam igualmente tanto ao atendimento por extensão de redes convencionais quanto por outras fontes de geração de energia elétrica - como os sistemas fotovoltaicos, minirredes etc., tendo em vista que se não for garantido o atendimento a todas as moradias da zona rural, não fará qualquer diferença saber de que fonte a energia não será recebida.

Quanto à manutenção do equilíbrio econômico-financeiro, cabe ao agente concessionário e ao Poder Concedente buscar a melhor forma de mantê-lo, pois é de responsabilidade de ambos os custos pela ampliação da rede de consumidores. Ao consumidor cabe tão somente pagar a tarifa pelo consumo da energia elétrica, nada mais.

A estrutura utilizada pelo Programa Luz para Todos já provou que isso é possível, portanto, só voltaremos à idade das trevas da eletrificação rural por incompetência ou maldade. E já ficou claro que incompetentes não somos... 


\section{REFERÊNCIAS BIBLIOGRÁFICAS}

AGÊNCIA NACIONAL DE ENERGIA ELÉTRICA. Resolução 456, de 29 de novembro de 2.000

. Resolução 223, de 29 de abril de 2.003

Resolução Normativa 365, de 19 de maio de 2.009

BRASIL. Constituição Federal de 5 de outubro de 1.988

. Decreto Presidencial, 02 de dezembro de 1.999

. Decreto 41.019, de 26 de fevereiro de 1.957

. Decreto 1.033, de 22 de maio de 1.962

. Decreto 62.655, de 03 de maio de 1.968

. Decreto 23.501, de 27 de novembro de 1.933

. Decreto 4.873, de 11 de novembro de 2.003

. Lei 4.156 , de 28 de novembro de 1.962

. Lei 6.938 , de 31 de agosto de 1.981

. Lei 7.783, de 28 de junho de 1.989

. Lei 8.078, de 11 de setembro de 1990

. Lei 8.987 , de 13 de fevereiro de 1.995

. Lei 9.074 , de 7 de julho de 1.995 
BRASIL . Lei 9.427, de 26 de dezembro de 1.996

. Lei 9.991 , de 24 de julho de 2.000

. Lei 10.438 , de 26 de abril de 2.002

. Lei 10.762 , de 11 de novembro de 2.003

. Lei 12.212 , de 20 de janeiro de 2.010

. Manual de Operacionalização do Programa Luz para Todos, Revisão n ${ }^{\circ}$ 6, de

22 de fevereiro de 2009

Portaria $n^{\text {o }} 05$, de 5 de janeiro de 1990, DNAEE

Portaria $\mathrm{n}^{\mathrm{o}}$ 85, do Ministério de Minas e Energia

Projeto de Lei 1.921/1.999

BARROS, C. V. M. Reestruturação do setor elétrico e concorrência. Tese (Doutorado) - Faculdade de Direito, Universidade de São Paulo. 222 p. São Paulo, 2000

BETIOL Jr., G. Programa Luz para Todos em São Paulo: Planos de Obras Confrontados com a Prática das Distribuidoras, Visando Redução de Custos da Eletrificação Rural. São Paulo, 2005. Dissertação ( Mestrado) - Escola Politécnica da Universidade de São Paulo, São Paulo, 2005.

BETIOL, Jr. G.; STRAZZI, P. E.; RIBEIRO, F.S.; PAZZINI, L.H.A.; CARMO, J.R. Os padrões técnicos de engenharia aplicados aos programas de eletrificação rural implementados em São Paulo. In: CONGRESSO BRASILEIRO DE ENERGIA, $10 .$. CBE .Anais.. Rio de Janeiro: COPPE/UFRJ, 2004. v.4, p. $2.293-2.301$.

BORSTEIN, D. Como mudar o mundo: empreendedores sociais e o poder das novas idéias. Rio de Janeiro: Editora Record, 2005

BRANCO, C. Energia elétrica e capital estrangeiro no Brasil. São Paulo: Editora Alfa Ômega, 1.975 
CAMARGO, E.J.S. O estado, a prestação de serviços públicos no programa de eletrificação rural paulista $L u z$ da Terra e a violação dos direitos do consumidor. Dissertação (Mestrado em Direito). Universidade Metropolitana de Santos. UNIMES Santos, 2007

CAMARGO, E.J.S; RIBEIRO, F.S. Incorporação de aspectos do Programa Luz para Todos na regulação da ANEEL. In: LATIN AMERICAN CONGRESS: ELETRICITY AND TRANSMISSION, 8.2009, Ubatuba. CLAGTEE. Proceedings., 2009.

CAMARGO, E.J.S; RIBEIRO, F.S; GUERRA, S.M.G. O Programa Luz para Todos: metas e resultados. Revista Espaçoenergia, n.9, out.o 2009.

CARMO, J. R. do. Planejamento e operação de políticas públicas de eletrificação rural no Estado de São Paulo. 158p.Dissertação (Mestrado em energia) - Programa Interunidades de Pós-Graduação em Energia. São Paulo, 2005

CARMO, J. R.; Marques, R.M.B.S; Ribeiro, F.S. Universalization of Public Energy Services Case Study: The rural environment before and after the Law 10.438. In: Latin American Congress: Electricity Generation and Transmission, 5. São Pedro, 2003. Proceedings. 2003.. p.75.

COOPERS \& LYBRAND. Projeto de reestruturação do vetor elétrico brasileiro: cooperativas de eletrificação rural. Relatório VI-2. Ministério de Minas e Energia/Eletrobras. 1.997

CORREA, J.S.S. Eletrificação rural de baixo custo: avaliação e prática. 1992.Dissertação (Mestrado) - Escola Politécnica, Universidade de São Paulo. São Paulo, 1992.

ESMAP - Estratégias para eletrificação rural no Brasil - Workshop para discussão de opções. Ministério de Minas e Energia e The World Bank. 18 de junho de 2.002

FERNANDES JÚNIOR, A.G.F. Eletrificação rural : uso final da energia na produção de leite. 178p. Dissertação ( Mestrado em Engenharia )- Escola Politécnica da Universidade de São Paulo, São Paulo, 1999.

DEPARTAMENTO NACIONAL DE COOPERATIVISMO E DESENVOLVIMENTO RURAL, Ministério da Agricultura e Reforma Agrária, Programa Nacional de Eletrificação, Programa para o Banco Interamericano de Desenvolvimento. Relatório 
Preliminar, Brasil, 1991.

FIORILlO, C.A.P. Tutela Jurídica da Energia Vinculada ao Direito Ambiental Brasileiro. Saraivajur. Disponível em: <http://www.saraivajur.com.br/ doutrinaArtigosDetalhe.cfm?doutrina=961>. Acesso em: 30-10-2007.

FOLEY, G. Alternative institutional approaches to Rural Electrification In: RURAL ELECTRIFICATION GUIDEBOOK FOR ASIA AND PACIFIC. Bangkok: Asia Institute of Technology ,1.992

. Rural electrification in the developing world. Energy Policy, v. 20, n.1, p. 145-52, fev. 1992 (a).

FUGIMOTO, S.K A universalização do serviço de energia elétrica acesso e uso contínuo. Dissertação (Mestrado) - Escola Politécnica, Universidade de São Paulo. São Paulo, 2005

JUCÁ, A.S. Norma técnica para eletrificação rural. 1998. Dissertação (Mestrado) Escola Politécnica da Universidade de São Paulo. São Paulo, 1998.

O custo da regularização das cooperativas de eletrificação rural como permissionárias do serviço público de distribuição de energia elétrica. 2007. Monografia MBA Energia, Escola Politécnica da Universidade de São Paulo

Perspectivas para a regularização das cooperativas de eletrificação rural brasileiras In: CONGRESSO BRASILEIRO DE REGULAÇÃO DO SERVIÇO PÚBLICO CONCEDIDO,5., 2007. Recife. Anais. Recife, 2007

KURAHASSI, L.F. A eletrificação rural em São Paulo : custos e padrões. 2001. 90 p. Dissertação (Mestrado) - Escola Politécnica da Universidade de São Paulo. São Paulo, 2001.

LESSA, C. Eletrificação rural de baixo custo. Palestra proferida durante o Seminário de Utilização do CAZ. Porto Alegre, outubro de 1998.

MARQUES, R. M. B. S., Universalização do Atendimento: O Paradoxo da Exclusão dos Inadimplentes dos Programas de Eletrificação Rural Anteriores. São Paulo, 2005 Dissertação(Mestrado em Energia)- Programa Interunidades de Pós Graduação em Energia da Universidade de São Paulo, São Paulo, 2005. 
MUNASINGHE, M. Rural electrification for development: policy analysis and applications. Bouder. Colorado: Westview Press, 1987

NUNES, L.A.R. Curso de Direito do Consumidor. $4^{\text {a }}$ ed. São Paulo: Saraiva, 2004.

PAZZINI, L.H.A. Avaliação de uma política pública de eletrificação rural. São Paulo, 1998. Dissertação(Mestrado) - Escola Politécnica da Universidade de São Paulo, São Paulo, 1998

Eletrificação rural no novo cenário: o caso de São Paulo. 2001.

p.Tese (Doutorado) - Escola Politécnica, Universidade de São Paulo. São Paulo, 2001.

PELEGRINI, M.A. Prática de eletrificação rural em São Paulo (1995-1997). São Paulo, 1998. 134 f. Dissertação (Mestrado) - Escola Politécnica, Universidade de São Paulo. São Paulo, 1998.

As cooperativas de eletrificação rural no contexto da reforma do setor elétrico brasileiro. In: CONFERENCIA DE ELECTRIFICACIÓN RURAL, 18, 2001, San José, Costa Rica .. CLER. Anais. 2001

A regulação das cooperativas de eletrificação rural. São Paulo, 2003. Tese (Doutorado) - Escola Politécnica da Universidade de São Paulo, São Paulo, 2003

RIBEIRO, F. S. Eletrificação rural de baixo custo. São Paulo, 1993. Tese (livre docência) - Escola Politécnica da Universidade de São Paulo. São Paulo, 1993.

.O atendimento de produtores de baixa renda : um dilema institucional. In: CONFERÊNCIA LATINO-AMERICANA DE ELECTRIFICACIÓN RURAL, 14. 1993, Punta Del Este.. CLER. Anais. 1993. v. VIII.

A eletrificação rural ao alcance de todos In: Tecnologia e aplicação racional da energia elétrica e de fontes alternativas na agricultura/Ed. Oduvaldo José Seraphin, In: CONGRESSO BRASILEIRO DE ENGENHARIA AGRÍCOLA, 26., 1997, Campina Grande.. CONBEA . Anais. 1997

O pobre rural como objetivo explícito de uma política de eletrificação rural. XVI CONFERENCIA LATINO AMERICANA DE ELECTRIFICACIÓN RURAL , 16., Santiago, Chile. CLER Anais. 1997

Luz para Todos ou universalização do atendimento: como garantir a 
continuidade da inclusão social. Fortaleza : Agrener, 2008.

RIBEIRO, F.S.; CORREIA, J.S.S. Políticas brasileiras de eletrificação rural: a prática das concessionárias. In: REUNIÃO ANUAL DA SOCIEDADE BRASILEIRA PARA O PROGRESSO DA CIÊNCIA, 46, Vitória, 1994 Anais. São Paulo: SBPC, 1994.

RIBEIRO, T.B.S., A eletrificação rural com sistemas individuais de geração com fontes intermitentes em comunidades tradicionais: caracterização dos entraves para 0 desenvolvimento local, Dissertação (Mestrado)- Programa de Pós Graduação em Energia da Universidade de São Paulo, São Paulo, 2010. No prelo

SANTOS, J.F.M. Política de eletrificação rural. 1996. 161 p. Dissertação (Mestrado) - Universidade Federal do Rio de Janeiro. Rio de Janeiro, 1996.

SANTOS, R.H. Modelo 2004 : fundamentos, formulação e incertezas do setor elétrico. Tese (Doutorado) - Escola Politécnica da universidade de São Paulo, São Paulo, 2004

SAUER, I.L. et al. A Reconstrução do Setor Elétrico Brasileiro. São Paulo: Paz e Terra, 2003.

SAUNIER, G. ; MOHANTY, B. Overview and guidelines for Rural Electrification. In: RURAL ELECTRIFICATION GUIDEBOOK FOR ASIA AND PACIFIC. Bangkok, Asia Institute of Technology , 1992

SODRÉ, Nelson Werneck. A Coluna Prestes : análise e depoimentos. São Paulo: Círculo do Livro, 1997.

SOUZA, R.V. Retorno dos recursos públicos dos estados e Municípios aplicados em concessionárias privadas de energia elétrica: o caso do estado da Bahia. Dissertação (Mestrado) Universidade Salvador, Salvador , 2004

STRAZZI, P. Projeto de Uso Racional de Energia no Meio Rural: diagnóstico da eletrificação rural no Estado de São Paulo . São Paulo: Secretaria de Energia do Estado de São Paulo, 2001. $1^{\text {o }}$ Treinamento de Multiplicadores do Estado de São Paulo.

TENDRIH, L. Experiências com sistemas de eletrificação rural de baixo custo: uma análise dos impactos sócio-econômicos. 1990. 171 p. Dissertação (Mestrado) - Instituto 
de Ciências Humanas e Sociais, curso de pós-graduação em desenvolvimento agrícola da Universidade Federal Rural do Rio de Janeiro. Itaguaí, Rio de Janeiro, 1990.

TOURINHO, R. Luz no Campo é cidadania para a população rural. Correio da Bahia. Disponível em: http://www.mme.gov.br/noticias/luznocampo.htm Acesso em : 14 ago.2006.

STRAZZI, Paulo Ernesto. Desenvolvimento social e programas de eletrificação rural de não atendidos.São Paulo, 2009. Tese (Doutorado) - Programa de Pós Graduação em Energia da Universidade de São Paulo., São Paulo, 2009.

YOSHINO, S; RIBEIRO, F.S.; RIBEIRO, T.B.S. O processo de implantação doPrograma Luz para Todos em Ubatuba, São Paulo. In: LATIN-AMERICAN CONGRESS ON ELECTRICITY GENERATION AND TRANSMISSION, 8. , 2009. Ubatuba.. . CLAGTEE. Proceedings. Guaratingueta: FEG/UNESP, 2009. 